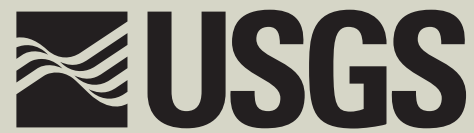

science for a changing world

Studies by the U.S. Geological Survey in Alaska, Volume 15

\title{
Upper Cretaceous and Lower Jurassic Strata in Shallow Cores on the Chukchi Shelf, Arctic Alaska
}

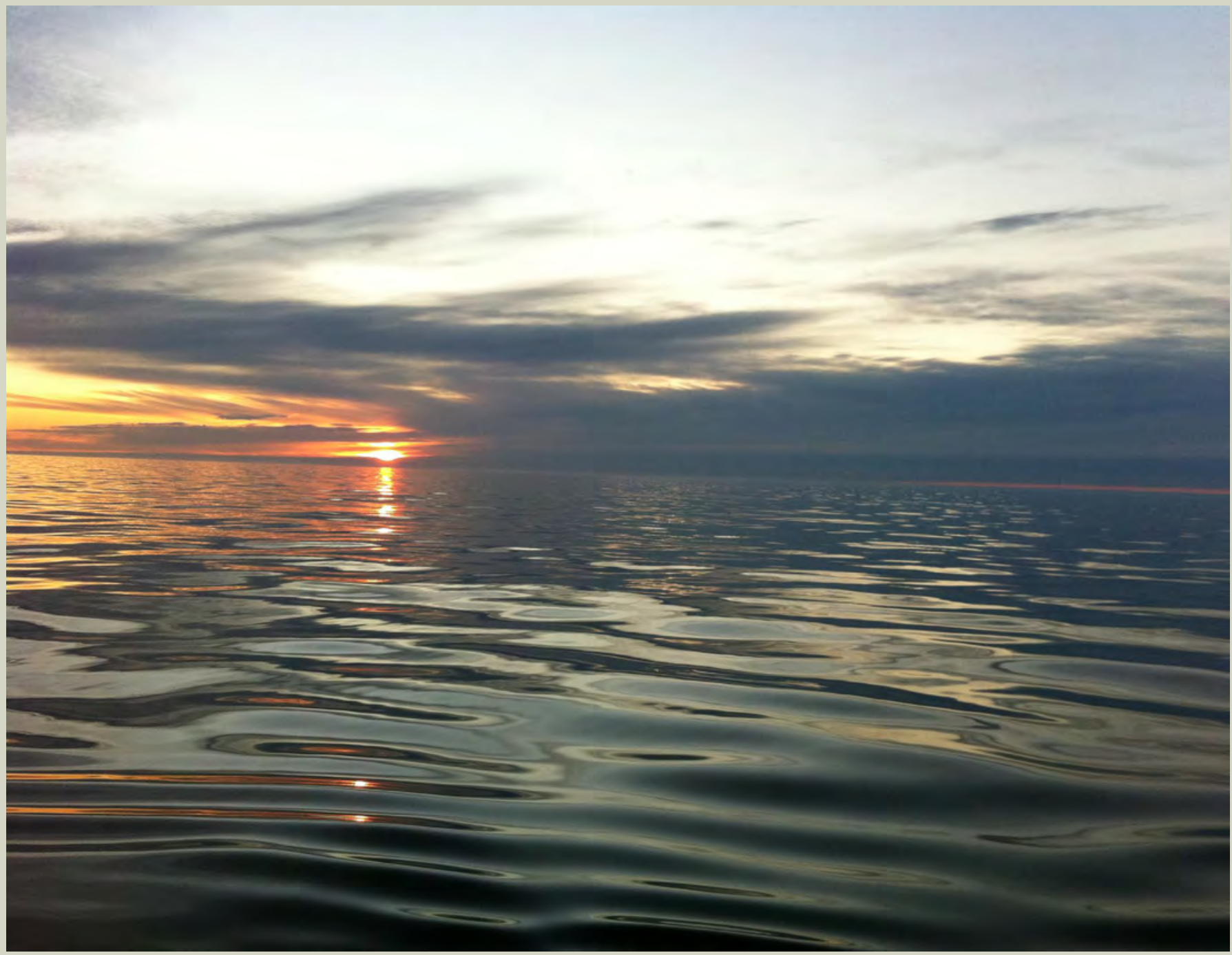

Professional Paper 1814-C 
Cover. Photograph of sunset over the Chukchi Sea, Alaska, September 2011 (photograph courtesy of Professor Bernard Coakley, University of Alaska Fairbanks). 


\section{Upper Cretaceous and Lower Jurassic Strata in Shallow Cores on the Chukchi Shelf, Arctic Alaska}

By David W. Houseknecht, William H. Craddock, and Richard O. Lease

Professional Paper 1814-C 


\title{
U.S. Department of the Interior SALLY JEWELL, Secretary
}

\section{U.S. Geological Survey Suzette M. Kimball, Director}

\author{
U.S. Geological Survey, Reston, Virginia: 2016
}

For more information on the USGS - the Federal source for science about the Earth, its natural and living resources, natural hazards, and the environment-visit http://www.usgs.gov/ or call 1-888-ASK-USGS (1-888-275-8747).

For an overview of USGS information products, including maps, imagery, and publications, visit http://www.usgs.gov/pubprod/.

Any use of trade, firm, or product names is for descriptive purposes only and does not imply endorsement by the U.S. Government.

Although this information product, for the most part, is in the public domain, it also may contain copyrighted materials as noted in the text. Permission to reproduce copyrighted items must be secured from the copyright owner.

Suggested citation:

Houseknecht, D.W., Craddock, W.H., and Lease, R.0., 2016, Upper Cretaceous and Lower Jurassic strata in shallow cores on the Chukchi Shelf, Arctic Alaska, in Dumoulin, J.A., ed., Studies by the U.S. Geological Survey in Alaska, vol. 15: U.S. Geological Survey Professional Paper 1814-C, 37 p., http://dx.doi.org/10.3133/pp1814C. 


\section{Acknowledgments}

The work summarized in this report was supported in part by Statoil. Personnel in the U.S. Geological Survey (USGS) Pacific Coastal and Marine Science Center, including Mike Torresan, Cathy Frazee, Brian Edwards, Angela Lam, Pat Hart, Carolyn Degnan, Carol Reiss, and Jon Childs, facilitated core description and sampling and compilation and digitization of single-channel seismic data. Natalie Stier (USGS Eastern Energy Resources Science Center) converted the digitized seismic data to SEG-Y format and loaded the data into computer workstations. Peter Flaig and Dolores van der Kolk (University of Texas at Austin Bureau of Economic Geology), Ken Bird (USGS retired), and Julie Dumoulin (USGS volume editor) provided reviews that improved the report. 


\section{Contents}

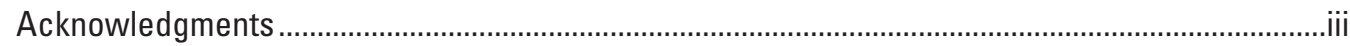

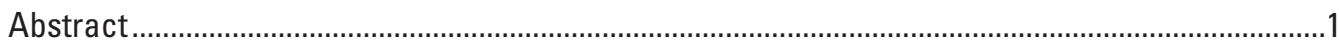

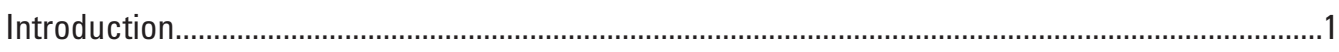

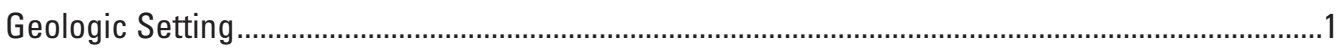

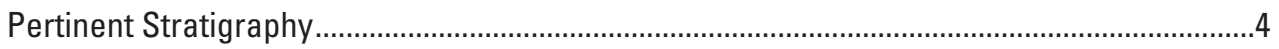

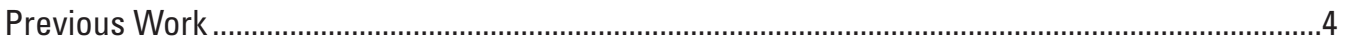

Methods

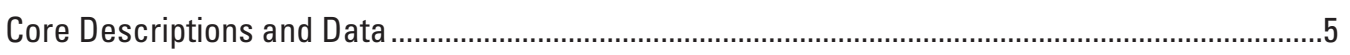

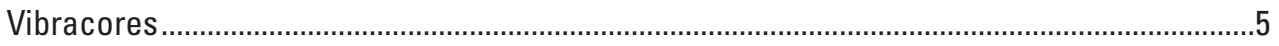

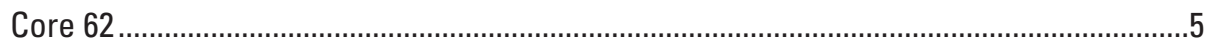

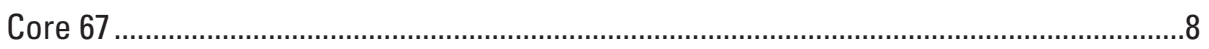

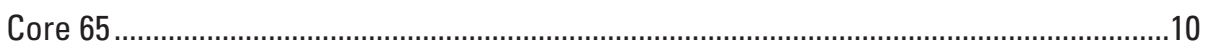

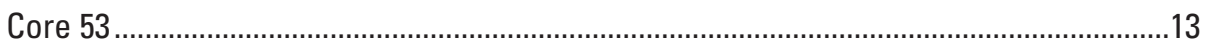

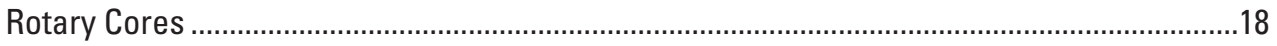

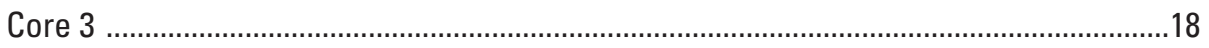

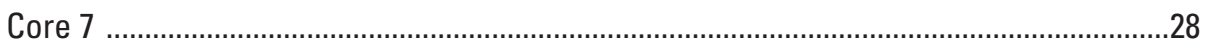

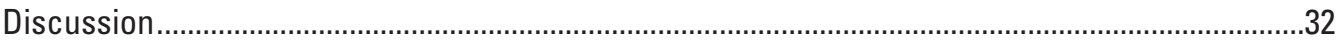

Herald Arch Foreland —Cores C3, C53, C65, C67, and C62...............................................32

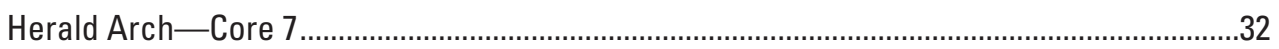

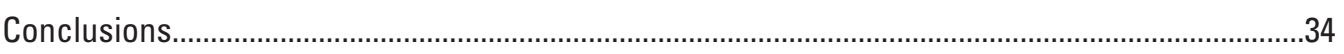

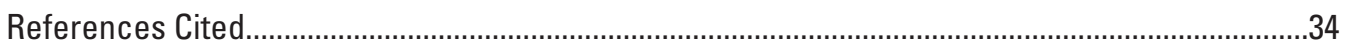

\section{Figures}

1. Map of Arctic Alaska and the Chukchi Shelf showing main tectonic elements and locations

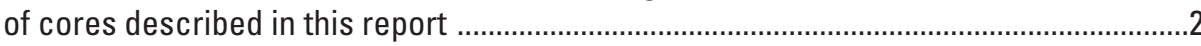

2. Diagram showing generalized chronostratigraphy of the Chukchi Shelf, Alaska ......................

3. Seismic image across the location of U.S. Geological Survey vibracore C62, Chukchi Shelf, Alaska...

4. Graphic section and composite photograph of U.S. Geological Survey vibracore C62, Chukchi Shelf, Alaska

5. Seismic image across the location of U.S. Geological Survey vibracore C67, Chukchi Shelf, Alaska

6. Graphic section and composite photograph of U.S. Geological Survey vibracore C67, Chukchi Shelf, Alaska

7. Seismic image across the location of U.S. Geological Survey vibracore C65, Chukchi Shelf, Alaska

8. Graphic section and composite photograph of U.S. Geological Survey vibracore C65, Chukchi Shelf, Alaska

9. Graph showing age probability plots from argon-40/argon-39 single-crystal laser-fusion analyses of sanidine grains from U.S. Geological Survey vibracore C65 tephra samples S35, S36, and S37 
10. Seismic image across the location of U.S. Geological Survey vibracore C53, Chukchi Shelf,

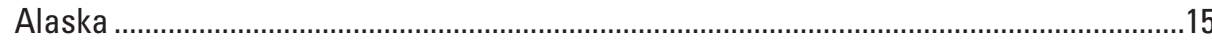

11. Graphic section and composite photograph of U.S. Geological Survey vibracore C53, Chukchi Shelf, Alaska .................................................................................................................16

12. Detrital zircon uranium/lead (U/Pb) age data for three sandstone samples from shallow cores on the Chukchi Shelf, Alaska ..................................................................................17

13. Composite photograph of U.S. Geological Survey cores from the Chukchi Shelf, Alaska, showing examples of damage induced by rotary coring .................................................19

14. Seismic image across the location of U.S. Geological Survey rotary core C3, Chukchi Shelf,

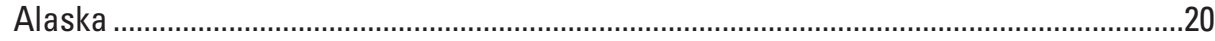

15. Graphic section of U.S. Geological Survey rotary core C3, Chukchi Shelf, Alaska ...............20

16. Composite photographs of U.S. Geological Survey rotary core C3, Chukchi Shelf, Alaska ..22

17. Diagrams of age spectra from argon-40/argon-39 dating of six single crystals of biotite from U.S. Geological Survey rotary core C3 tuffaceous mudstone sample S12, Chukchi Shelf, Alaska ................................................................................................................27

18. Seismic image across the location of U.S. Geological Survey rotary core C7, Chukchi Shelf,

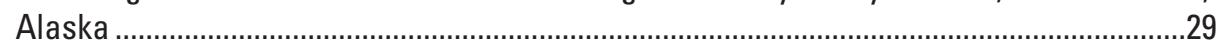

19. Graphic section of U.S. Geological Survey rotary core 7C, Chukchi Shelf, Alaska ...............30

20. Photographs of U.S. Geological Survey rotary core C7, Chukchi Shelf, Alaska ....................31

\section{Tables}

1. Total organic carbon and Rock-Eval data and summary of vitrinite and bitumen reflectance data and of optical observations for samples from U.S. Geological Survey rotary cores C3 and C7, Chukchi Shelf, Alaska

2. Summary of age constraints indicating the presence of Upper Cretaceous and older strata, and evidence for recycled palynomorphs in shallow cores from the Chukchi Shelf, Alaska 



\title{
Upper Cretaceous and Lower Jurassic Strata in Shallow Cores on the Chukchi Shelf, Arctic Alaska
}

\author{
By David W. Houseknecht, William H. Craddock, and Richard O. Lease
}

\section{Abstract}

Shallow cores collected in the 1980s on the Chukchi Shelf of western Arctic Alaska sampled pre-Cenozoic strata whose presence, age, and character are poorly known across the region. Five cores from the Herald Arch foreland contain Cenomanian to Coniacian strata, as documented by biostratigraphy, geochronology, and thermochronology. Shallow seismic reflection data collected during the 1970s and 1980s show that these Upper Cretaceous strata are truncated near the seafloor by subtle angular unconformities, including the Paleogene mid-Brookian unconformity in one core and the Pliocene-Pleistocene unconformity in four cores. Sedimentary structures and lithofacies suggest that Upper Cretaceous strata were deposited in a low accommodation setting that ranged from low-lying coastal plain (nonmarine) to muddy, shallowmarine environments near shore. These observations, together with sparse evidence from the adjacent western North Slope, suggest that Upper Cretaceous strata likely were deposited across all of Arctic Alaska.

A sixth core from the Herald Arch contains lower Toarcian marine strata, indicated by biostratigraphy, truncated by a Neogene or younger unconformity. These Lower Jurassic strata evidently were deposited south of the arch, buried structurally to high levels of thermal maturity during the Early Cretaceous, and uplifted on the Herald thrust-fault system during the mid to Late Cretaceous. These interpretations are based on regional stratigraphy and apatite fission-track data reported in a complementary report and are corroborated by the presence of recycled palynomorphs of Early Jurassic age and high thermal maturity found in Upper Cretaceous strata in two of the foreland cores. This dataset provides evidence that uplift and exhumation of the Herald thrust belt provided sediment to the foreland during the Late Cretaceous.

\section{Introduction}

Between 1977 and 1985, the U.S. Geological Survey (USGS) conducted marine cruises on the shelf of the Alaska Chukchi Sea to investigate geological characteristics of the seafloor and shallow subsurface. Two of those cruises included the collection of cores that penetrated pre-Cenozoic bedrock, which locally occurs beneath the regional midBrookian (Paleogene) unconformity or one of several younger unconformities at shallow depth below the seafloor (fig. 1). Despite the importance of those strata for understanding the regional geologic framework, little information has been published regarding the pre-Cenozoic bedrock sampled by that coring. The objectives of this report are to describe the pre-Cenozoic strata sampled by those cores; present results of biostratigraphic and radiometric dating, and of organic petrologic and thermal maturity analyses; and interpret the age and depositional environments of those strata.

\section{Geologic Setting}

The Chukchi Shelf contains a stratigraphic succession similar to that of the Alaska North Slope (fig. 2). Acoustic basement is presumed to consist of metasedimentary rocks, which were deformed regionally during the Devonian Ellesmerian orogeny and that locally display relict stratigraphy in seismic reflection data (Sherwood, 1994; Kumar and others, 2011). Younger tectonic elements include the Hanna Trough, an Upper Devonian(?) to Triassic, north-south-trending graben system flanked by high-standing blocks of acoustic basement (Sherwood and others, 2002; Houseknecht and Connors, 2015; fig. 1). The Chukchi Platform on the west was a persistent high as evidenced by thinning and onlap of Upper Devonian through Cretaceous strata. The Arctic Platform on the east similarly persisted as a high-standing block following the Ellesmerian orogeny and likely was uplifted further during rift opening of the Canada Basin (Houseknecht and Bird, 2011; Craddock and Houseknecht, 2016). These Paleozoic to lowermost Cretaceous geologic elements of the Chukchi Shelf are overprinted by the Wrangel-Herald Arch thrust belt, which is exposed on Wrangel Island of Russia and in the Lisburne Hills of northwestern Alaska (Grantz and others, 1975; Moore and others, 2002; fig. 1). Wrangel Island displays generally north-vergent contractional deformation and the Lisburne Hills displays generally northeast-vergent contractional deformation, both of which occurred during the Early Cretaceous (Kos'ko and others, 1993; Moore and others, 2002). The Wrangel-Herald Arch thrust belt is the relict northern leading edge of the Chukotka orogen. The thrust belt is overprinted by the South Chukchi-Hope successor basin, which is bounded by Cenozoic transtensional faults and filled with Eocene and younger strata (Tolson, 1987; Klemperer and others, 2002; Verzhbitsky and others, 2012). 


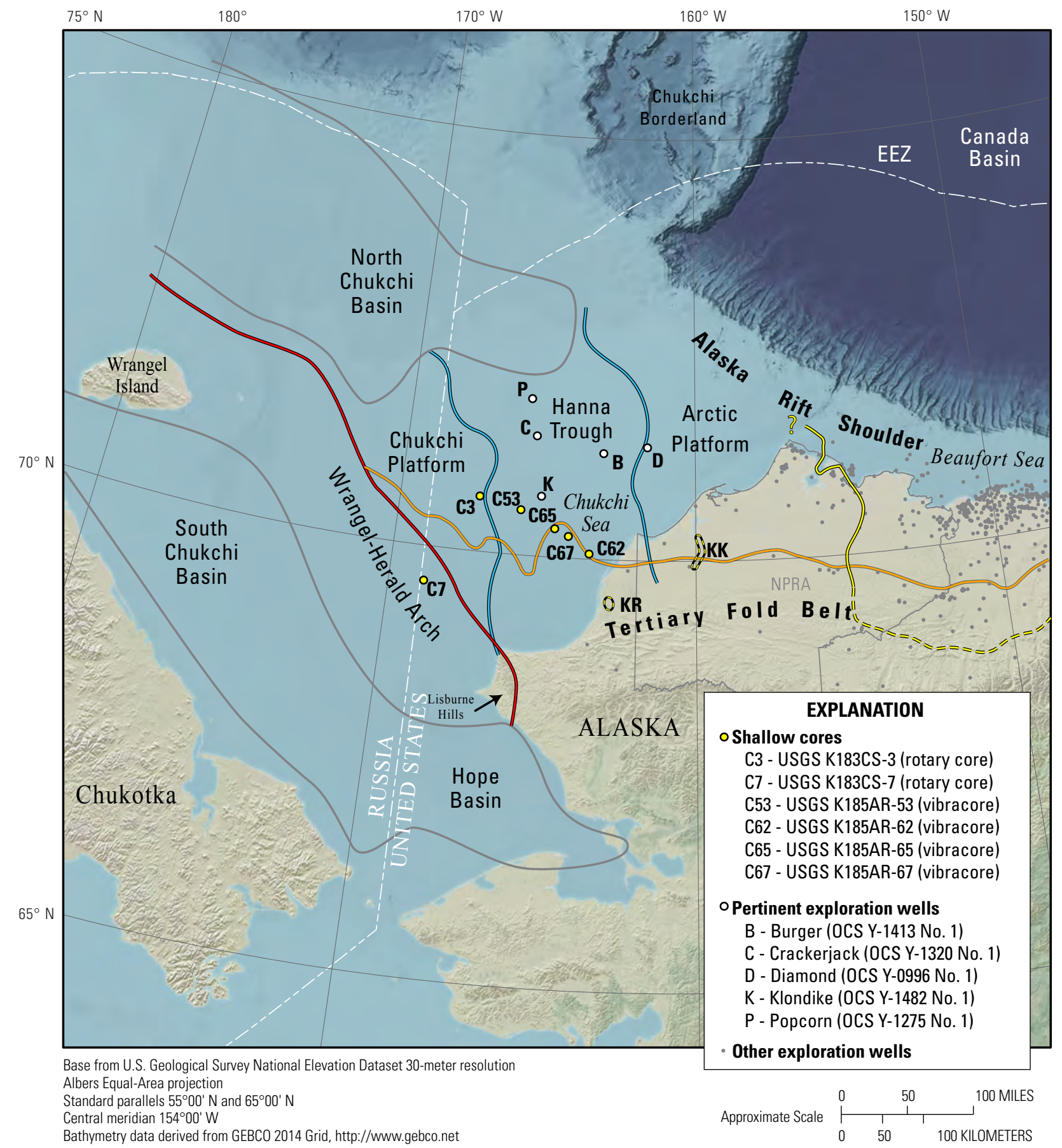

Figure 1. Map of Arctic Alaska and the Chukchi Shelf showing main tectonic elements and locations of cores described in this report. Also shown are truncation edge of Upper Cretaceous strata (yellow line, long dashes where generalized) in eastern National Petroleum Reserve in Alaska (NPRA), and areas along the Kuk and Kaolak Rivers (yellow line with short dashes labeled KK) and along the Kukpowruk River (yellow line with short dashes labeled KR) where the presence of Upper Cretaceous strata has been inferred on the basis of paleobotany and the presence of tephra. Margins of North Chukchi and South Chukchi-Hope Basins shown in gray; margins of Hanna Trough shown in blue, northern limit of Wrangel-Herald Arch (including surface trace of Herald thrust fault) shown in red, and northern limit of Cenozoic fold belt shown in orange. Boundaries of Exclusive Economic Zone (EEZ) shown in white. 


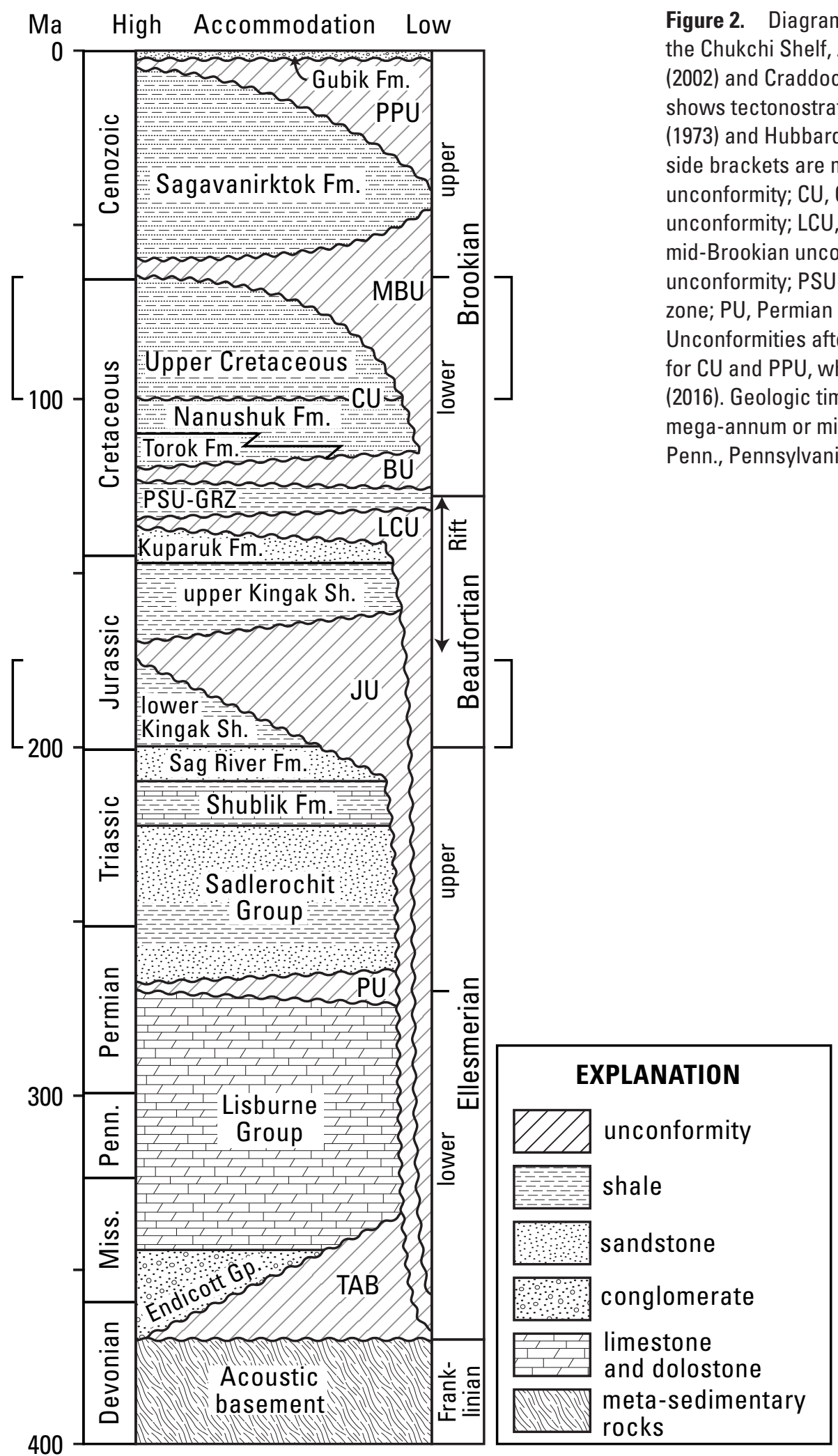


The South Chukchi-Hope Basin is flanked to the southwest by the Chukotka Peninsula of Russia (fig. 1), which includes the interior of the Chukotkan orogen and volcanic centers that were active during the Cretaceous and Cenozoic (Garver and others, 2000; Stone and others, 2009; Akinin and Miller, 2011; Tikhomirov and others, 2012). Widespread airfall tephra in Upper Cretaceous strata across Arctic Alaska has been attributed to the Chukotka volcanic centers (Bergman and others, 2006; Houseknecht and Bird, 2011). Ongoing detrital zircon uranium/lead $(\mathrm{U} / \mathrm{Pb})$ dating of Cretaceous and younger sandstone samples from Arctic Alaska indicates that a young zircon $\mathrm{U} / \mathrm{Pb}$ age population can be correlated to coeval Chukotka volcanism (Lease and others, 2014).

\section{Pertinent Stratigraphy}

Despite similarities to that of the Alaska North Slope, Chukchi stratigraphy is known in less detail because no exposures are present, and only five widely spaced petroleum exploration wells have been drilled (fig. 1). Those wells are positioned on structurally high, low-accommodation geologic features and therefore have not penetrated certain stratigraphic intervals inferred to be present on the basis of seismicreflection data and known from well penetrations onshore (Sherwood and others, 2002).

Two parts of the stratigraphy pertinent to this report, and not penetrated by offshore exploration wells, are described here. The Lower Jurassic lower Kingak Shale is known from outcrops in the Brooks Range foothills and subsurface penetrations on the Alaska North Slope (Houseknecht and Bird, 2004). This unit is thought to be present in high accommodation areas of the Chukchi Shelf (for example, in Hanna Trough grabens; Sherwood and others, 2002) based on seismic reflection data. Lower Jurassic strata are present in one shallow core described in this report.

The youngest Cretaceous strata penetrated by Chukchi exploration wells are assigned to the Lower Cretaceous Nanushuk Formation (fig. 2), although the possible presence on the Chukchi Shelf of the Upper Cretaceous Colville Group was recognized by Sherwood and others (2002). A revision of Upper Cretaceous stratigraphic nomenclature for northern Alaska (Mull and others, 2003) abandoned the Colville Group and assigned Upper Cretaceous strata to the Seabee, Tuluvak, Schrader Bluff, and Prince Creek Formations (ascending order). Upper Cretaceous strata are included in multiple shallow cores described in this report. However, their age and lithofacies are insufficient to assign them to Upper Cretaceous formations recognized onshore. Therefore, we refer to them informally as "Upper Cretaceous strata" (fig. 2).

\section{Previous Work}

The cores described in this report were collected during USGS cruises in 1983 (Winters and Lee, 1985) and
1985 (Miley and Barnes, 1986; Phillips and Colgan, 1987). Coring locations were selected based mainly on geological features revealed by single channel, high resolution, shallow seismic reflection (uniboom) data collected during the same or previous cruises (for example, Phillips and Colgan, 1987; Phillips and others, 1988). Descriptions and analyses of rotary cores collected in 1983 are limited to a report on geotechnical properties (Winters and Lee, 1985). Quaternary strata in vibracores collected in 1985 have been a focus of published reports on the environment and paleoecology of the Bering land bridge (Elias, 2000; Elias and others, 1992, 1996, 1997), but little work has been focused on older strata. Phillips and Colgan (1987) reported the presence of tephra and "consolidated silt and clay" in some of the vibracores. Phillips and others (1988) reported stratigraphically ordered potassium-argon (K-Ar) dates from biotite of 95 and 92 Ma from a laminated sandstone in core 67 (fig. 1). They concluded that the biotite was reworked from a nearby source, presumably volcanic, and that the tephra-bearing strata in five of the cores likely are of Late Cretaceous age. A cross section depicting the relation of the tephra-bearing Cretaceous strata to younger deposits is included in Elias and others (1992). A revised version of the published cross section and additional $\mathrm{K}-\mathrm{Ar}$ dates (ranging from Cenomanian to Campanian) from tephra in five cores were provided to us more recently as unpublished material (R. Phillips, 2002, written commun.). However, some of the K-Ar dates are not stratigraphically ordered, and neither the analyses nor the original sample material could be located. Therefore, we considered those dates as a general indication of tephra ages but do not include the absolute dates in this report.

\section{Methods}

Rotary cores from the 1983 cruise and vibracores from the 1985 cruise were described, photographed, and sampled in the refrigerated USGS Marine Sample Repository in Menlo Park, California. Description and sampling were focused mainly on sub-Quaternary strata. Samples were collected for a variety of analyses, including biostratigraphy, petroleum source-rock evaluation, thermal maturity, geochronology, and thermochronology. Some samples from rotary cores were hand-picked and (or) cleaned ultrasonically in distilled water because of coring damage, which is described in a subsequent section. Where possible, samples were collected from the center of the core to avoid mud infiltration (rotary cores) and drag-induced distortion and mixing (vibracores).

Biostratigraphic analyses of shale and mudstone samples were conducted by consultants Jonathan Bujak (palynology) and Paul Connell (foraminifera), with palynological analysis being done for all samples and foraminifera micropaleontology being done on selected samples. Total organic carbon (TOC) and Rock-Eval pyrolysis analyses of selected shale and mudstone samples were performed by 
Weatherford Laboratories, and vitrinite reflectance analysis was performed by Mark Pawlewicz and Paul Hackley (USGS). Dating of tephra and selected tuffaceous mudstone and sandstone samples was attempted using argon-40/argon$39\left({ }^{40} \mathrm{Ar} /{ }^{39} \mathrm{Ar}\right)$ geochronology for potassium-bearing target minerals (sanidine and biotite) by Matthew Heizler of the New Mexico Geochronology Research Laboratory. Argon from sanidine was extracted by single crystal laser fusion whereas individual biotite crystals were step-heated using a defocused carbon dioxide $\left(\mathrm{CO}_{2}\right)$ laser. Detailed descriptions of laboratory methods and instrumentation can be found at https://geoinfo. nmt.edu/labs/argon/home.html.

Detrital zircon $\mathrm{U} / \mathrm{Pb}$ dating of selected sandstone samples was conducted by Richard Lease (USGS) at the University of California at Santa Barbara using a laser-ablation multicollector, inductively coupled plasma mass spectrometer (LA-MC-ICPMS), following "conventional" detrital zircon methods described in Cottle and others (2012). We report ${ }^{206} \mathrm{~Pb} /{ }^{238} \mathrm{U}$ dates for grains younger than $1,000 \mathrm{Ma}$ (megaannum or millions of years ago) and ${ }^{206} \mathrm{~Pb} /{ }^{207} \mathrm{~Pb}$ dates for grains older than 1,000 Ma. We discarded grains older than $500 \mathrm{Ma}$ that were greater than 20 percent normally discordant $\left(\left(1-\left({ }^{206} \mathrm{~Pb} /{ }^{238} \mathrm{U}\right.\right.\right.$ date $) /\left({ }^{206} \mathrm{~Pb} /{ }^{207} \mathrm{~Pb}\right.$ date $\left.\left.)\right)>0.20\right)$ or 5 percent reversely discordant $\left(\left(1-\left({ }^{206} \mathrm{~Pb} /{ }^{238} \mathrm{U}\right.\right.\right.$ date $) /\left({ }^{206} \mathrm{~Pb} /{ }^{207} \mathrm{~Pb}\right.$ date $\left.)\right)$ $<-0.05)$. Maximum depositional ages were estimated by calculating the weighted mean of the youngest distinct population of $\mathrm{U} / \mathrm{Pb}$ dates.

Apatite fission-track (AFT) ages $(n \sim 40)$ and lengths $(n \sim 200)$ of selected sandstone samples were measured by Paul O'Sullivan of Apatite to Zircon, Inc., using the optical and laser ablation, inductively coupled plasma mass spectrometry methods described by Donelick and others (2005). More detailed description of the AFT methods and results can be found in Craddock and Houseknecht (2016). We use the geologic time scale of Walker and others (2013) for correlating absolute dates and ages.

USGS marine cruises on the Chukchi Shelf between 1977 and 1985 included the collection of single-channel, highresolution shallow seismic-reflection data saved as hardcopy records during each cruise. Archived records were scanned, converted to digital format (SEG-Y) using software available from the Geological Survey of Canada (Courtney, 2012), and imported into a seismic workstation. We correlated cores with the shallow seismic data, and subsequently correlated the shallow seismic data with deeper multichannel seismic data to interpret the placement of the cores into a regional stratigraphic framework.

\section{Core Descriptions and Data}

\section{Vibracores}

Four well-preserved vibracores containing inferred Cretaceous strata are included in this study (fig. 1; C53, C62,
C65, and C67). A fifth core, located between C53 and C65 (fig. 1) and reported to contain tephra at the base of the core (Phillips and Colgan, 1987), was examined, and no tephra was found. The vibracores are well preserved and display primary sedimentary structures, although bedding is distorted at the core margins, likely the result of drag induced by the vibracoring process. Inferred Cretaceous strata are poorly to moderately consolidated and younger strata are mainly poorly consolidated to unconsolidated. General descriptions of the vibracores follow, presented from east (nearshore) to west (fig. 1). An image of shallow seismic data is included to provide an outcrop-scale perspective of each core location. Geochronology and other analytical results are included with the core descriptions to establish the age of lithostratigraphic units.

\section{Core 62}

Core 62 is located on the north flank of a west-plunging anticline in Cretaceous strata, which are truncated by a nearly horizontal Pliocene-Pleistocene unconformity (PPU; fig. 3). Cretaceous strata display apparent dip of $1-2^{\circ}$ north at the core location, and small displacement normal faults dip both north and south nearby (fig. 3).

The bottom of $\mathrm{C} 62$ consists of 53 centimeters $(\mathrm{cm})$ of pale greenish gray to white tephra (fig. 4, unit C62-a), which displays irregular, approximately horizontal laminae defined by variable concentrations of volcanic glass and clay. The diagenetic clay formed from alteration of volcanic material, as determined by Phillips and Colgan (1987). Biotite crystals and white crystals of quartz or sanidine are visible locally. However, a sample of the tephra submitted for ${ }^{40} \mathrm{Ar} /{ }^{39} \mathrm{Ar}$ dating did not yield datable minerals (fig. 4). Neither the laminae nor the clean, pristine clay minerals appear to be deposits of waterborne, suspended sediment, and we suggest that the irregular laminae resulted from settling of inhomogeneous components of volcanic ash, subsequently modified by diagenesis. Despite the lack of datable minerals, we interpret this tephra as Late Cretaceous in age on the basis of age determinations from similar tephra in nearby cores (see below) and the regional abundance of tephra in Upper Cretaceous strata. We interpret this tephra as air-fall volcanic ash deposited on land, because it lacks clear indications of deposition in water.

The top of the tephra is in sharp contact with an overlying, mainly fine to very fine grained, grayish tan, 2.0-meter-thick sandstone with a few thin, muddy intervals (fig. 4, unit C62-b). The sandstone is locally pebbly, especially near the middle (fig. 4). No sedimentary structures are visible, and the sandstone is irregularly iron stained throughout.

Although concentration of iron staining along fractures may suggest a postcoring origin, the stain was reported as primary by Phillips and Colgan (1987). This sandstone was interpreted as nonmarine by Phillips and Colgan (1987) and correlated to a stratigraphic unit found to be of Pleistocene age by Elias and others (1992). We concur with the nonmarine interpretation 


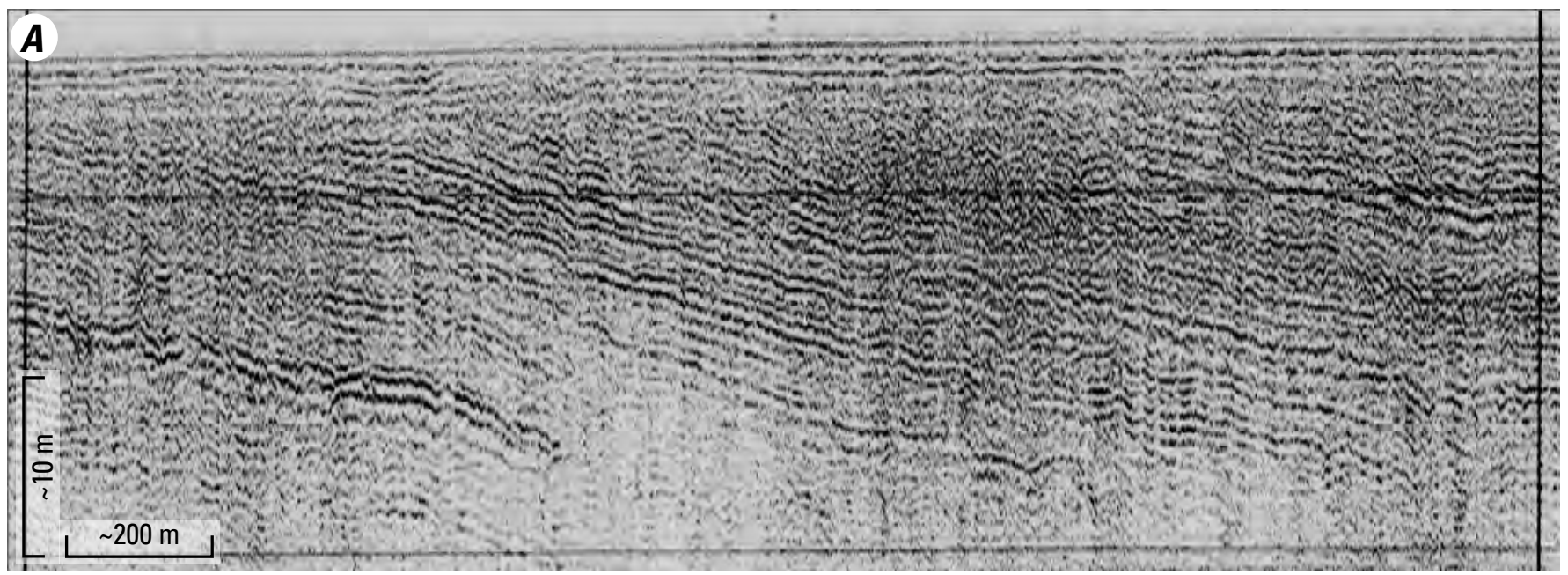

Vertical exaggeration $\sim 25 x$

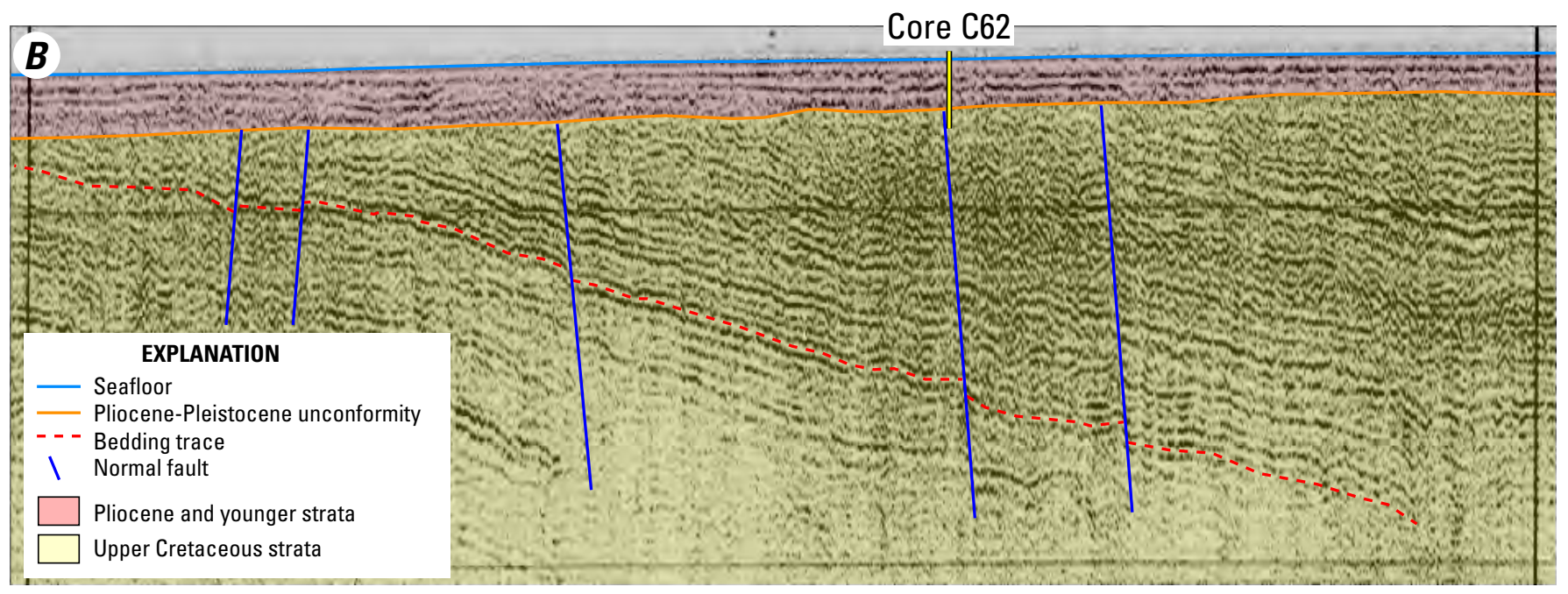

Figure 3. Seismic image across the location of U.S. Geological Survey vibracore C62, Chukchi Shelf, Alaska. Uninterpreted $(A)$ and interpreted $(B)$ uniboom seismic image illustrating Upper Cretaceous strata displaying apparent dip of $1-2^{\circ}$ north truncated by nearly horizontal Pliocene-Pleistocene unconformity. Bedding trace may not be drawn on single stratum but indicates relative offset across normal faults. See figure 1 for core location. m, meters. 
Vibracore D185AR-62

Location: $70.08670^{\circ} \mathrm{N} ; 163.58670^{\circ} \mathrm{W}$

Water depth: $30.5 \mathrm{~m}(100.1 \mathrm{ft})$

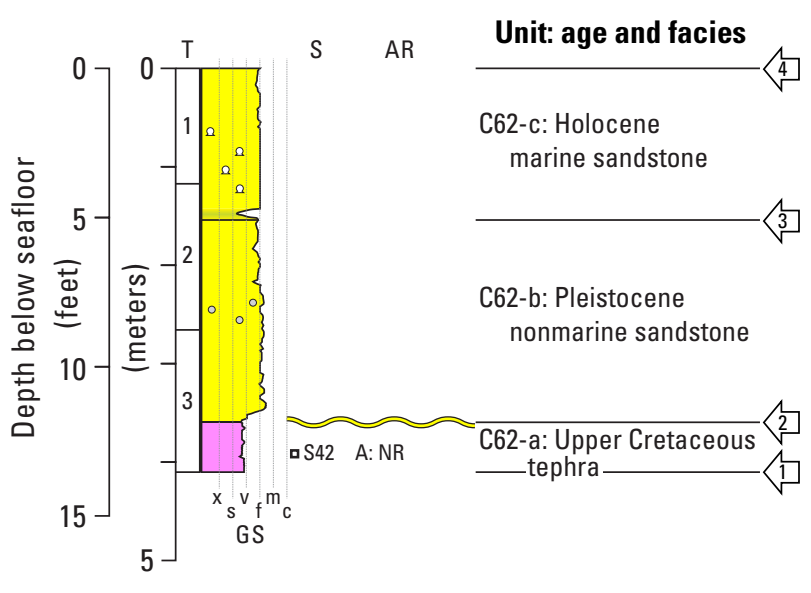

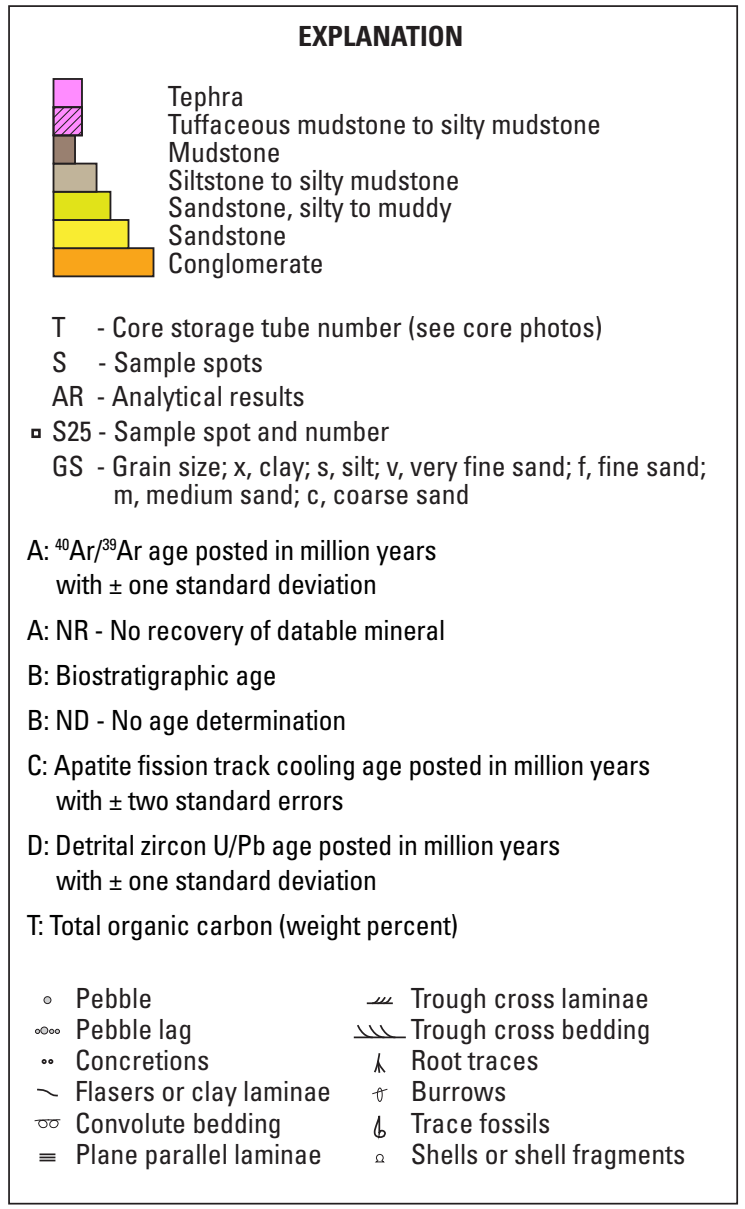

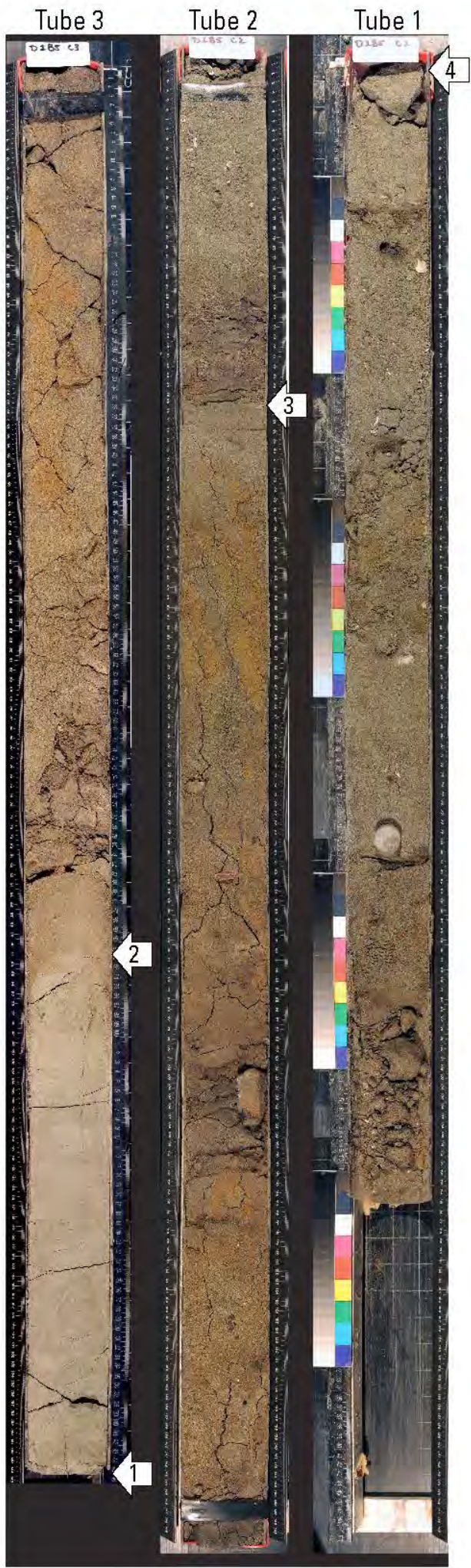

Figure 4. Graphic section and composite photograph of U.S. Geological Survey vibracore C62, Chukchi Shelf, Alaska. Top of Upper Cretaceous strata indicated by yellow and black unconformity symbol. Numbered arrows correlate spots in graphic section to correlative spots in core photograph. Cores are stored in plexiglass half-tubes. See figure 1 for core location. Note that explanation applies to all related figures in this report. Scales on photograph are in centimeters. $\mathrm{ft}$, feet; $\mathrm{m}$, meters; ${ }^{40} \mathrm{Ar} /{ }^{39} \mathrm{Ar}$, argon-40/argon-39. 
and emphasize that the basal contact with the tephra is an unconformity.

The iron-stained sandstone is overlain by a 9 -cm-thick, red-brown stained sandy mudstone, which is overlain by 1.5 meters $(\mathrm{m})$ of fine grained, greenish gray sandstone with common bivalve fragments (fig. 4, unit C62-c). This interval was interpreted as marine by Phillips and Colgan (1987), and found to be of Holocene age by Elias and others (1992). We accept these previous interpretations.

\section{Core 67}

Core 67 is located near the axis of the same westplunging anticline as core 62 . The anticline involves Cretaceous strata, which are truncated by a nearly horizontal PPU (fig. 5). Cretaceous strata display apparent dip of less than $0.5^{\circ}$ west at the core location, and small displacement normal faults dip both west and east nearby (fig. 5).

The lower $1.4 \mathrm{~m}$ of $\mathrm{C} 67$ consists of sandstone that fines upward to sandy tephra (fig. 6, unit C67-a). The lower $60 \mathrm{~cm}$ of sandstone is fine grained and ranges from greenish brown to greenish gray in color, with scattered biotite-rich laminae each about 1 millimeter (mm) thick (fig. 6). The upper $8 \mathrm{~cm}$ of the sandstone is visibly coarser, although still fine grained. The overlying $20 \mathrm{~cm}$ grades from brown to dark gray sandstone upward into tan to light gray, sandy tephra. This gradation consists of thin interbeds of tuffaceous sandstone and sandy tephra, with the proportion of sandstone decreasing and the proportion of tephra increasing upward. The upper $60 \mathrm{~cm}$ of this unit is mainly tephra with thin (3 to $10 \mathrm{~mm}$ ) and diffuse sandstone interbeds. The tephra ranges from tan to greenish gray to white, and the sandstone is mainly brown. Phillips and others (1988) reported that the sandstone contains "white and

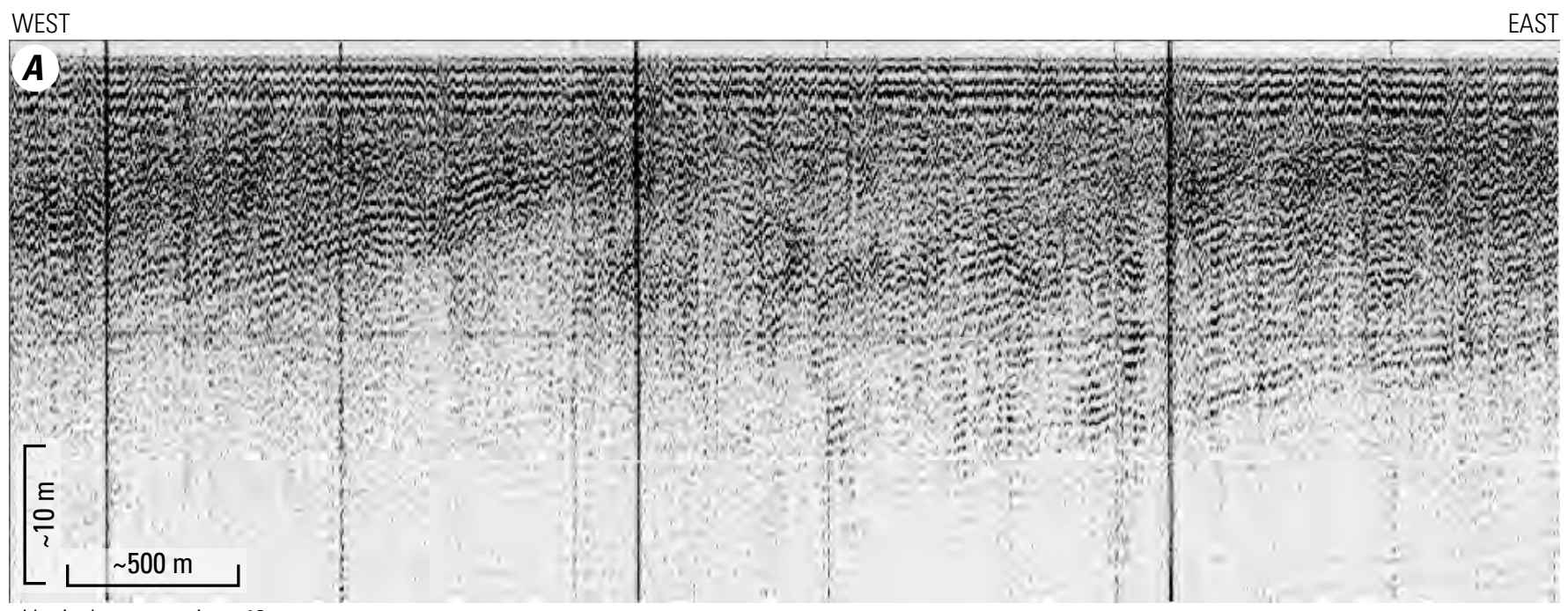

Vertical exaggeration $\sim 40 x$

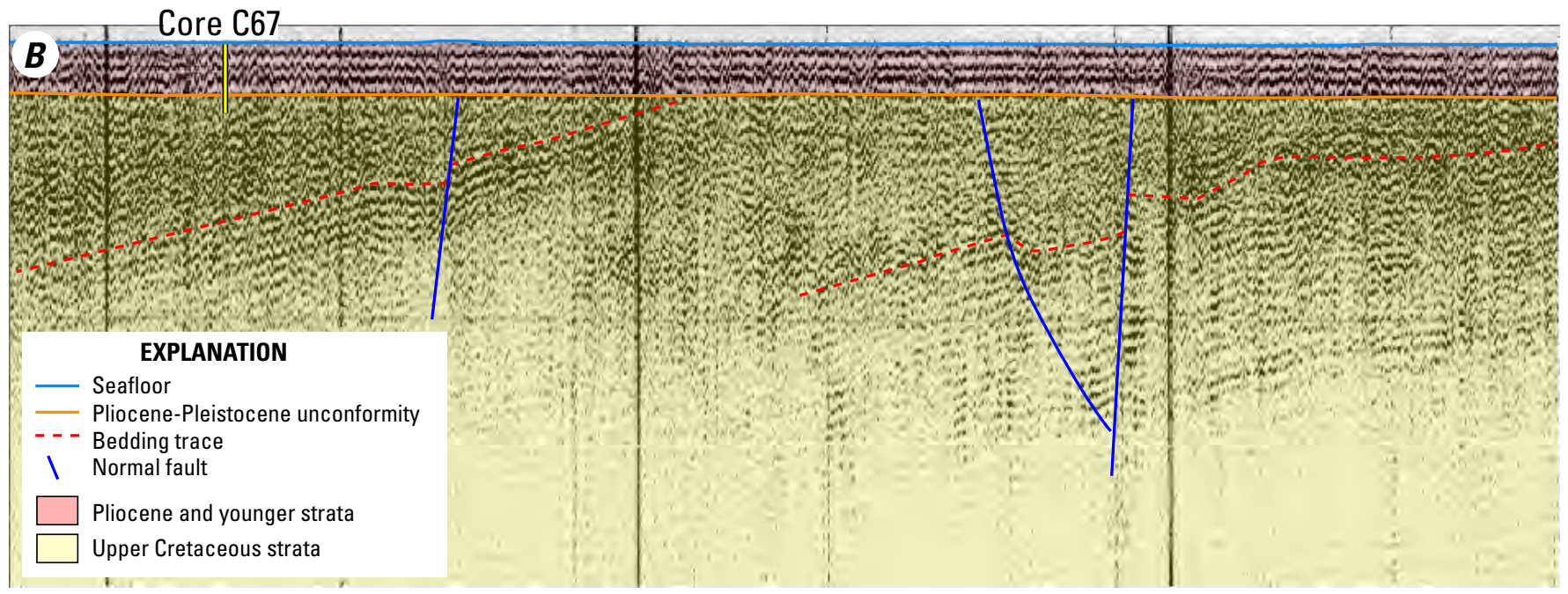

Figure 5. Seismic image across the location of U.S. Geological Survey vibracore C67, Chukchi Shelf, Alaska. Uninterpreted $(A)$ and interpreted $(B)$ uniboom seismic image illustrating Upper Cretaceous strata displaying apparent dip of less than $0.5^{\circ}$ west truncated by nearly horizontal Pliocene-Pleistocene unconformity. Each bedding trace may not be drawn on single stratum but indicates relative offset across normal faults. See figure 1 for core location. m, meters. 
clear quartz, zoned plagioclase, altered glassy rock fragments, large brown biotite in books and thin flakes, green hornblende, quartz with biotite, opaque heavy minerals, and clay minerals" and that the heavy mineral content ranges from 13.4 to 15.7 percent. Biotite from the lower and upper $30 \mathrm{~cm}$ of this unit yielded potassium-argon (K-Ar) ages of $95.2 \pm 1.2 \mathrm{Ma}(1$ standard deviation(?)) and $92.1 \pm 1.2 \mathrm{Ma}$ (late Cenomanian and early Turonian), respectively (Phillips and others, 1988).

\section{Vibracore D185AR-67 \\ Location: $70.27500^{\circ} \mathrm{N} ; 164.29500^{\circ} \mathrm{W}$ \\ Water depth: $41.5 \mathrm{~m}$ (136.2 ft)}

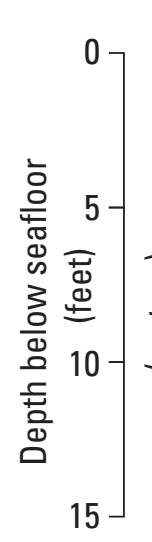

Figure 6. Graphic section and composite photograph of U.S. Geological Survey vibracore C67, Chukchi Shelf, Alaska.

Top of Upper Cretaceous strata indicated by yellow and black unconformity symbol. Numbered arrows correlate spots in graphic section to correlative spots in core photograph. Cores are stored in plexiglass half-tubes. See figure 1 for core location. Note that explanation applies to all related figures in this report. Scales on photograph are in centimeters. ft, feet; m, meters; ${ }^{40} \mathrm{Ar} /{ }^{39} \mathrm{Ar}$, argon-40/argon-39.

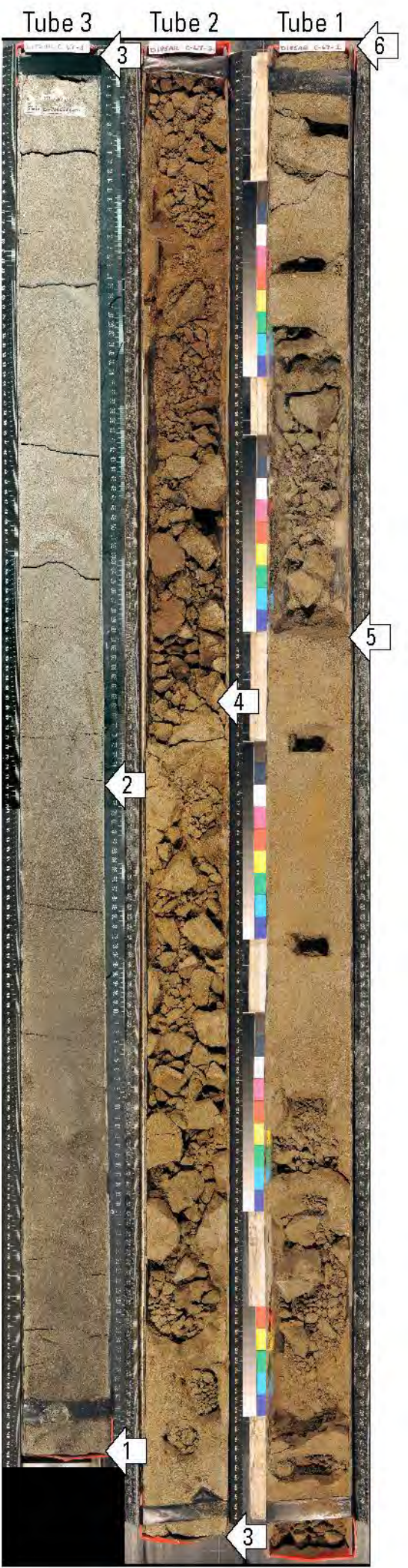


Phillips and others (1988) interpreted this unit as a beach, storm, or shelf deposit with biotite and heavy minerals concentrated by high energy winnowing. They concluded that the biotite and other volcanic detritus may have been eroded from a nearby source (implying that the unit is younger than indicated by the K-Ar dates) or may be a "primary unit of Cretaceous age," which we infer to mean that deposition was contemporaneous with volcanism. Considering the presence of tephra inferred to be air-fall volcanic ash in other nearby cores and the fining upward gradation from sandstone to sandy tephra, we interpret this unit to record the onset of air-fall volcanic ash deposition in a shoreface environment during the Late Cretaceous.

The top of the sandy tephra is in sharp contact with overlying $90-\mathrm{cm}$-thick, fine grained, nonfossiliferous sandstone (fig. 6, unit C67-b) that contains widely scattered pebbles. The weathered surface of the sandstone is tan to greenish gray, and fresher surfaces are reddish brown. The overlying $1.3-\mathrm{m}$-thick unit is very fine to fine grained sandstone that is distinctly carbonaceous and muddy in the lower $30 \mathrm{~cm}$ (fig. 6, unit C67-c). This unit ranges from greenish gray to reddish brown to dark gray, and is nonfossiliferous. Both sandstone units described here were considered Pleistocene in age by Elias and others (1992), and unpublished radiocarbon ages from two peat samples from the upper unit suggest an age near the Pleistocene-Holocene boundary (R. Phillips, 2002, written commun.). Based on the absence of marine fossils in the lower unit and the presence of peat in the upper unit, we infer a nonmarine depositional environment.

The upper $60 \mathrm{~cm}$ of core 67 is fine grained, tan sandstone containing common bivalve fragments and rare whole shells (fig. 6, unit C67-d). This unit was considered Holocene in age by Elias and others (1992) and was interpreted as marine by Phillips and Colgan (1987). We concur with those interpretations.

\section{Core 65}

Core 65 is located near the axis of the same westplunging anticline as cores 62 and 67. The anticline involves Cretaceous strata, which are truncated by a nearly horizontal PPU (fig. 7). Cretaceous strata display apparent dip of about $1^{\circ}$ west at the core location, and small displacement normal faults dip west nearby (fig. 7).

The lower $2.5 \mathrm{~m}$ of C65 is tephra (fig. 8, unit C65-a), which displays some vertical changes in character. The lower $130 \mathrm{~cm}$ is massive (structureless), pale greenish gray to white tephra that contains a few irregularly shaped patches stained greenish yellow to tan (fig. 8). Some of these are concentrated along fractures and their boundaries are diffuse. The overlying $80 \mathrm{~cm}$ is similar to the lower interval, except that the background color grades subtly upward to pale pinkish tan. More significantly, this interval includes discrete, ovoid, gray patches about $1 \mathrm{~cm}$ in diameter that are filled with material that contrasts in texture with surrounding tephra and that increase in abundance upward (fig. 8). A few of these gray patches contain pebbles. The upper $40 \mathrm{~cm}$ of tephra resembles the underlying interval but also displays discrete, gray to brown features that are round to ovoid and $1-5 \mathrm{~mm}$ in crosssectional dimension, and approximately linear and as much as $10 \mathrm{~cm}$ long in longitudinal section. These features are oriented within $30^{\circ}$ of vertical.

Three samples of the tephra (fig. 8, unit C65-a) were submitted for ${ }^{40} \mathrm{Ar} r{ }^{39} \mathrm{Ar}$ dating, and all yielded datable sanidine. Laser fusion ages of sanidines from samples S35, S36, and S37 are 89.24 $\pm 0.07 \mathrm{Ma}, 89.11 \pm 0.11 \mathrm{Ma}$, and $89.35 \pm 0.26 \mathrm{Ma}$ (reported errors are 1 standard deviation), respectively (fig. 9). These three dates are considered identical within the range of uncertainty and indicate ash deposition during the early Coniacian.

We interpret the tephra as air-fall volcanic ash deposited on land, owing to a lack of evidence supporting deposition in water and the lack of internal stratification. The uniformity of ${ }^{40} \mathrm{Ar}{ }^{39} \mathrm{Ar}$ dates likely indicates that the tephra represents a single ash-fall event. The ovoid gray patches that occur in the upper $120 \mathrm{~cm}$ of tephra are interpreted to be Thalassinoides or similar dwelling burrows. Unconsolidated to poorly consolidated tephra likely would be a favorable habitat for organisms that construct Thalassinoides and similar burrows, which are commonly developed in a firm-ground substrate. These trace fossils could have been formed at any time following deposition of the tephra, considering that the tephra likely was never buried far below the depositional surface. Considering that Thalassinoides burrows typically are formed by shrimp or similar crustaceans (Bromley, 1996), it is likely that the tephra was submerged by a brackish or marine flooding event before deposition of the overlying PliocenePleistocene nonmarine sandstone (see below). Alternatively, the Thalassinoides burrows could have been formed by crayfish, in which case the tephra may have been submerged by freshwater flooding. Pebbles observed in some of the traces likely were piped from an overlying depositional surface. The small diameter, elongate features in the upper $40 \mathrm{~cm}$ of tephra are interpreted as root traces, and these likely formed just before, or during, accumulation of the overlying nonmarine sand (see below). Thus, we interpret the tephra as a lower Coniacian volcanic ash fall deposited on land, and that the upper $120 \mathrm{~cm}$ was partly reworked by burrowing organisms and the upper $40 \mathrm{~cm}$ was partly reworked by rooting.

The top of the tephra is in sharp contact with a poorly sorted, pebbly, fine to medium grained, nonfossiliferous sandstone about $1.1 \mathrm{~m}$ thick (fig. 8, unit C65-b). The unit displays a range of colors, from tan and gray in the lower part to greenish gray and pale orange in the upper part. The lowermost $8 \mathrm{~cm}$ of this unit is muddy and displays indistinct, near-vertical features that resemble traces of inferred roots in the underlying tephra. Similar near-vertical features, some with concentrations of carbonaceous material, occur scattered throughout the unit. This entire unit was considered Pliocene(?) to Pleistocene in age by Elias and others (1992), and an unpublished radiocarbon age from a peat sample near 


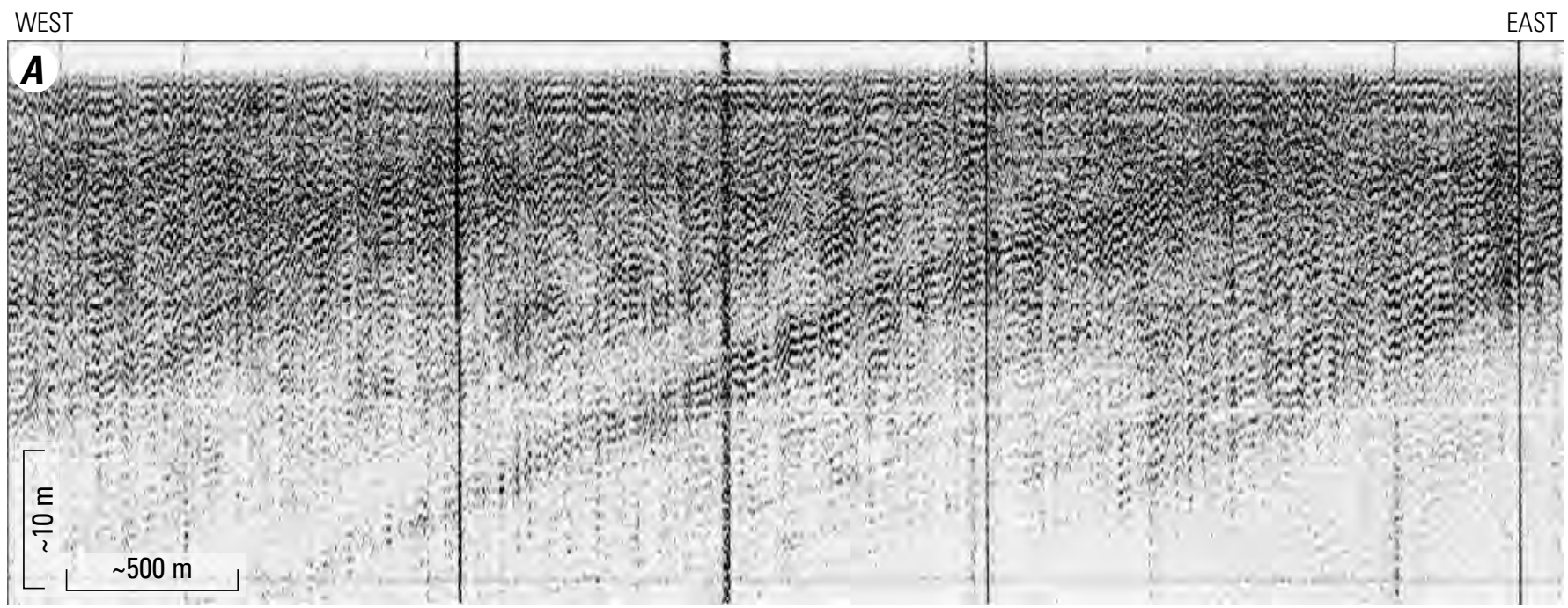

Vertical exaggeration $\sim 40 \mathrm{x}$

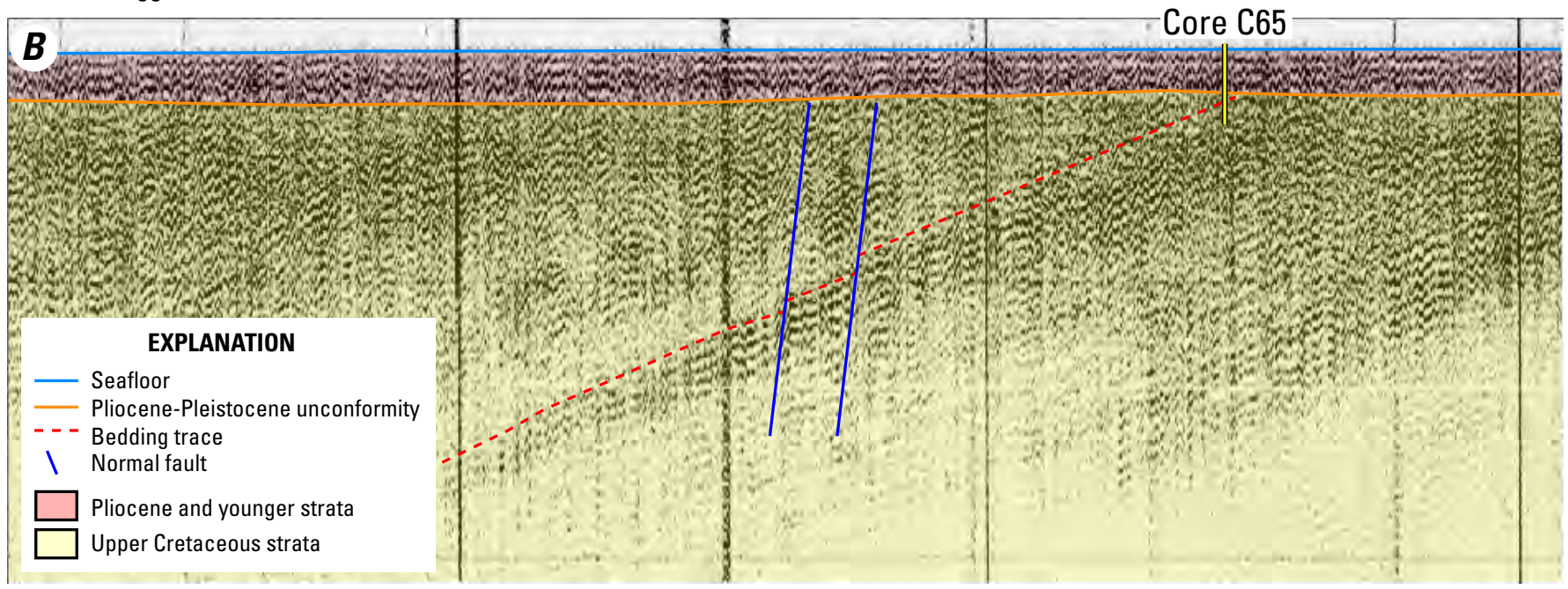

Figure 7. Seismic image across the location of U.S. Geological Survey vibracore C65, Chukchi Shelf, Alaska. Uninterpreted $(A)$ and interpreted $(B)$ uniboom seismic image illustrating Upper Cretaceous strata displaying apparent dip of about $1^{\circ}$ west truncated by a nearly horizontal Pliocene-Pleistocene unconformity. Bedding trace may not be drawn on single stratum but indicates relative offset across normal faults. See figure 1 for core location. m, meters. 
Vibracore D185AR-65

Location: $70.35670^{\circ} \mathrm{N} ; 164.75670^{\circ} \mathrm{W}$

Water depth: $45.2 \mathrm{~m}(148.3 \mathrm{ft})$

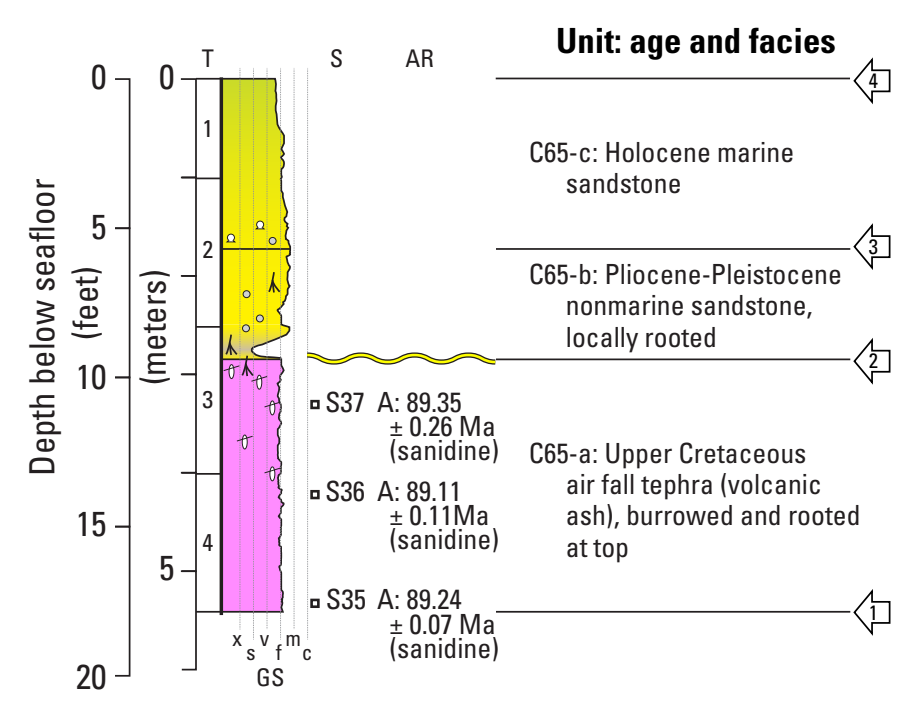

Figure 8. Graphic section and composite photograph of U.S. Geological Survey vibracore C65, Chukchi Shelf, Alaska. Top of Upper Cretaceous strata indicated by yellow and black unconformity symbol. Numbered arrows correlate spots in graphic section to correlative spots in core photograph. Cores are stored in plexiglass half-tubes. See figure 1 for core location. Note that explanation applies to all related figures in this report. Scales on photograph are in centimeters. ft, feet; $\mathrm{m}$, meters; ${ }^{40} \mathrm{Ar} /{ }^{39} \mathrm{Ar}$, argon-40/argon-39.

\section{EXPLANATION}

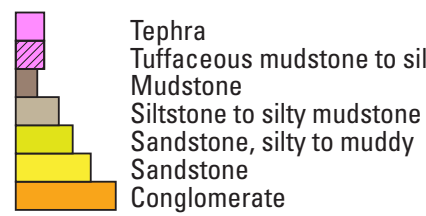

$\mathrm{T}$ - Core storage tube number (see core photos)

S - Sample spots

AR - Analytical results

- S25 - Sample spot and number

GS - Grain size; $x$, clay; s, silt; v, very fine sand; $f$, fine sand; $\mathrm{m}$, medium sand; $\mathrm{c}$, coarse sand

$\mathrm{A}:{ }^{40} \mathrm{Ar} /{ }^{39} \mathrm{Ar}$ age posted in million years

A: NR - No recovery of datable mineral

B: ND - No age determination

C: Apatite fission track cooling age posted in million years with \pm two standard errors

$\mathrm{D}$ : Detrital zircon $\mathrm{U} / \mathrm{Pb}$ age posted in million years with \pm one standard deviation

$\mathrm{T}$ : Total organic carbon (weight percent)
- Pebble
¿oos Pebble lag
- Trough cross laminae
- Concretions ¿ Trough cross bedding
- Flasers or clay laminae
- Convolute bedding
$\equiv$ Plane parallel laminae
A Root traces
* Burrows
b Trace fossils
\& Shells or shell fragments with \pm one standard deviation

B: Biostratigraphic age
Tube 4 Tube 3 Tube 2 Tube 1
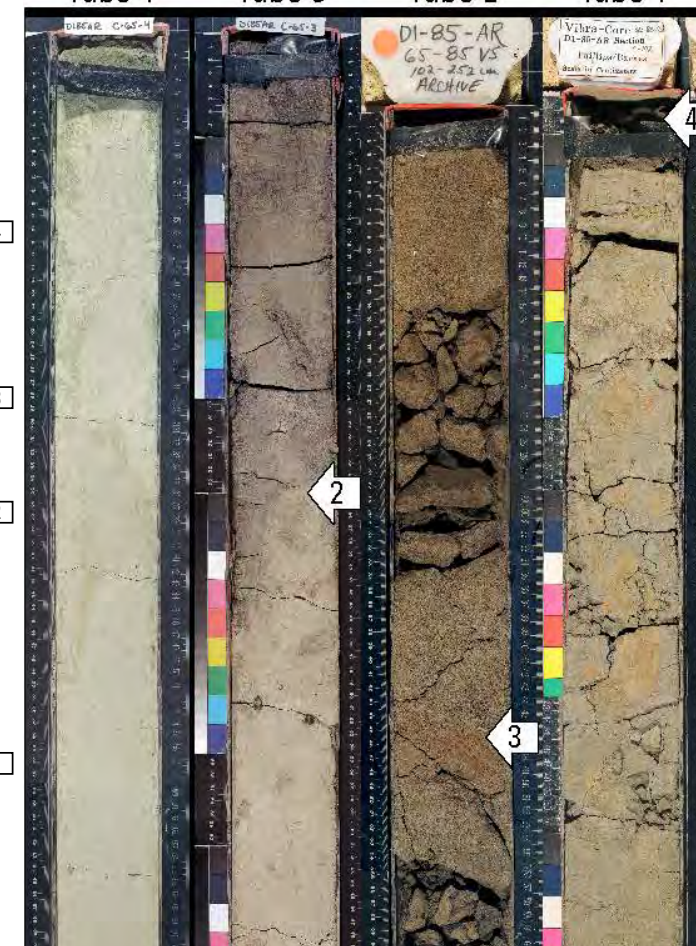

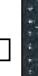
H

\section{.}




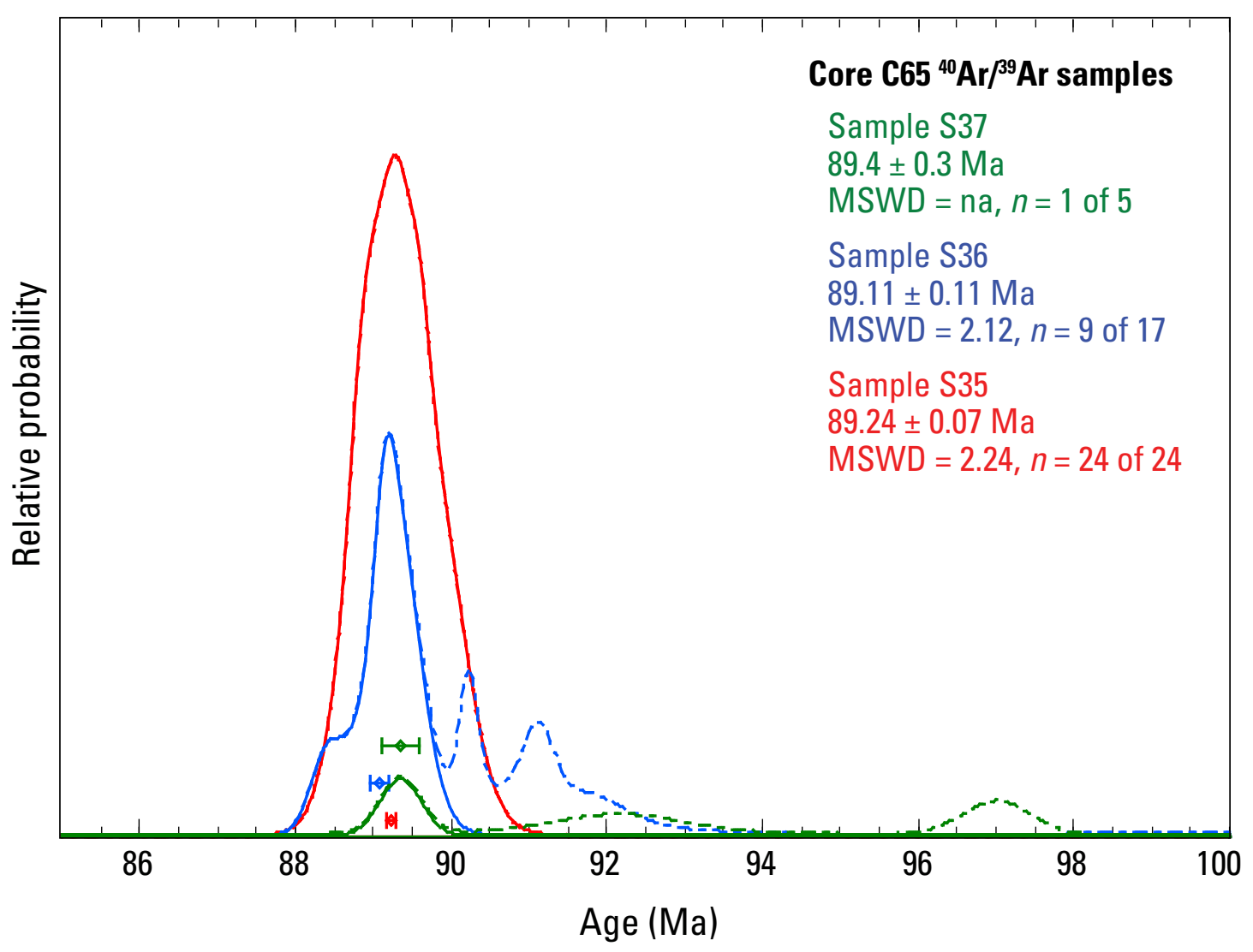

Figure 9. Graph showing age probability plots from argon-40/argon-39 $\left({ }^{40} \mathrm{Ar} /{ }^{39} \mathrm{Ar}\right)$ single-crystal laser-fusion analyses of sanidine grains from U.S. Geological Survey vibracore C65 (Chukchi Shelf, Alaska) tephra samples S35, S36, and S37 (fig. 8, unit C65-a). Solid lines are age probability plots for minimum age populations, inferred to represent age of volcanic ash fall; the three are equal within the range of uncertainty. These minimum age populations were used to calculate weighted mean ages posted on plot. Dashed lines are age probability plots for all data collected for each sample, and these include inferred detrital contaminant grains. Reported errors on cooling ages are 1 standard deviation. MSWD, mean square of the weighted deviates (unitless); Ma, mega-annum or millions of years ago; na, not applicable.

the top of the unit suggests a late Pleistocene age (R. Phillips, 2002, written commun.). Based on the absence of marine fossils, the presence of peat, and likely root traces scattered throughout, we infer a nonmarine depositional environment. It is unclear to us whether the inferred root traces in the upper part of the underlying tephra are related to incipient soil development during deposition of unit $\mathrm{C} 65-\mathrm{b}$ or if they may have formed during an earlier episode of soil development.

The upper $1.7 \mathrm{~m}$ of core is sandstone that fines upward from medium grained at the base to very fine to fine grained at the top (fig. 8, unit C65-c). The sandstone is generally similar in character to the underlying unit, except that it contains fewer and smaller pebbles and contains marine fossils (fig. 8). The color grades from gray-brown at the base to greenish gray and tan at the top. Orange iron staining increases toward the top. This unit was considered Holocene in age by Elias and others (1992), and an unpublished radiocarbon age from organic material near the base of the unit confirmed a Holocene age (R. Phillips, 2002, written commun.). This interval was interpreted as marine by Phillips and Colgan (1987), and we concur with that interpretation.

\section{Core 53}

Core 53 is located in an area of very low apparent dip (less than $0.5^{\circ}$ ) cut by numerous normal faults that display apparent dip both south and north; Cretaceous strata are truncated by a nearly horizontal PPU (fig. 10). The lower 1.1 $\mathrm{m}$ of $\mathrm{C} 53$ comprises $22 \mathrm{~cm}$ of very fine grained sandstone at the base overlain by nearly $90 \mathrm{~cm}$ of variably muddy siltstone (fig. 11, unit C53-a). The unit ranges from greenish gray to tan, except for some thin (less than $5 \mathrm{~mm}$ ), nearly white tuffaceous laminae in the upper half. A sample (S39) from the lower part of the mudstone $(5.7 \mathrm{~m}$ depth) was submitted for palynological analysis and yielded pollen, spores, and marine dinocysts that constrain both age and depositional environment. The palynological assemblage indicates an age of middle to late Coniacian, and deposition in a nearshore marine environment close to wet lowlands. The thermal alteration index (TAI) of the kerogen from this sample is 2-, which is equivalent to a vitrinite reflectance (VR) of 0.2 to 0.4 percent (Tissot and Welte, 1984). The sample also contains 
reworked pollen and dinocyst specimens of Early Jurassic age (probable Toarcian) and whose TAI is 4-, which is equivalent to about 1.6 percent VR.

Unit C53-b (fig. 11) is a sharp based, 70-cm-thick interval of sandstone, which includes $40 \mathrm{~cm}$ of fine grained sandstone at the base, $20 \mathrm{~cm}$ of very fine sandstone in the middle, and $10 \mathrm{~cm}$ of fine grained sandstone at the top. The basal sandstone is tan to greenish gray, and displays nearly vertical concentrations of black organic matter, as well as nearly horizontal flakes of black organic matter. The top of the basal sandstone is sharp and wavy, suggesting ripple preservation. The middle sandstone is medium gray and appears massive, except in the upper few $\mathrm{cm}$ where it is lighter colored and displays tuffaceous laminae. The upper sandstone is dark greenish gray to brown in color, and contains lighter colored blebs in the lower few $\mathrm{cm}$ that appear to be reworked from the underlying tuffaceous sandstone.

Detrital zircon $\mathrm{U} / \mathrm{Pb}(\mathrm{DZ})$ dating of a sample from the lower sandstone in unit C53-b (S38, fig. 11) produced an age spectrum with a distinct young detrital zircon $\mathrm{U} / \mathrm{Pb}$ age population (figs. 12A, B), likely derived from volcanism in Russian Chukotka. This young population, which can be used to constrain the maximum depositional age of the sandstone, yields an age of $95.24 \pm 0.69 \mathrm{Ma}$ (reported error is 2 standard deviations) (late Cenomanian). AFT analysis of 40 grains from this low thermal maturity sample (S38) yields a central cooling age of $103 \pm 8 \mathrm{Ma}$ (fig. 11; Craddock and Houseknecht, 2016). Although results from the AFT method are less precise than the DZ method, the DZ age estimate falls at the younger end of the uncertainty range of the AFT age estimate.

The combination of biostratigraphic, DZ, and AFT evidence clearly indicates a Late Cretaceous age for units C53-a and C53-b. Considering that the DZ and AFT dates (late Cenomanian) must be considered maximum ages, we infer that the mid to late Coniacian age provided by marine dinocysts best represents the age of these strata. The older DZ and AFT ages likely reflect recycling of volcanic zircon and apatite from older tephra, although we cannot rule out that the AFT age represents exhumational cooling of a provenance area (Craddock and Houseknecht, 2016). In addition, the weighted mean age for the young DZ population in sample S38 has a high mean square of the weighted deviates (MSWD, unitless) of 3.6; (fig. 12A,E), which may suggest that a mixture of multiple DZ age populations are being averaged. This lends support to the recycling hypothesis and suggests that the DZ maximum depositional age is an overestimate.

The lower $1.8 \mathrm{~m}$ succession (fig. 11, units $\mathrm{C} 53$-a and C53-b) does not display sedimentary structures that suggest a specific depositional setting, although the vertical concentrations of black, organic matter may be root traces and the organic flakes may be rip-ups of peat laminae. The presence of marine dinocysts in unit C53-a indicate deposition in a nearshore marine environment, for at least part of that unit. We therefore interpret this succession as shallow marine to nonmarine, and suggest a low-lying coastal setting.
The overlying $1.5 \mathrm{~m}$ of core comprises a lower tephra $60 \mathrm{~cm}$ thick, a middle tuffaceous mudstone $24 \mathrm{~cm}$ thick, and an upper tephra $66 \mathrm{~cm}$ thick (fig. 11, unit C53-c). This entire interval is distorted in a pattern consistent with drag-induced vibracoring damage. The lower tephra rests on the underlying sandstone with a sharp contact and is mainly white to pale green. The tephra varies from massive (structureless) to irregularly laminated. The tuffaceous mudstone is light gray to brown, and both the lower and upper few centimeters grade into adjacent tephra through interlamination of gray-brown mudstone and white tephra. The upper tephra is white to light gray in the lower $20 \mathrm{~cm}$ and grades upward to white and pale yellow. The upper few $\mathrm{cm}$ are brown capped by a white crust. Two samples of the tephra, one from the lower bed (S40) and one from the upper bed (S41), submitted for ${ }^{40} \mathrm{Ar} r{ }^{39} \mathrm{Ar}$ dating did not yield datable minerals (fig. 4). The entire lower 2.6 $\mathrm{m}$ of this core (units C53-a through C53-c) was considered Cretaceous in age by Elias and others (1992), and unpublished $\mathrm{K}-\mathrm{Ar}$ dates from the two tephras are early Cenomanian and early Turonian, in inverted stratigraphic order (R. Phillips, 2002, written commun.), broadly consistent with ages of inferred volcanic minerals in the underlying unit (C53-b) and in nearby cores.

This $1.5 \mathrm{~m}$ tephra-bearing succession (fig. 11, unit C53c) is more heterogeneous than tephra in cores C62 and C65. The lower tephra is massive and not muddy, and we interpret it as air-fall volcanic ash on land. The overlying tuffaceous mudstone clearly was deposited in water, suggesting flooding of the underlying volcanic ash, perhaps in a fluvial overbank or lake setting. The upward gradation from pure tephra below into tuffaceous mudstone suggests that flooding occurred while volcanic ash continued to fall. The upward gradation from tuffaceous mudstone into the upper tephra suggests cessation of flooding, or that the relative rate of volcanic ash fall increased and filled available accommodation, and that the upper tephra mainly represents volcanic air fall on land. The irregular top of the upper tephra may be an unconformity hard ground, as suggested by the white crust and contorted geometry at the top of the tephra (fig. 11).

The tephra-bearing interval is overlain by sharp-based, fining-upward (fine to very fine grained), pebbly sandstone about $50 \mathrm{~cm}$ thick (fig. 11, unit C53-d). Flakes of black organic matter are present in the upper half of the sandstone, and the upper few centimeters contain finely disseminated organic matter (fig. 11). The sandstone grades upward from gray, to greenish gray, to dark gray. This unit was interpreted tentatively as Pliocene(?) in age by Elias and others (1992), and we have no evidence to the contrary. We interpret this sandstone to be nonmarine in origin given the erosive base and the possible presence of root traces and likely a thin fluvial deposit.

The top $2.1 \mathrm{~m}$ of $\mathrm{C} 53$ comprises about $80 \mathrm{~cm}$ of mainly very fine grained sandstone overlain by $1.3 \mathrm{~m}$ of siltstone to very fine grained sandstone (fig. 11, unit C53-e). Clasts as much as $3 \mathrm{~cm}$ in diameter and marine shell fragments are concentrated near the base, and both whole shells and shell 


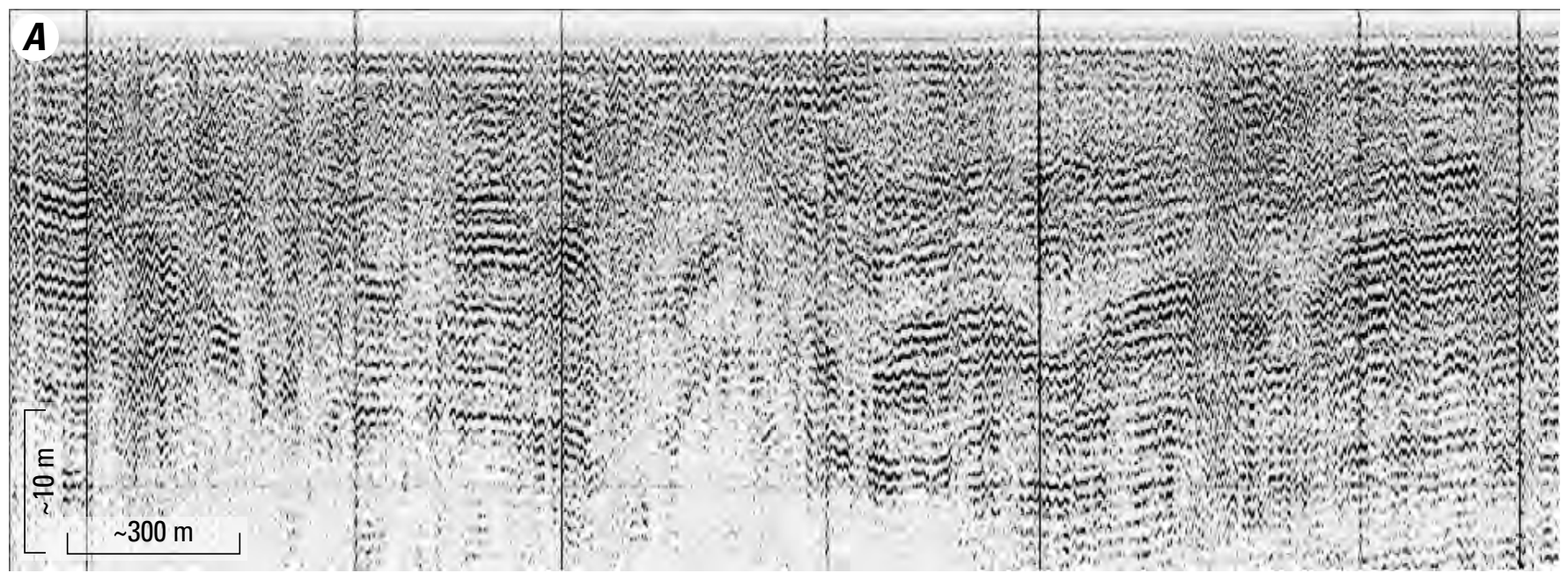

Vertical exaggeration $\sim 20 x$

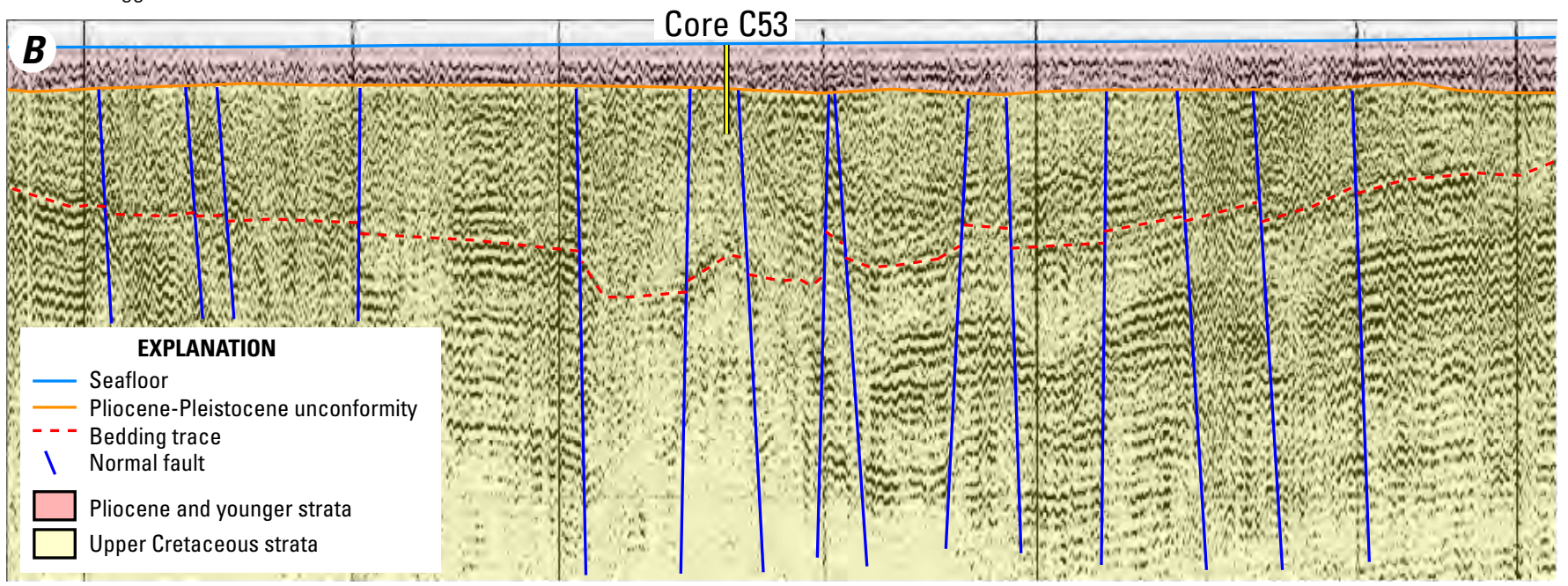

Figure 10. Seismic image across the location of U.S. Geological Survey vibracore C53, Chukchi Shelf, Alaska. Uninterpreted $(A)$ and interpreted $(B)$ uniboom seismic image illustrating Upper Cretaceous strata that display very low angle apparent dip (less than $0.5^{\circ}$ ) and numerous, closely spaced normal faults of small displacement truncated by nearly horizontal Pliocene-Pleistocene unconformity. Bedding trace may not be drawn on single stratum but indicates relative offset across normal faults. See figure 1 for core location. $m$, meters. 


\section{Vibracore D185AR-53}

Location: $70.54833^{\circ} \mathrm{N} ; 165.91333^{\circ} \mathrm{W}$

Water depth: $47.0 \mathrm{~m}$ (154.2 ft)

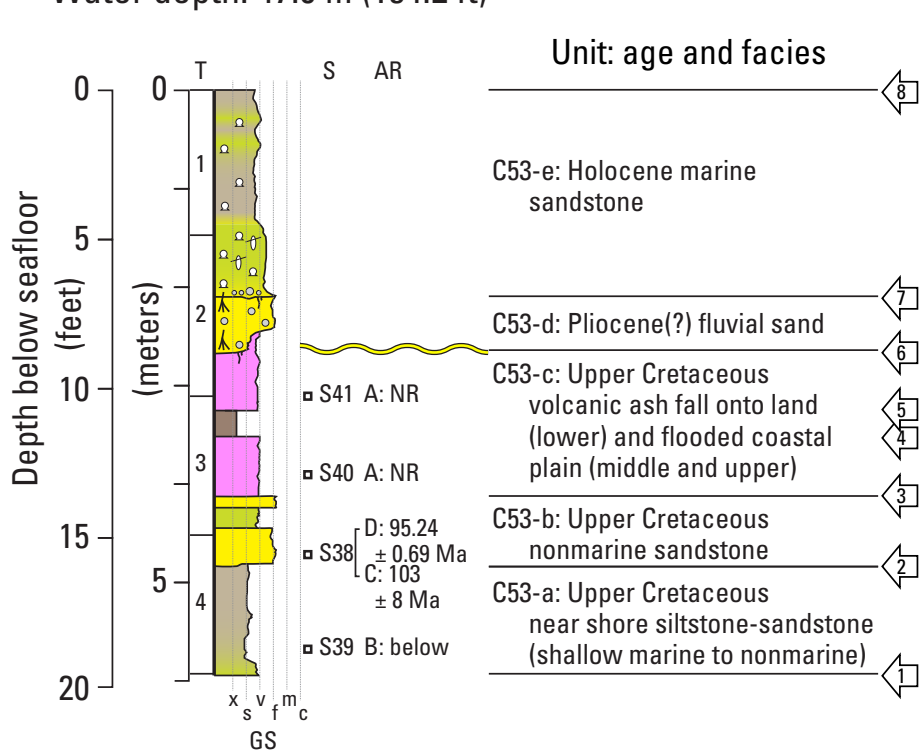

Sample S39 biostratigraphy: palynomorphs are long-ranging and not age-diagnostic; marine dinocysts indicate middle to late Coniacian age and marine deposition close to wet lowlands; in-situ kerogen has TAI of 2- (VR $0.2-0.4 \%)$; contains reworked pollen and dinocysts of Early Jurassic age; reworked kerogen has TAl of 4- (VR 1.6\%)

Figure 11. Graphic section and composite photograph of U.S. Geological Survey vibracore C53, Chukchi Shelf, Alaska. Top of Upper Cretaceous strata indicated by yellow and black unconformity symbol. Numbered arrows correlate spots in graphic section to correlative spots in core photograph. Cores are stored in plexiglass half-tubes. See figure 1 for core location. Note that explanation applies to all related figures in this report. Scales on photograph are in centimeters. ft, feet; $\mathrm{m}$, meters; ${ }^{40} \mathrm{Ar} /{ }^{39} \mathrm{Ar}$, argon-40/argon-39.

\section{EXPLANATION}

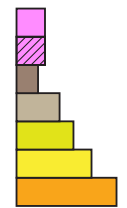

Tephra

Tuffaceous mudstone to silty mudstone Mudstone

Siltstone to silty mudstone

Sandstone, silty to muddy

Sandstone

Conglomerate

$\mathrm{T}$ - Core storage tube number (see core photos)

$S$ - Sample spots

AR - Analytical results

- S25 - Sample spot and number

GS - Grain size; $x$, clay; s, silt; $v$, very fine sand; $f$, fine sand; $\mathrm{m}$, medium sand; $\mathrm{c}$, coarse sand

$\mathrm{A}:{ }^{40} \mathrm{Ar} /{ }^{39} \mathrm{Ar}$ age posted in million years with \pm one standard deviation

A: NR - No recovery of datable mineral

B: Biostratigraphic age

B: ND - No age determination

C: Apatite fission track cooling age posted in million years with \pm two standard errors

$\mathrm{D}$ : Detrital zircon $\mathrm{U} / \mathrm{Pb}$ age posted in million years with \pm one standard deviation

T: Total organic carbon (weight percent)
- Pebble
.000 Pebble lag
.. Concretions
Trough cross laminae
- Flasers or clay laminae
to Convolute bedding
$\equiv$ Plane parallel laminae

Tube 4 Tube 3 Tube 2 Tube 1
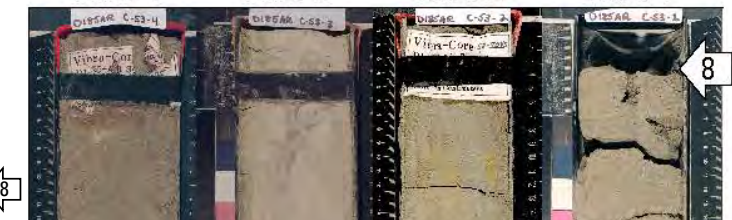

.

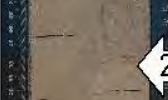

2

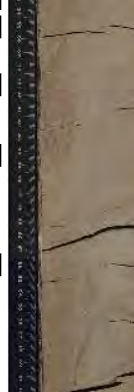

\section{.}

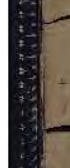



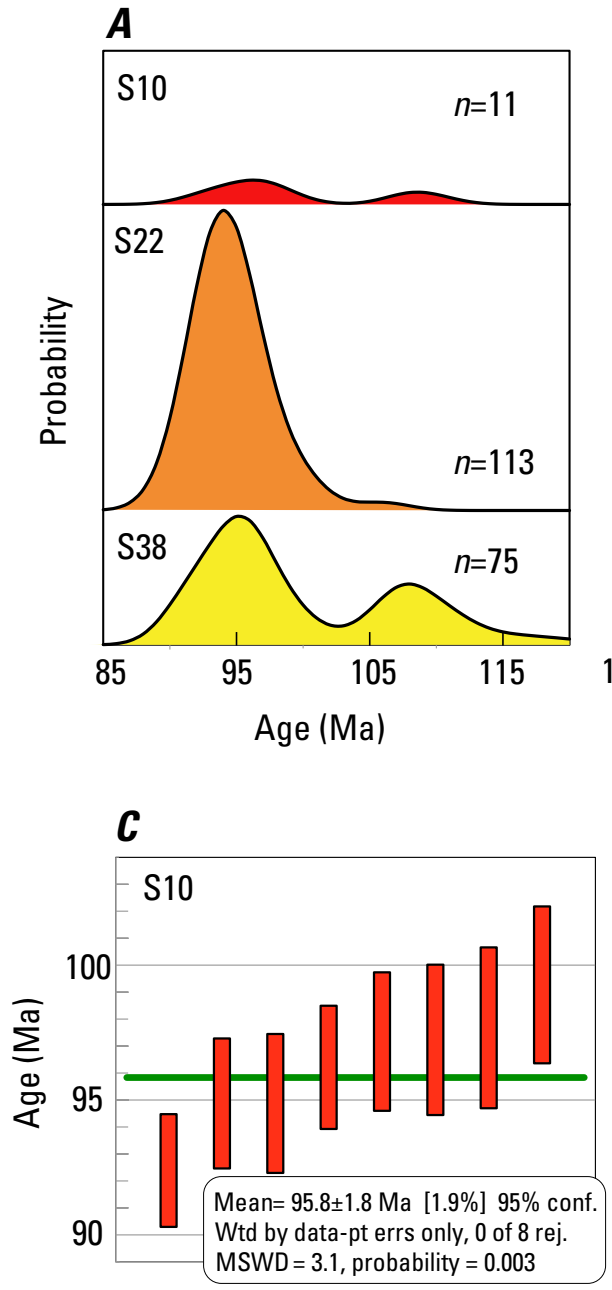

B

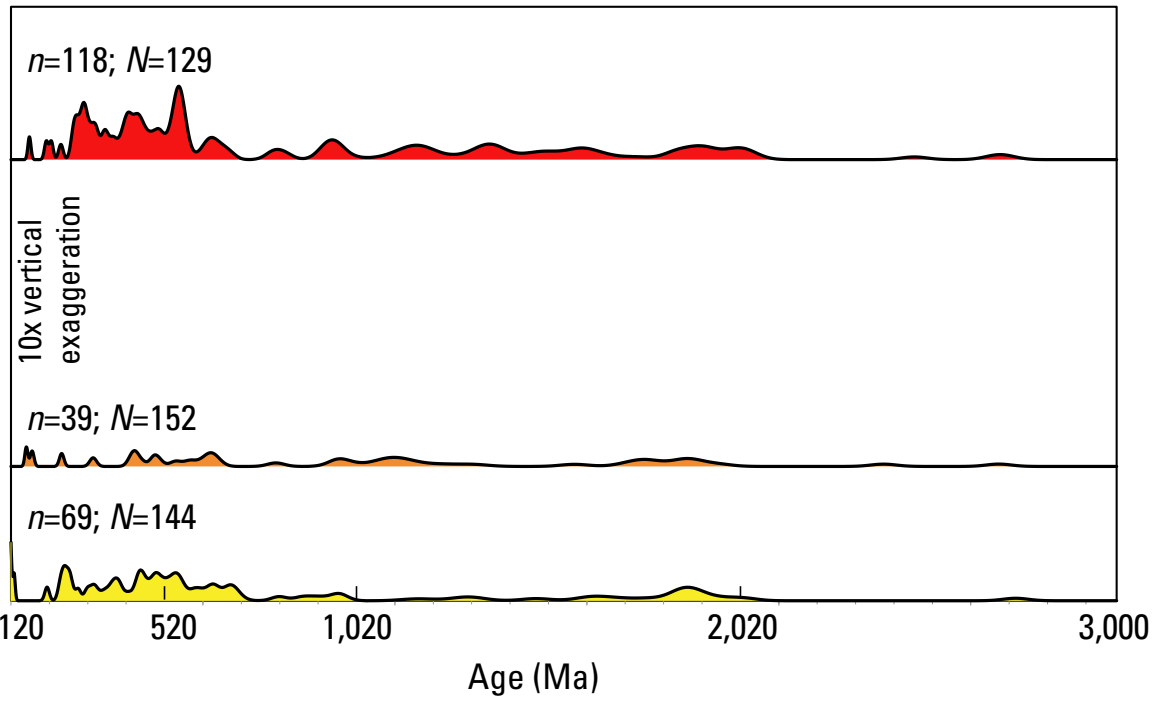

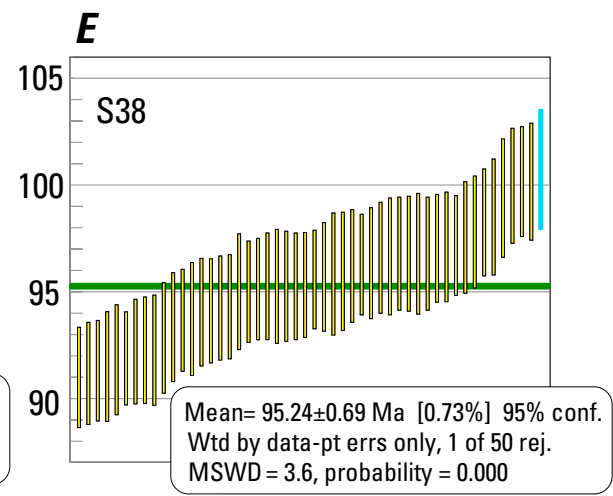

Figure 12. Detrital zircon uranium/lead (U/Pb) age data for three sandstone samples from shallow cores on the Chukchi Shelf, Alaska, including samples S10 and S22 from U.S. Geological Survey rotary core C3 (fig. 15) and sample S38 from vibracore 53 (fig. 11). A, Age spectrum (probability density function) for each sample for grain population between 85 and $120 \mathrm{Ma}$ (mega-annum or millions of years ago); $B$, Age spectrum (probability density function) for each sample for grain population between 120 and 3,000 Ma. Probability scale is exaggerated 10 times in $B$ compared to $A$. In both plots, $n=$ number of grains in population of specific age range; $N=$ total number of grains dated in each sample. $C$, Plot of youngest zircon age population for sample $S 10$. Green bar is mean; standard deviation is 1.89 percent of population mean at 95-percent confidence. D, Plot of youngest zircon age population for sample S22. Green bar is mean; standard deviation is 0.36 percent of population mean at 95 percent confidence. $E$, Plot of youngest zircon age population for sample S38. Green bar is mean; standard deviation is 0.69 percent of population mean at 95 percent confidence. In $C$, $D$, and $E$, each bar represents the age of one zircon grain; bar height is 2 standard deviations; red, orange, and yellow bars (color matches age spectra in $A$ and $B$ ) are zircon ages used to calculate weighted mean ages posted on plots; blue bars are zircon ages rejected on basis of standard error values; green line is weighted mean; MSWD, mean square of the weighted deviates (unitless). Population statistics are weighted by data-point errors (Wtd by data-pt errs) only. Probability refers to the $p$-value of a chi-squared test. \% conf., percent confidence; rej., rejected. 
fragments are present throughout this succession. The basal sandstone is bioturbated. No sedimentary structures are evident. The unit is greenish gray throughout, with irregular patches of white to yellow to orange stain in the lower $75 \mathrm{~cm}$. This succession was interpreted as Holocene in age by Elias and others (1992), which we accept. We interpret unit C53-e as marine in origin, based mainly on the abundance of marine fossils.

\section{Rotary Cores}

Two rotary cores containing inferred pre-Cenozoic strata are included in this study (fig. 1; C3 and C7). Although the rotary cores are well preserved, they display significant damage induced by the coring process. The damage includes disking, fracturing, fragmentation, disaggregation, and impregnation by drilling mud (fig. 13). Disking is pervasive and is expressed as 1- to 4-cm-thick disks of rock with convex-upward boundaries; disks are separated by 1 - to 5-mm-thick layers of drilling mud. The convex-upward surfaces of many disks display circular striations, indicating rotation during coring. In addition, core recovery was limited in some intervals, particularly in the younger part of the section containing weakly consolidated or unconsolidated strata. Despite the core damage, many sedimentary features remain intact or can be inferred. General descriptions of the rotary cores follow. Geochronology, biostratigraphy, organic petrology, and thermal maturity results are included with the core descriptions.

\section{Core 3}

Rotary core 3 , drilled in $53.9 \mathrm{~m}$ of water, reached a total depth of approximately $53 \mathrm{~m}$ below the seafloor (Winters and Lee, 1985). The geologic context of the core is constrained by shallow, high-resolution seismic-reflection data collected by the USGS in 1984 (fig. 14). The core is located on the margin of an incision on the mid-Brookian unconformity (MBU; fig. 2 ); the maximum depth of the incision is about $55 \mathrm{~m}$ below the seafloor. The unconformity at the base of Pliocene-Pleistocene strata also is shown (fig. 14). Strata below the MBU display apparent dip to the north of $1-2^{\circ}$, whereas strata above the MBU are approximately horizontal, although the incision fill is multistoried, with several vertically stacked channel-fill sequences (fig. 14).

The bottom $20.7 \mathrm{~m}$ of C3 (32.3 to $53.0 \mathrm{~m}$ depth) comprises variably tuffaceous mudstone, siltstone, and sandstone with interbeds of tephra (fig. 15). The interval between 45.8 and $53.0 \mathrm{~m}$ depth (fig. 15, unit $\mathrm{C} 3$-a) comprises multiple fining upward sequences, most of which are between 1.0 and $1.5 \mathrm{~m}$ thick. Each sequence typically has a sharp base overlain by thin $(10$ to $40 \mathrm{~cm})$, very fine grained sandstone that fines upward to siltstone and mudstone. Sandstone and siltstone are mainly light gray to pale greenish gray, and mudstone is mainly medium gray. These background colors are modified with greenish to yellowish tints where the rocks are tuffaceous. Vertical features that appear to be 5 to $8 \mathrm{~mm}$ wide, sand-filled burrows, are present locally in sandstone beds. Thinner (1 to $3 \mathrm{~mm}$ ), dark gray vertical features that resemble root traces are present locally in siltstone and mudstone. However, we could not confirm whether any of these vertical features are in situ biogenic structures or coring damage.

Four mudstone samples (S1, S3, S8 and S11, fig. 15) from unit $\mathrm{C} 3$-a were submitted for palynological analysis. Palynomorph recovery was low in three of the samples, and all four samples contained long-ranging spores that are not age-diagnostic. Two samples (S3 and S11) contained solitary specimens of a marine dinocyst indicative of middle to late Coniacian age. The low abundance suggests that either the dinocysts were transported into a nonmarine environment by storms, or were recycled from older sediments. Consequently, a low confidence level is associated with the inferred middle to late Coniacian age, and the palynomorph assemblage suggests deposition in a coastal plain to nearshore shallow-marine environment. Kerogen concentrated from all four samples has a TAI of 1 , equivalent to about 0.1 percent VR. Reworked palynomorphs are common in samples S8 and S11, and they indicate a probable Early Jurassic age and are characterized by a TAI of 4- (about 1.6 percent VR). Sample S11 also was submitted for micropaleontological analysis, but did not contain microfauna.

Organic geochemical analyses of two samples (S1 and S11) from unit C3-a are summarized in table 1. Total organic carbon (TOC) content is low ( 0.60 and 0.44 percent, respectively), hydrogen index (HI) is low (17 and 2, respectively), and oxygen index (OI) is high (337 and 212, respectively). Vitrinite reflectance analysis did not yield results as insufficient kerogen was identified as $i n$-situ vitrinite to collect reflectance data. Petrographic observations include the presence of very low reflectance bitumen in both samples. All these results are consistent with the low thermal maturity inferred from the palynological analysis, and indicate that these samples are not of petroleum source-rock quality.

DZ dating of a sample from the lowest sandstone in unit C3-a (S10, fig. 15) produced an age spectrum with a distinct young detrital zircon $\mathrm{U} / \mathrm{Pb}$ age population, likely derived from volcanism in Russian Chukotka. This young population, which can be used to estimate the maximum depositional age of the sandstone, yields an age of $95.8 \pm 1.8 \mathrm{Ma}$ (late Cenomanian), though with a high MSWD of 3.1. A sample of tuffaceous mudstone (S4) from near the middle of unit C3-a was submitted for ${ }^{40} \mathrm{Ar} /{ }^{39} \mathrm{Ar}$ dating and did not yield datable minerals (fig. 15).

Biostratigraphic evidence suggests a low confidence, mid to late Coniacian age, whereas DZ data indicate a maximum possible age of late Cenomanian. These constraints clearly indicate an early Late Cretaceous age, and a more detailed interpretation is difficult. We therefore interpret unit $\mathrm{C} 3$-a as Upper Cretaceous nonmarine to nearshore shallow-marine deposits. 


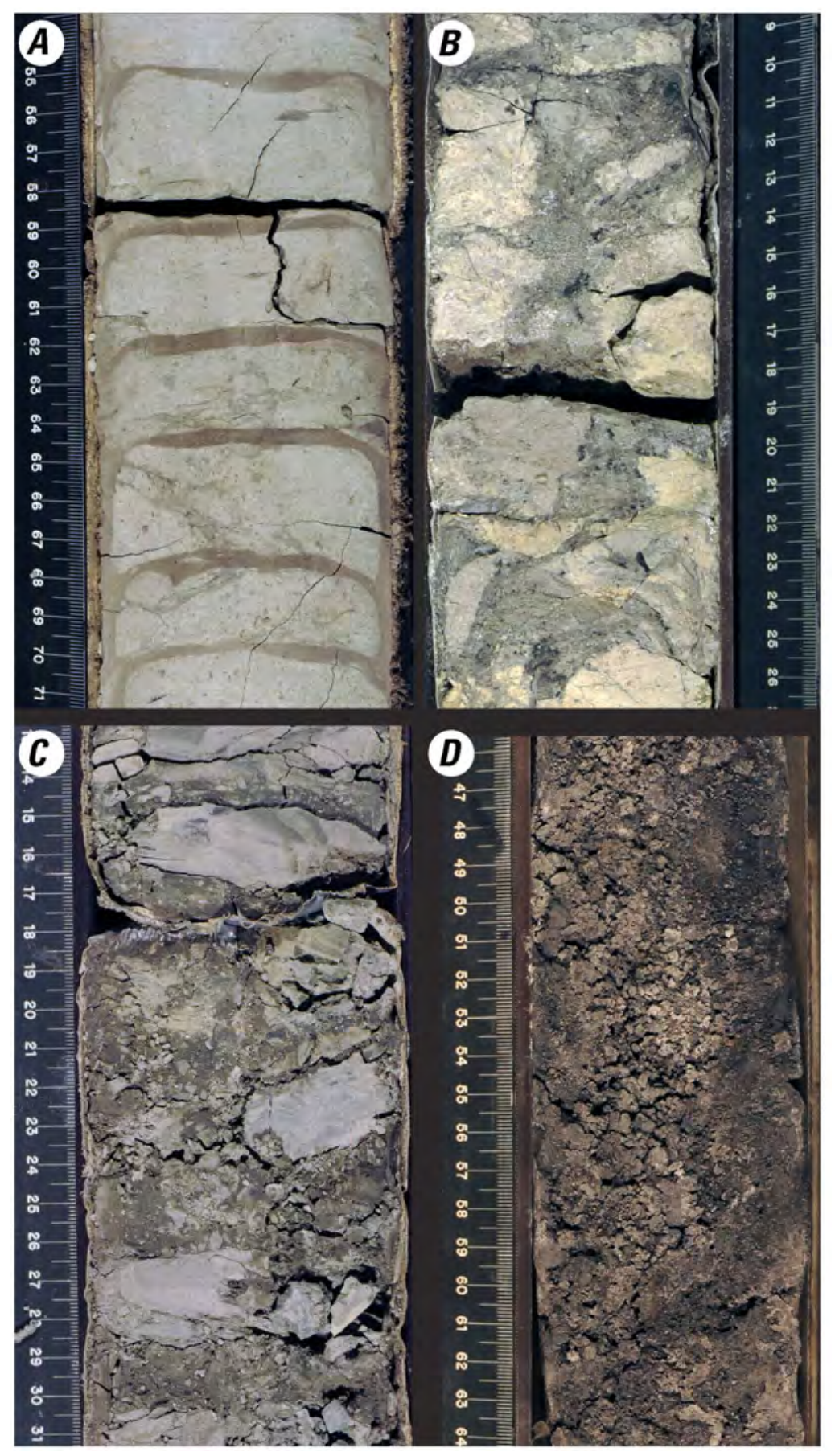

Figure 13. Composite photograph of U.S.

Geological Survey cores from the Chukchi Shelf, Alaska, showing examples of damage induced by rotary coring. $A$, Disking and mud impregnation; $B$, fracturing and mud impregnation; $C$, fragmentation and mud impregnation; $D$, disaggregation and mud impregnation. Scales on photograph are in centimeters. 


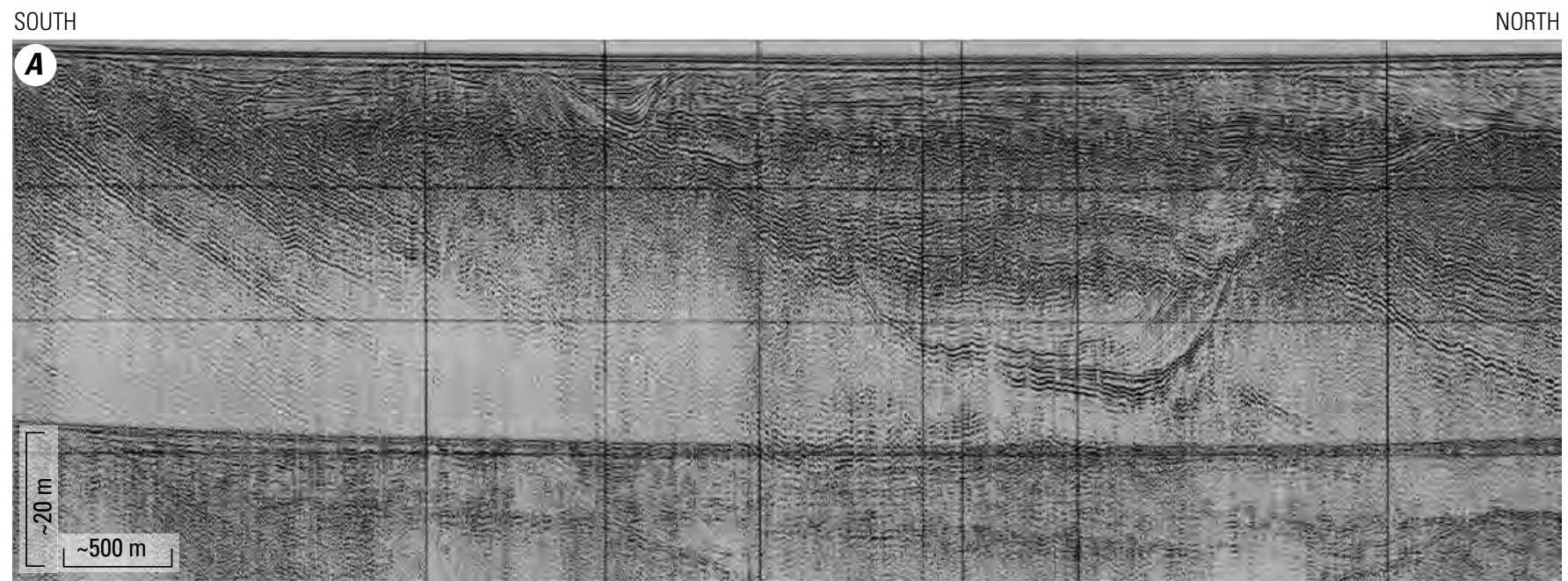

Vertical exaggeration $\sim 30 \mathrm{x}$

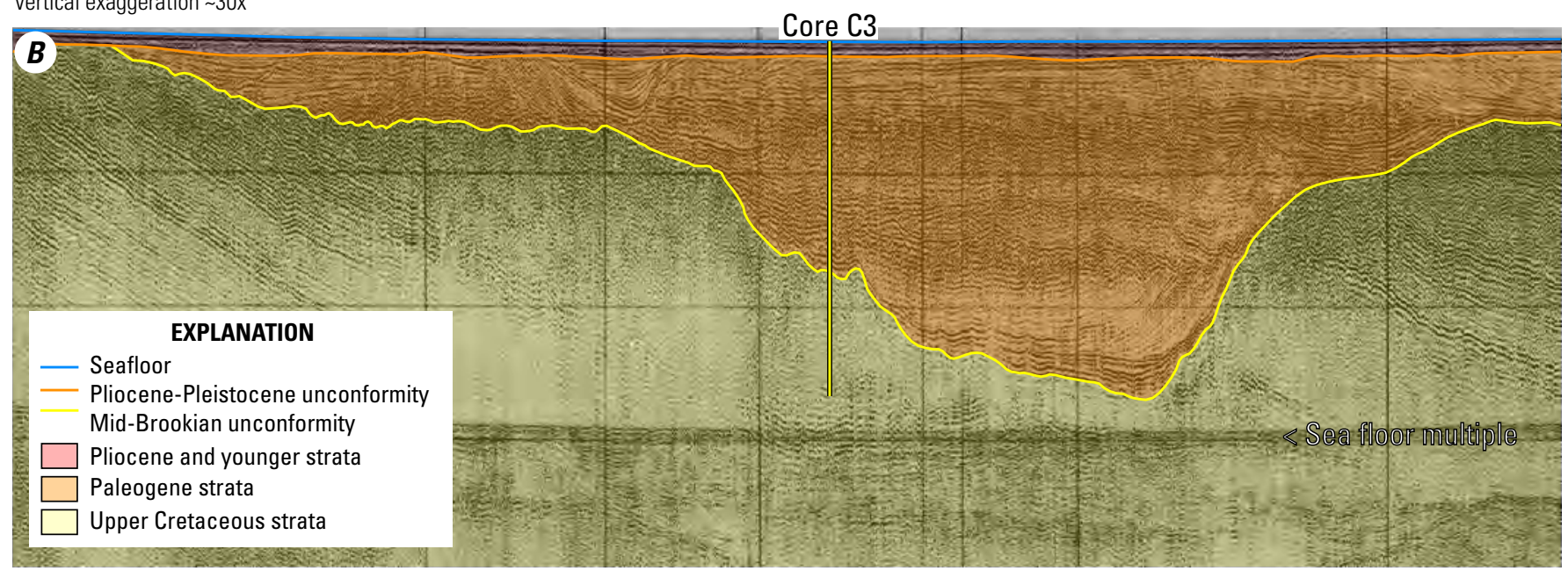

Figure 14. Seismic image across the location of U.S. Geological Survey rotary core C3, Chukchi Shelf, Alaska. Uninterpreted $(A)$ and interpreted $(B)$ uniboom seismic illustrating Upper Cretaceous strata displaying apparent dip of $1-2^{\circ}$ north truncated by the midBrookian unconformity, which displays deep incision. Pliocene-Pleistocene unconformity (PPU) also is shown. Note angularity between Cretaceous and Paleogene strata, visible despite multiple incisions and channel-fill geometries in Paleogene strata. See figure 1 for core location. m, meters.

Figure 15. Graphic section of U.S. Geological Survey rotary core C3, Chukchi Shelf, Alaska. Top of Upper Cretaceous strata uncertain as explained in text; possible top indicated by dotted yellow and black unconformity symbols. Numbered arrows correlate spots in graphic section to correlative spots in core photographs in figure 16. See figure 11 for explanation. 


\section{Rotary core K183CS-3}

Location: $70.66690^{\circ} \mathrm{N} ; 167.32660^{\circ} \mathrm{W}$

Water depth: $53.9 \mathrm{~m}(176.8 \mathrm{ft})$

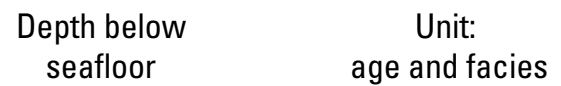

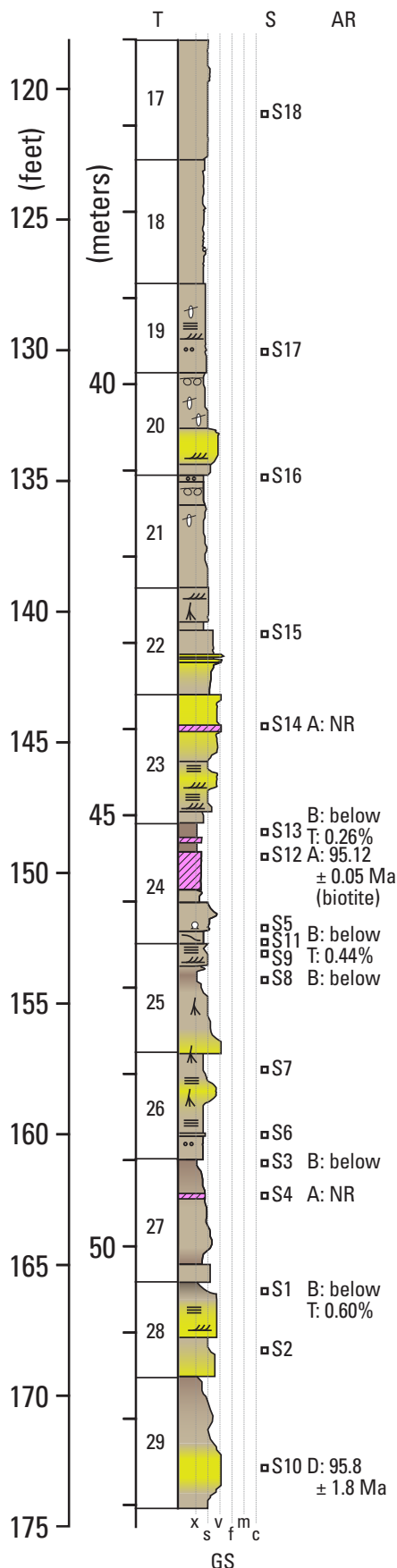

Depth below
seafloor

Unit:
age and facies

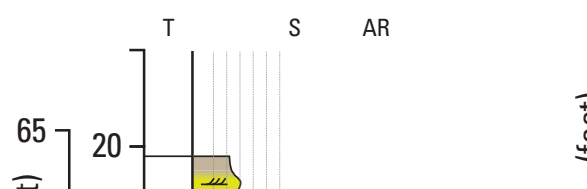

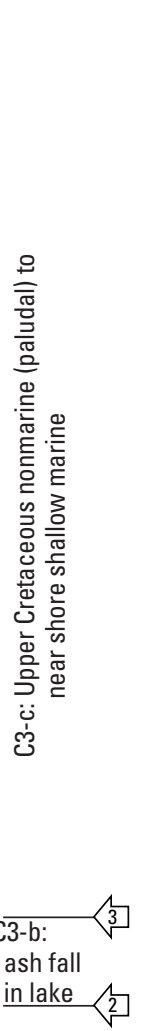
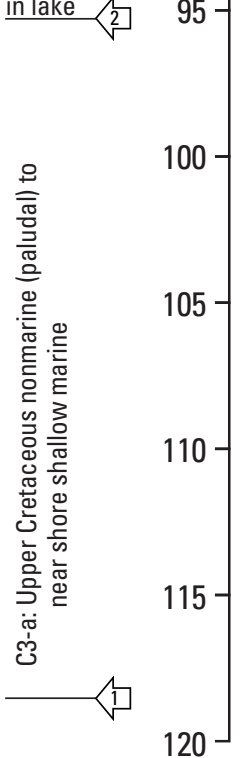

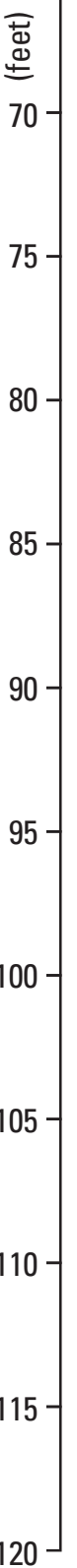
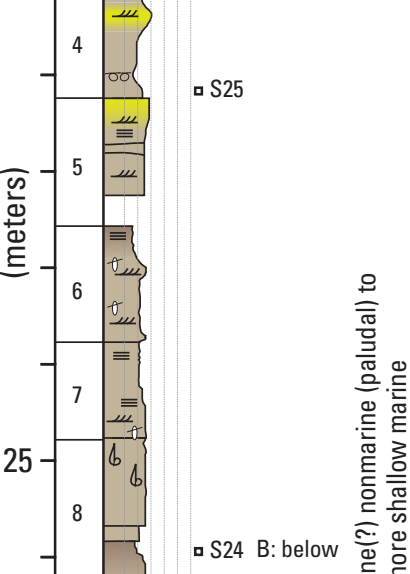

.

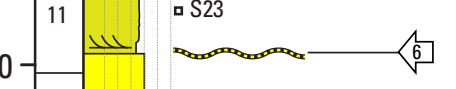

$35-$

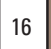

ปัँ

40

- S22 D: 94.71 政

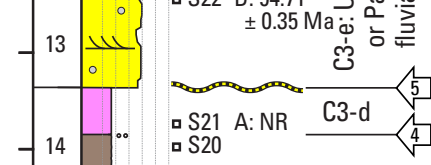

14

S19 B: below

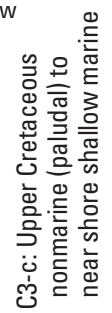

GS

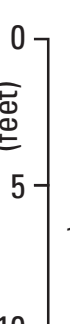
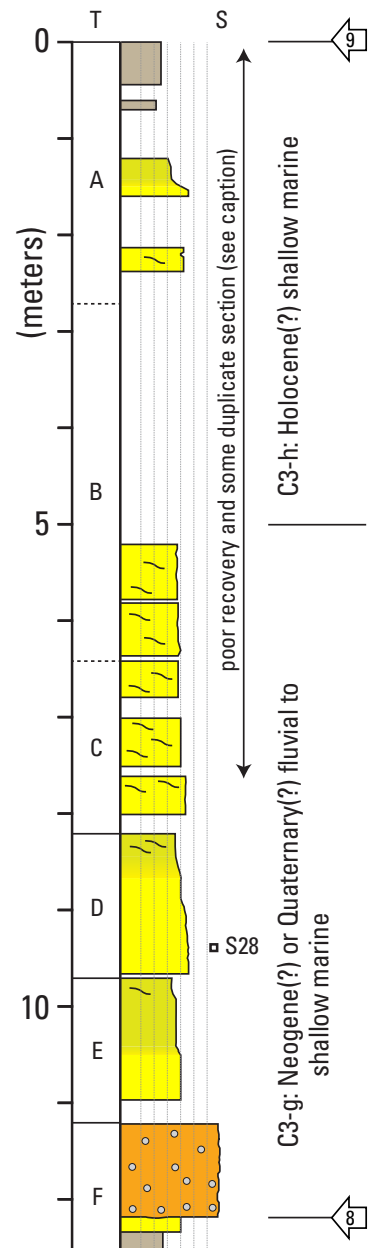

Depth below Unit:
seafloor

Samples S1, S3, S8 and S11 biostratigraphy: palynomorphs are long-ranging and not age-diagnostic; S3 and $\mathrm{S} 11$ contain marine dinocysts of middle to late Coniacian age (low confidence because dinocysts are solitary specimens); kerogen TAI is 1 (VR $\sim .1 \%$ ); S8 and S11 contain reworked Early Jurassic palynomorphs with TAI of 4- (VR 1.6\%). Samples S13 and S19 biostratigraphy: palynomorphs are long-ranging and not agediagnostic, but indicate deposition in or near lowland swamps; kerogen TAl is 2- (VR $~ 0.2-0.4 \%$ ); contains reworked Early Jurassic pollen with TAI of 4- (VR 1.6\%). Sample S24 biostratigraphy: palynomorphs are longranging and not age-diagnostic; presence of cool climate pollen suggests Oligocene age, but this is tentative; kerogen TAI is 1 (VR $~ 0.1 \%$ ); contains reworked Campanian - Maastrichtian dinocysts. 


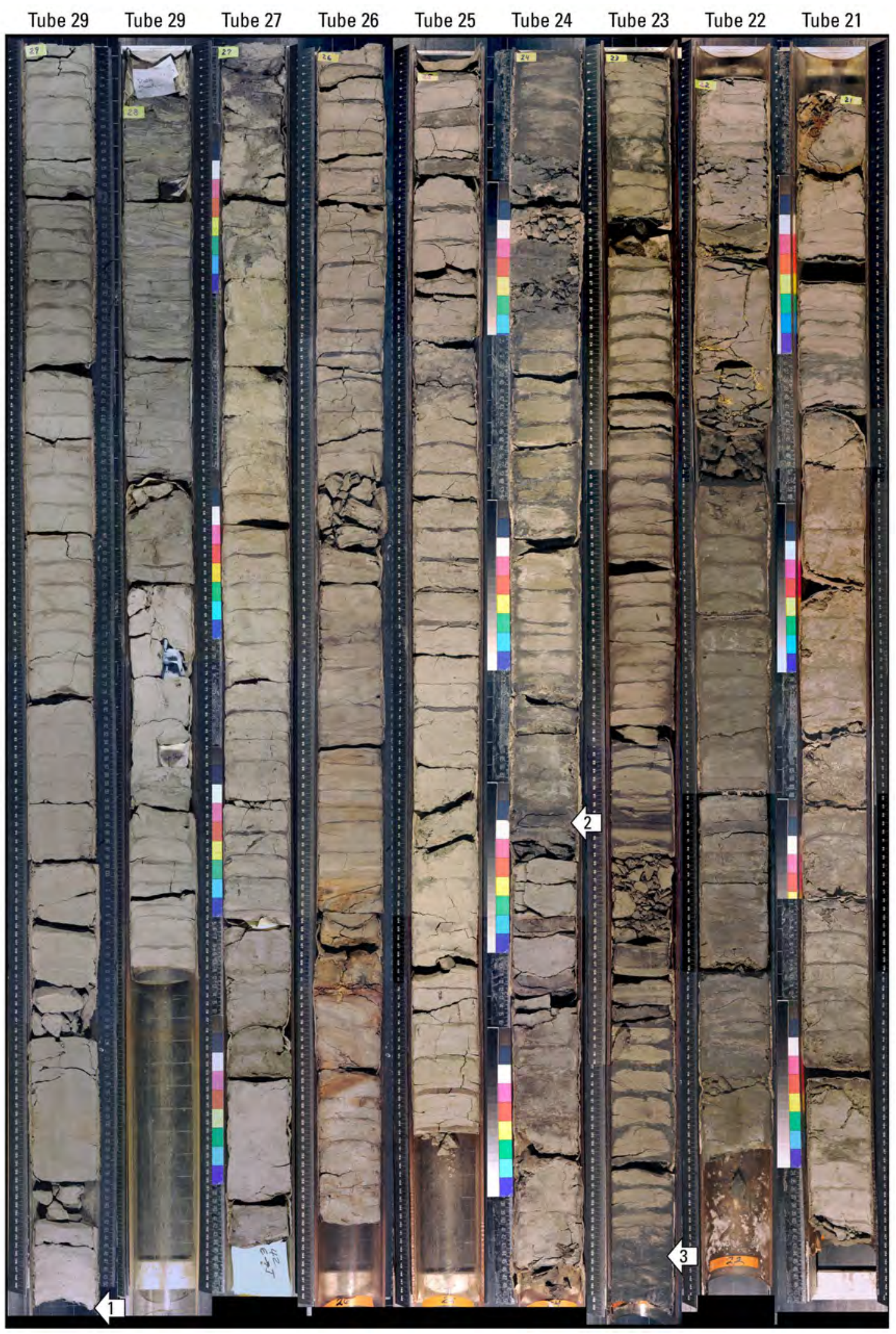

Figure 16. Composite photographs of U.S. Geological Survey rotary core C3, Chukchi Shelf, Alaska. $A$, Composite photograph of rotary core C3, tubes 29-21; numbered arrows correlate to graphic section in figure 15. $B$, Composite photography of rotary core C3, tubes 20-12; numbered arrows correlate to graphic section in figure 15. C. Composite photography of rotary core $C 3$, tubes 11-3; numbered arrows correlate to graphic section in figure 15 . $D$, Composite photography of rotary core $C 3$, tubes $2-A$; numbered arrows correlate to graphic section in figure 15. See figure 1 for core location. Scales on photographs are in centimeters. 


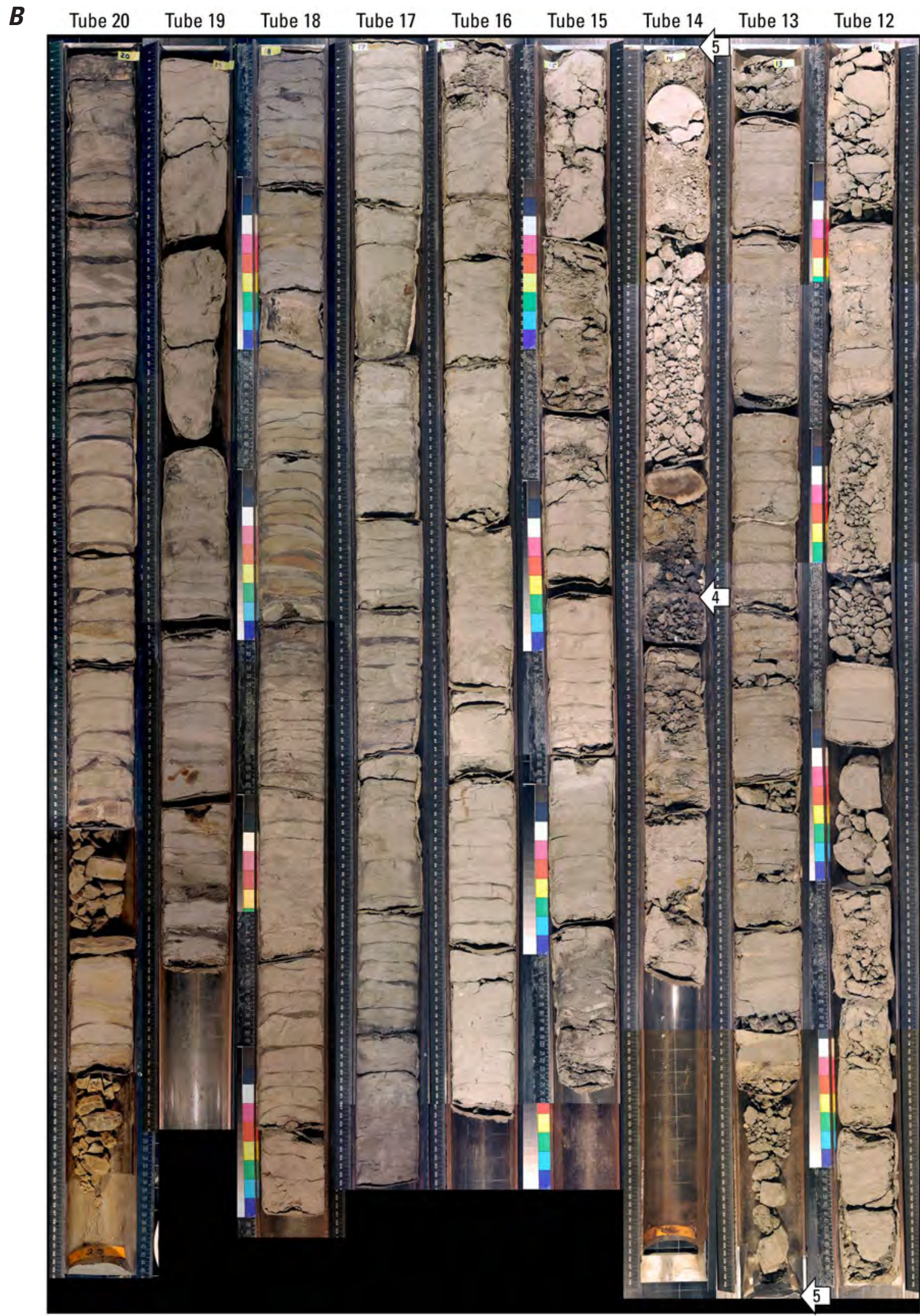

Figure 16.-Continued. 


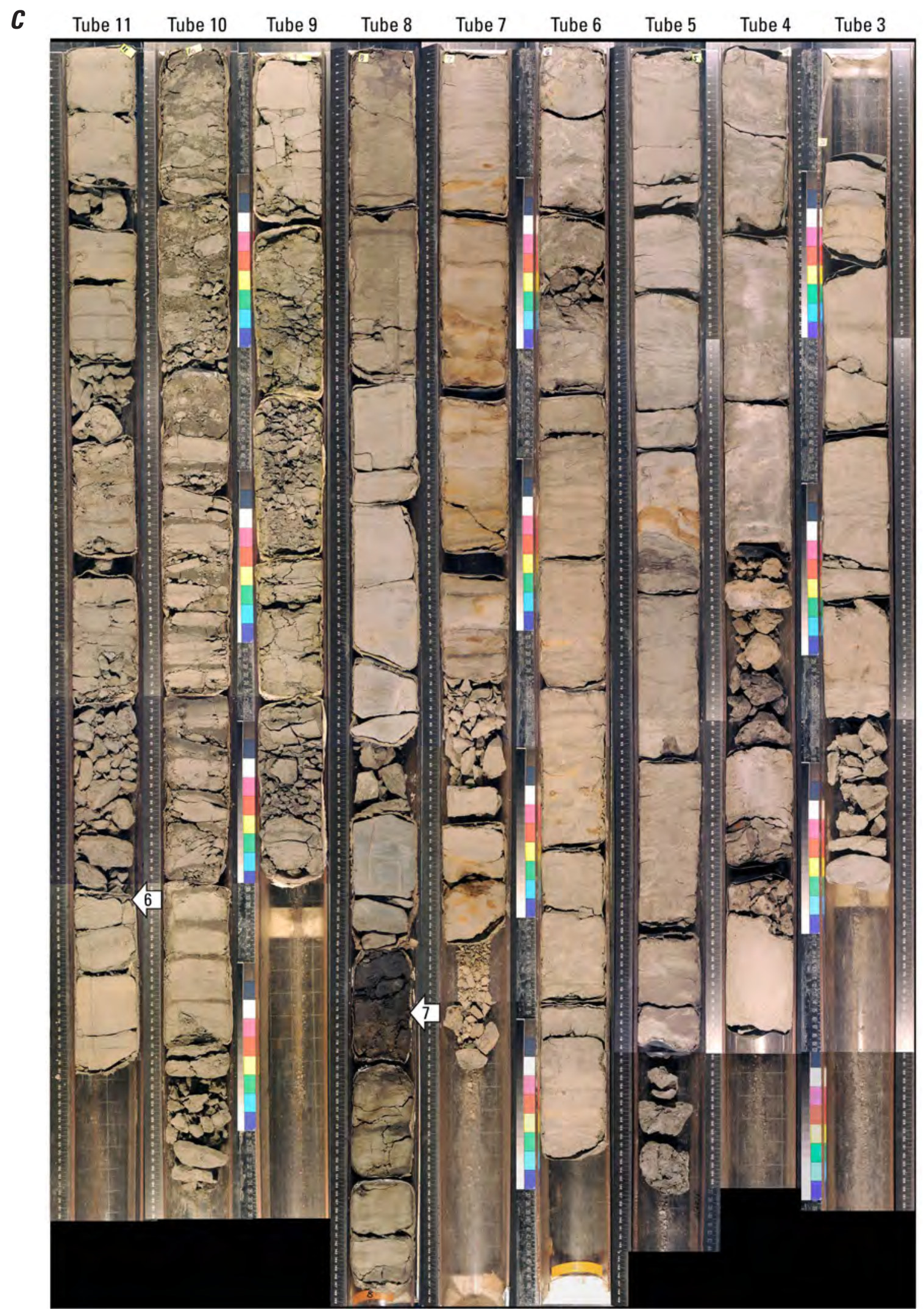

Figure 16.-Continued. 


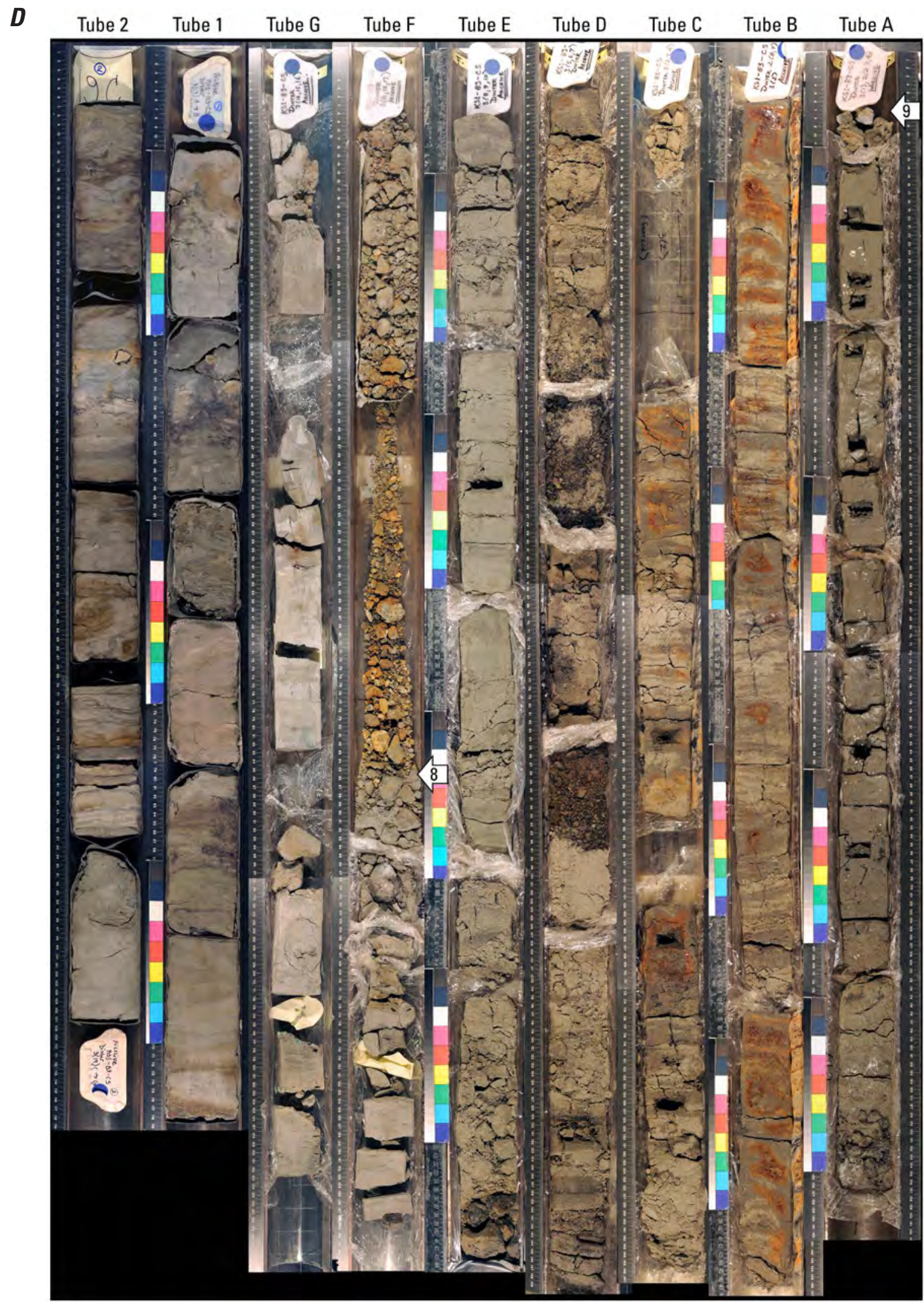

Figure 16.-Continued. 
Table 1. Total organic carbon and Rock-Eval data and summary of vitrinite and bitumen reflectance data and of optical observations for samples from U.S. Geological Survey rotary cores C3 and C7, Chukchi Shelf, Alaska.

[Leco TOC, total organic carbon (weight percent) determined using a Leco carbon analyzer. Rock-Eval, Rock Eval pyrolysis is standard method used to identify the type and maturity of organic matter in sedimentary rocks. S1, volatile hydrocarbon (HC) content (mg HC/g rock); S2, remaining HC generative potential ( $\mathrm{mg} \mathrm{HC} / \mathrm{g}$ rock); $\mathrm{S} 3$, carbon dioxide content ( $\mathrm{mg} \mathrm{CO}_{2} / \mathrm{g}$ rock). Tmax, temperature at which maximum rate of $\mathrm{HC}$ generation occurs in sample during pyrolysis. $\mathrm{HI}$, hydrogen index $=\mathrm{S} 2 \times 100 / \mathrm{TOC}(\mathrm{mg} \mathrm{HC} / \mathrm{g}$ TOC); OI, oxygen index $=\mathrm{S} 3 \times 100 / \mathrm{TOC}$ (mg CO$/ \mathrm{g}$ TOC); PI, production index=S1/(S1+S2); nv, no valid result because of low TOC or high thermal maturity. $\mathrm{mg}$, milligram; g, gram; ${ }^{\circ} \mathrm{C}$, degree Celsius]

A. Total organic carbon and Rock-Eval data.

\begin{tabular}{|c|c|c|c|c|c|c|c|c|c|c|c|}
\hline \multirow[t]{2}{*}{ Core } & \multirow[t]{2}{*}{ Sample } & \multirow[t]{2}{*}{ Leco TOC } & \multicolumn{3}{|c|}{ Rock-Eval } & \multirow[t]{2}{*}{$\mathrm{T}_{\max }\left({ }^{\circ} \mathrm{C}\right)$} & \multirow[t]{2}{*}{$\mathrm{HI}$} & \multirow[t]{2}{*}{ 이 } & \multirow[t]{2}{*}{ S2/S3 } & \multirow[t]{2}{*}{ S1/TOC } & \multirow[t]{2}{*}{ PI } \\
\hline & & & S1 & S2 & S3 & & & & & & \\
\hline 3 & $\mathrm{~S} 1$ & 0.60 & 0.03 & 0.10 & 2.03 & nv & 17 & 337 & 0.0 & 5 & 0.23 \\
\hline 3 & $\mathrm{~S} 13$ & 0.26 & 0.00 & 0.01 & 0.04 & nv & 4 & 163 & 0.0 & $\mathrm{nv}$ & $\mathrm{nv}$ \\
\hline 7 & $\mathrm{~S} 30$ & 1.97 & 0.09 & 0.02 & 0.04 & nv & 1 & 21 & 0.0 & 5 & 0.82 \\
\hline
\end{tabular}

B. Summary of vitrinite and bitumen reflectance data and of optical observations.

\begin{tabular}{lll}
\hline Core & Sample & Observations in reflected light \\
\hline 3 & S1 & No in-situ vitrinite; very low reflectance bitumen; recycled vitrinite and inertinite. \\
3 & S11 & No in-situ vitrinite; very low reflectance bitumen; recycled vitrinite and inertinite. \\
3 & S13 & No in-situ vitrinite; recycled vitrinite with reflectance 0.45 to 0.50 percent; sparse bitumen. \\
7 & S30 & No in-situ vitrinite; most organic matter is solid bitumen; one analyst reported reflectance of 1.7 to 2.4 percent, \\
& & and the other reported reflectance of 1.9 to 3.0 percent. \\
\hline
\end{tabular}

The section between 45.0 and $45.8 \mathrm{~m}$ depth (fig. 15 , unit C3-b) consists of tan to greenish gray siltstone and dark gray mudstone, and the entire interval is variably tuffaceous. The more tuffaceous intervals display darker green tint and contain visible flakes of biotite. Even though this interval is damaged by disking and impregnated with drilling mud, dark gray mudstone with primary horizontal laminae is preserved locally. One sample (S13, fig. 15) from unit C3-b was submitted for palynological analysis. The sample contains mainly long-ranging spores that are not age-diagnostic and that indicate deposition in or near lowland swamps. Kerogen from this sample is characterized by TAI of 2-, equivalent to 0.2 to 0.4 percent VR. Rare, reworked specimens of Early Jurassic pollen are characterized by a TAI of 4(about 1.6 percent VR). Sample S13 also was submitted for micropaleontological analysis but yielded no microfauna.

Organic geochemical analysis of one sample (S13) from unit $\mathrm{C} 3-\mathrm{b}$ is summarized in table 1 . Total organic carbon (TOC) content is very low $(0.26)$, hydrogen index (HI) is low (4), and oxygen index (OI) is moderate (163). Vitrinite reflectance analysis did not yield results as insufficient kerogen was identified as in-situ vitrinite to collect reflectance data. Vitrinite particles inferred to be recycled yielded reflectance values between 0.45 and 0.50 percent. These results are consistent with the low thermal maturity inferred from the palynological analysis and indicate that these samples are not of petroleum source-rock quality.

Datable biotite crystals were recovered from a sample of tuffaceous mudstone (S12) from unit C3-b. Six biotite crystals yielded similar plateau ages, which combine to yield an age of $95.12 \pm 0.05 \mathrm{Ma}$ (reported error is 1 standard deviation) for the sample (fig. 17). Considering the clear evidence that the biotite was deposited in water, the late Cenomanian date must be considered a maximum age for the mudstone, as it is possible that the biotite crystals were reworked from older volcanic deposits sometime after the volcanic event and that the tuffaceous mudstone is younger.

The section between 32.8 and $45.0 \mathrm{~m}$ depth (fig. 15, unit $\mathrm{C} 3-\mathrm{c}$ ) is mainly siltstone and mudstone, with some sandstone beds in the lower part. Sandstone in the lower few meters of the interval is thin bedded and very fine grained and mainly displays plane-parallel laminae and ripple-scale cross bedding. It ranges from tan to greenish gray in color. Much of the overlying section grades subtly between siltstone and mudstone, and mudstone is predominant in the upper $2 \mathrm{~m}$. The entire interval is variably tuffaceous, and color ranges from pale gray, to tan, to greenish gray. Where primary sedimentary structures are visible, they are mainly plane-parallel laminae with ripple scale cross bedding present locally. Near vertical, small diameter (1-3 mm), downward tapering features filled with dark gray to black organic matter that appear to be root traces are scattered throughout this interval.

One sample (S19, fig. 15) from unit C3-c was submitted for palynological analysis. The sample contains mainly longranging spores that are not age-diagnostic, and that indicate deposition in or near lowland swamps. Kerogen from this sample is characterized by TAI of 2-, equivalent to 0.2 to 0.4 percent VR. Rare, reworked specimens of Early Jurassic 

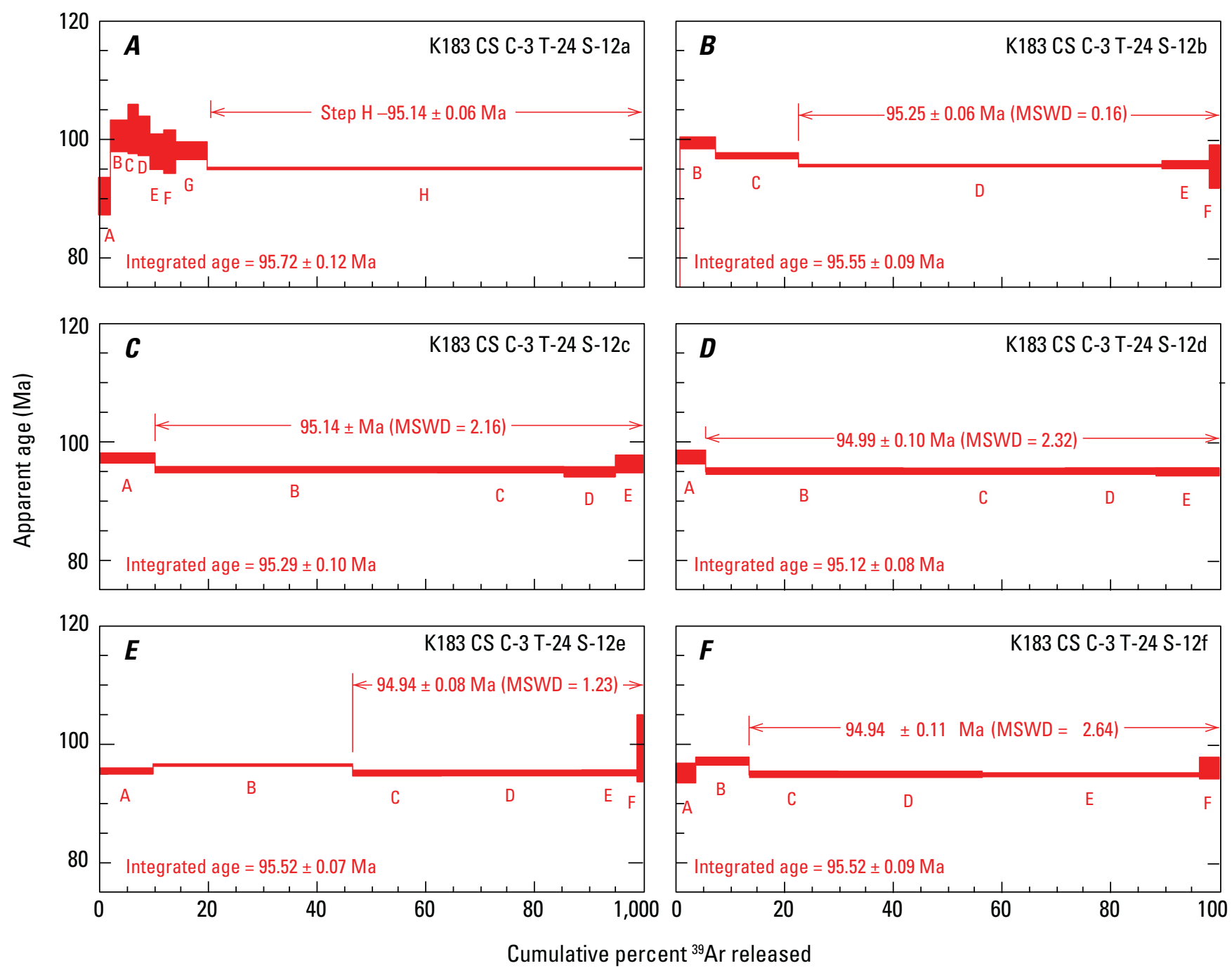

Figure 17. Diagrams of age spectra from argon-40/argon-39 $\left({ }^{40} \mathrm{Ar} /{ }^{39} \mathrm{Ar}\right)$ dating of six single crystals of biotite $(A$ through $F$ from U.S. Geological Survey rotary core C3 tuffaceous mudstone sample S12 (fig. 15, unit C3-b), Chukchi Shelf, Alaska. All biotite crystals share similar spectra and yield a normal distribution of plateau dates that combine to yield an age of $95.12 \pm 0.05 \mathrm{Ma}$ (mega-annum or millions of years ago). Reported errors on ages are 1 standard deviation. MSWD, mean square of the weighted deviates (unitless).

pollen are characterized by a TAI of 4- (about 1.6 percent VR). One sample of tuffaceous sandstone from the lower part of unit C3-c (S14, fig. 15) submitted for ${ }^{40} \mathrm{Ar} /{ }^{39} \mathrm{Ar}$ dating did not yield datable minerals.

Considering that a tephra overlies this interval (fig. 15), we consider unit C3-c as Late Cretaceous in age. The presence of burrows and roots, together with the palynological evidence, suggests deposition in a paludal nonmarine to nearshore shallow-marine setting.

The section between 32.3 and $32.8 \mathrm{~m}$ depth (fig. 15, unit C3-d) is mainly tephra and may include paleosols. At the base of this interval, the top of the underlying mudstone grades upward over $8 \mathrm{~cm}$ into dark gray to black organic material, which in turn grades abruptly upward into a silty, sandy claystone $5 \mathrm{~cm}$ thick with mottled tan, orange, and maroon colors. The claystone is overlain by a large calcareous concretion ( 2 to $4 \mathrm{~cm}$ thick) with a rusty colored interior and white rind (fig. 16). The concretion is abruptly overlain by about $25 \mathrm{~cm}$ of white tephra (partly fragmented by coring), $15 \mathrm{~cm}$ of silty mudstone with tephra fragments, $6 \mathrm{~cm}$ of white tephra as a rounded fragment (coring damage), and $5 \mathrm{~cm}$ of silty mudstone with tephra fragments. One tephra sample from the lower part of unit C3-d (S21, fig. 15) submitted for ${ }^{40} \mathrm{Ar} /{ }^{39} \mathrm{Ar}$ dating did not yield datable minerals.

We interpret the basal part of unit C3-d, capped by the large concretion, as a paleosol developed on the underlying mudstone. Although the overlying tephra did not yield a date, we consider it to be Late Cretaceous in age because of the similarity with dated tephra and tuffaceous rocks elsewhere in this core and in other nearby cores. Considering our interpretation of the basal paleosol, we interpret the tephra to be an air-fall deposit on land. Although the upper part of unit C3-d could be interpreted as one or two paleosols developed on tephra (fig. 16B, section just below arrow 5), we attribute 
the heterogeneous fine grained material that resembles soil to be tephra crushed by coring. Thus, we interpret the interval from the top of the large concretion to arrow 5 to be a single volcanic ash deposited on land (fig. 16B).

The section between 29.8 and $32.3 \mathrm{~m}$ depth (fig. 15, unit $\mathrm{C} 3$-e) is sharp-based sandstone that appears to rest on the MBU within the incision shown in fig. 14. The sandstone is fine grained with widely scattered granules and pebbles. Mudstone rip-up clasts and flakes of organic material are common. Low-angle bedding is common throughout, likely indicating trough cross bedding. The sandstone is mainly medium gray with a common pale green tint. DZ dating of a sample from this sandstone (S22, fig. 15) produced an age spectrum with a distinct young $\mathrm{U} / \mathrm{Pb}$ age population. This young population yields an age of $94.71 \pm 0.35 \mathrm{Ma}$ (late Cenomanian).

Although we interpret unit $\mathrm{C} 3$-e as fluvial sandstone based on texture and sedimentary structures, its age is uncertain. On the one hand, correlation of the core with seismic data suggests that it rests on the MBU. On the other hand, detrital zircon $\mathrm{U} / \mathrm{Pb}$ dating suggests a maximum age of late Cenomanian. We offer three possible interpretations - (1) unit $\mathrm{C} 3$-e rests on the $\mathrm{MBU}$, is Paleogene in age, and the $\mathrm{DZ}$ data reflect zircon grains recycled from Upper Cretaceous strata below the MBU; (2) unit $\mathrm{C} 3$-e rests on the MBU and is a block of Upper Cretaceous strata that slumped from the margin of the incision; (3) the spatial registration between the core and the seismic data is inaccurate, unit $\mathrm{C} 3$-e therefore is below the MBU, and the unit is late Cenomanian as indicated by the DZ data.

The section between 12.2 and $29.8 \mathrm{~m}$ depth (fig. 15, unit C3-f) consists of basal sandstone overlain by thick siltstone. The basal sandstone fines upward over about 2 meters from very fine sand to mudstone. The lower part of the sandstone displays low-angle bedding that may indicate trough cross bedding. It is mainly medium gray in color with a pale green tint locally. The upper part of the sandstone displays disking, fragmentation, and abundant impregnation by drilling mud; this deformation causes much of the section to appear as rubble. However, a couple of coherent disks display ripplescale cross bedding. The remainder of this section is mainly light to medium gray siltstone with a few thin beds of darker gray mudstone and very fine grained, medium gray sandstone (fig. 15). Although core pieces are intact with relatively little coring damage, core recovery in this interval decreases up section so that the stratigraphic record is incomplete between 12.2 and $22.5 \mathrm{~m}$ depth (fig. 15). Nevertheless, an interval between about 15.0 and $19.0 \mathrm{~m}$ depth includes some thin (5 to $10 \mathrm{~cm}$ ) beds of very fine grained sandstone that display ripple-scale cross bedding and flaser bedding. Finer grained facies within this interval include interlaminated siltstone and mudstone that locally display convolute bedding, ironstone rip-up clasts, and patches of orange to dark brown staining.

One sample (S24, fig. 15) from unit C3-f was submitted for palynological analysis. Palynomorphs mainly are longranging and not age-diagnostic, and marine dinocysts are absent. The presence of cool climate pollen combined with the absence of characteristic Paleocene species results in a low confidence, tentative age interpretation of Oligocene. Kerogen from this sample is characterized by a TAI of 1 , which is equivalent to 0.1 percent VR. Reworked palynomorphs are limited to two specimens of Campanian to Maastrichtian dinocysts. We interpret unit $\mathrm{C} 3$-f as Oligocene(?) nonmarine to shallow-marine facies, mainly on the basis of pollen assemblages and the absence of marine microfossils.

The section between 5.0 and $12.2 \mathrm{~m}$ depth comprises a 1-m-thick conglomerate at the base overlain by mainly fine to medium grained sandstone (fig. 15, unit $\mathrm{C} 3-\mathrm{g}$ ). The sharp-based conglomerate is a poorly sorted deposit of chert, quartzite, and sandstone pebbles in a sand matrix. It is buff to gray in color, stained orange, and poorly consolidated. The overlying interval includes two sandstone beds, each between 1.0 and $1.5 \mathrm{~m}$ thick, that fine upward from medium to very fine grained sandstone, and that include millimeter-scale laminae of clay and organic material in the upper several $\mathrm{cm}$. The upper of these two sandstone beds contains two thin (10 to $14 \mathrm{~cm}$ ) intervals with abundant, pebble-sized particles of coaly organic material. Clay laminae and flasers are common in the upper meter. The sandstone is mainly buff to medium gray in color, with local green tint.

Although age is uncertain, we interpret unit C3-g as Neogene(?) or Quaternary based mainly on inferred ages of underlying strata and regional stratigraphic relations. We interpret the basal conglomerate as a fluvial deposit given the grain size and sorting in the unit, and the overlying sandstone may range from nonmarine to shallow marine. The thin intervals containing pebble-sized particles of coaly organic material may represent lenses of peat or carbonaceous mudstone.

The top $5.0 \mathrm{~m}$ of the core is characterized by very poor recovery (fig. 15, unit $\mathrm{C} 3$-h). The few segments of core recovered comprise unconsolidated fine to very fine sand and unconsolidated clay. This unit likely is Quaternary shallowmarine or nonmarine deposits, which typically form a veneer of sediment across the region (Hill and Driscoll, 2008).

\section{Core 7}

Rotary core 7, drilled in $49.4 \mathrm{~m}$ of water, reached a total depth of approximately $16 \mathrm{~m}$ below the seafloor (Winters and Lee, 1985). The geologic context of the core is constrained by relatively poor quality, shallow seismic reflection data collected by the USGS in 1980 (fig. 18). The seismic data show shallow strata that onlap an unconformity approximately $14 \mathrm{~m}$ below the seafloor and mainly transparent seismic character below the unconformity. Core 7 is located about 7 kilometers $(\mathrm{km})$ southwest of the Herald thrust fault (fig. 1) and likely includes pre-Brookian rocks sub-cropping the unconformity on the Herald Arch. Strata above the unconformity represent the northern edge of the Hope Basin, which is filled by Eocene and younger strata (Tolson, 1987; Verzhbitsky and others, 2012). 


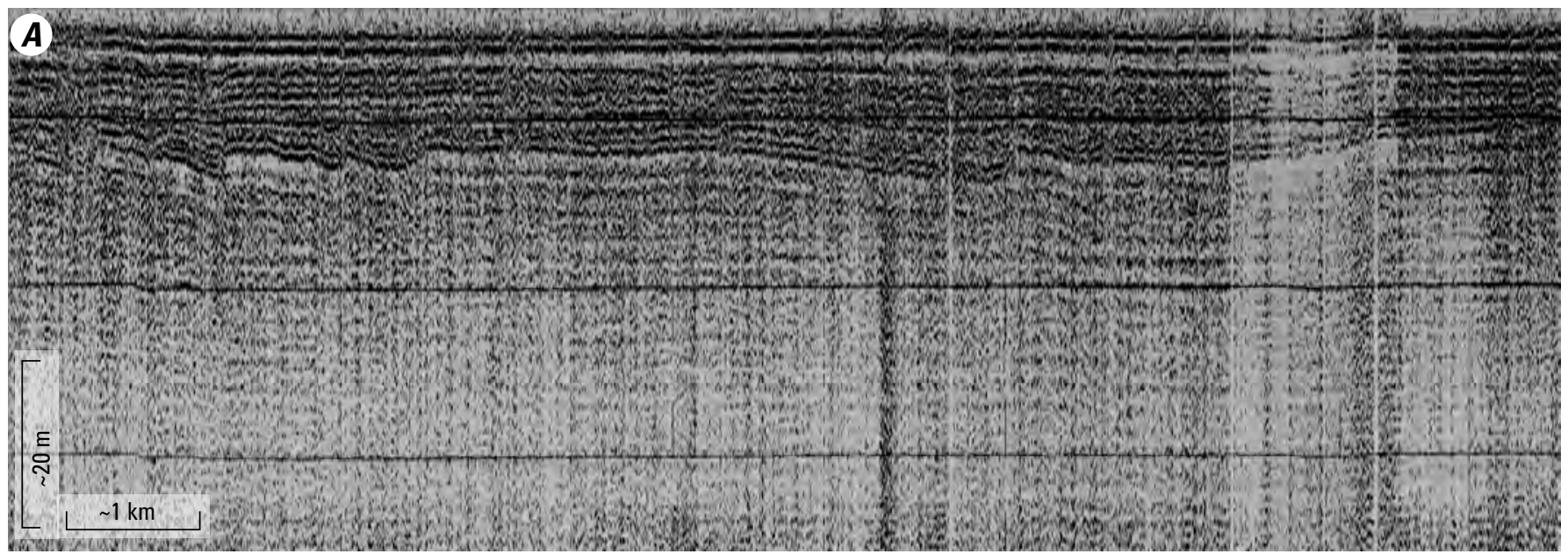
Vertical exaggeration $\sim 40 \mathrm{x}$

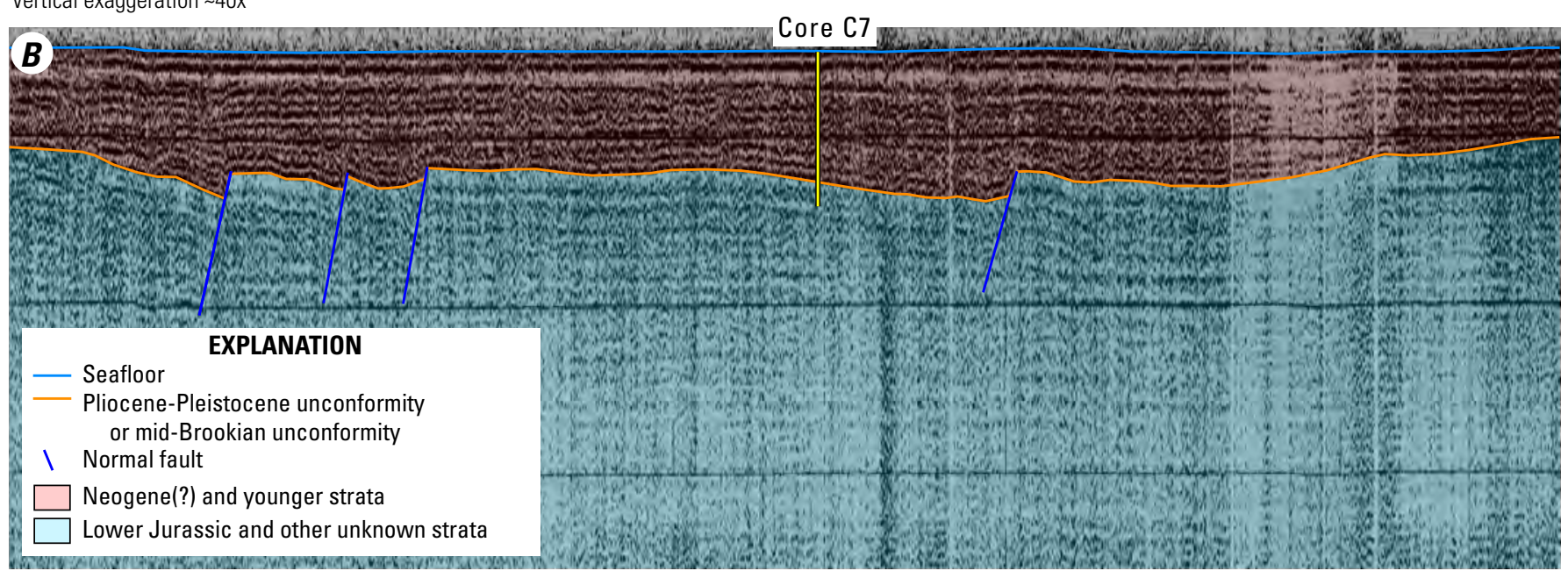

Figure 18. Seismic image across the location of U.S. Geological Survey rotary core C7, Chukchi Shelf, Alaska. Uninterpreted $(A)$ and interpreted $(B)$ uniboom seismic image illustrating unconformity (PPU or MBU) on Lower Jurassic and unknown rocks on Herald Arch. Strata above unconformity are of Neogene(?) and Quaternary age. Normal faults (apparent dip to southwest) offset the unconformity, but no older structures are discernible. See figure 1 for core location. m, meters; km, kilometers.

The bottom $2.3 \mathrm{~m}$ of C7 (unit C7-a, 13.8 to $16.1 \mathrm{~m}$ depth) is severely damaged due to coring, with most of the core fragmented and impregnated by drilling mud (fig. 19). Description of this interval is based on examination of the core and of core fragments following ultrasonic cleaning to remove hardened drilling mud from selected parts of the interval (fig. 20). This entire interval comprises interbeds of very fine to fine grained, medium gray sandstone; medium gray siltstone; and dark gray shale (fig. 19). Neither bed thickness nor sedimentary structures can be described with accuracy. However, one relatively intact bed of dark gray shale is at least 5 to $7 \mathrm{~cm}$ thick and the size of sandstone fragments ( 2 to $5 \mathrm{~cm}$ ) following ultrasonic cleaning suggests a minimum bed thickness around $5 \mathrm{~cm}$.

Three samples of dark gray shale (S30, S31, and S33; fig. 19) were submitted for palynological and micropaleontological analysis. Kerogen (including palynomorphs) in these three samples is poorly preserved because of high thermal alteration, with TAI values of 4 - to 4 , equivalent to 1.6 to 2.0 percent
VR. Identifiable palynomorphs are mainly long ranging and not age-diagnostic. Marine dinocysts are not common but present in all three samples. The dinocysts, together with sparse pollen evidence, indicate an Early Jurassic, likely Toarcian age. Overall, the palynomorph assemblage suggests deposition in a nearshore marine environment, perhaps close to a low-lying coastal plain or lagoon. Microfauna in all three samples consist of tiny (125 to 150 micrometer diameter), agglutinated foraminifera plus unidentifiable bone fragments. The foraminifera, in combination with the palynological data, indicate an Early Jurassic, early Toarcian age for these three samples.

Organic geochemical analysis of one sample (S30) from unit C7-a is summarized in table 1. Total organic carbon (TOC) content is high (1.97 percent), hydrogen index (HI) is very low (1), and oxygen index (OI) is low (21). Vitrinite reflectance analysis did not yield results as insufficient kerogen was identified as in-situ vitrinite to collect reflectance data. Reflectance of particles interpreted to be solid bitumen 


\section{Rotary core K183CS-7}

Location: $69.63168^{\circ} \mathrm{N} ; 168.86308^{\circ} \mathrm{W}$

Water depth: $49.4 \mathrm{~m}(162.1 \mathrm{ft})$

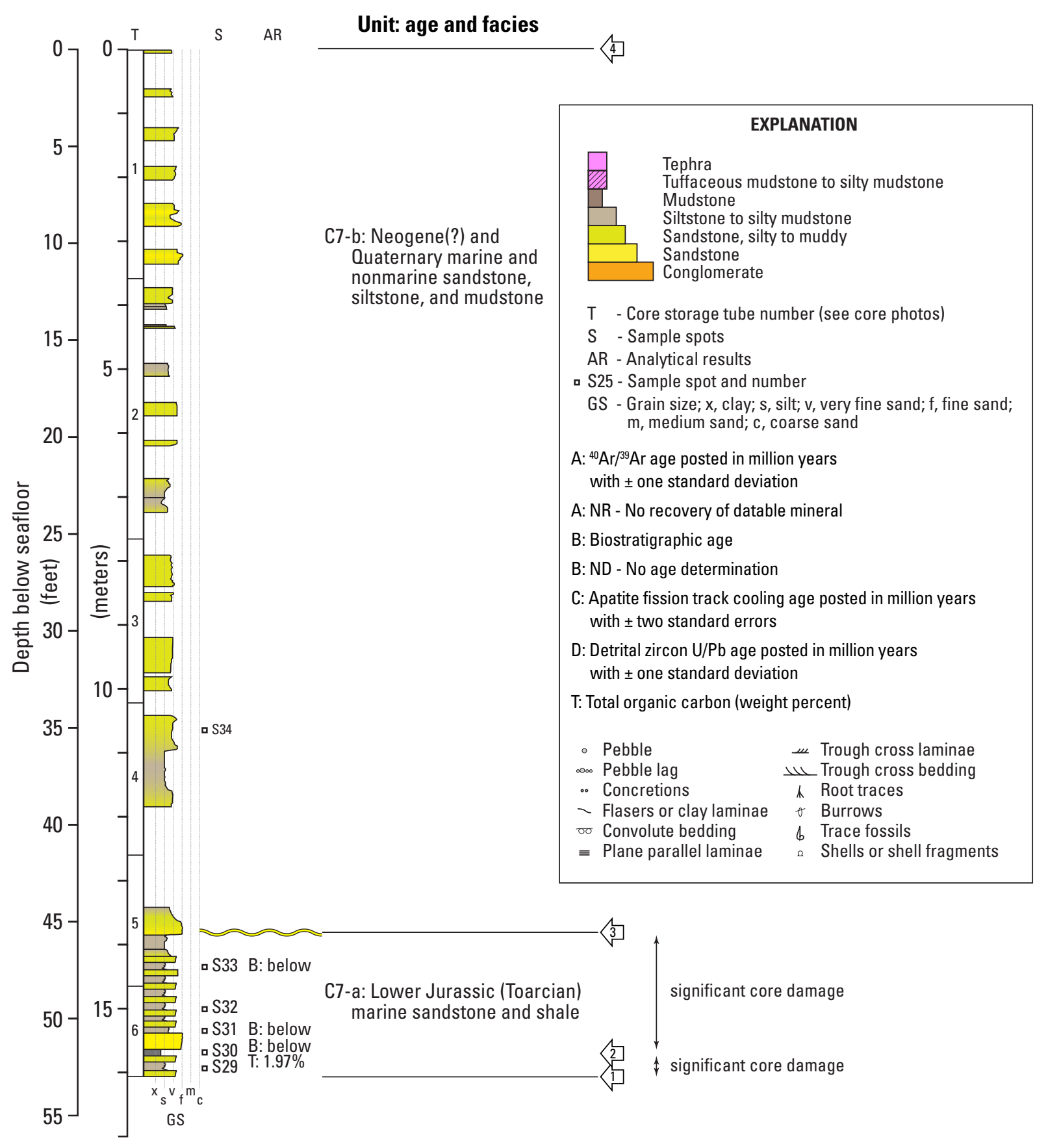

Samples S30, S31, and S33 biostratigraphy: integrated palynology and micropaleontology indicate Early Jurassic (early Toarcian) age; kerogen thermal alteration index (TAI) is 4- to 4, which correlates to 1.6 to 2.0 percent vitrinite reflectance

Figure 19. Graphic section of U.S. Geological Survey rotary core 7C, Chukchi Shelf, Alaska. Top of Lower Jurassic strata indicated by yellow and black unconformity symbol. Numbered arrows correlate to composite core photograph in figure 20. See figure 1 for core location. Note that explanation applies to all related figures in this report. $\mathrm{ft}$, feet; m, meters; ${ }^{40} \mathrm{Ar} /{ }^{39} \mathrm{Ar}$, argon-40/argon-39. 

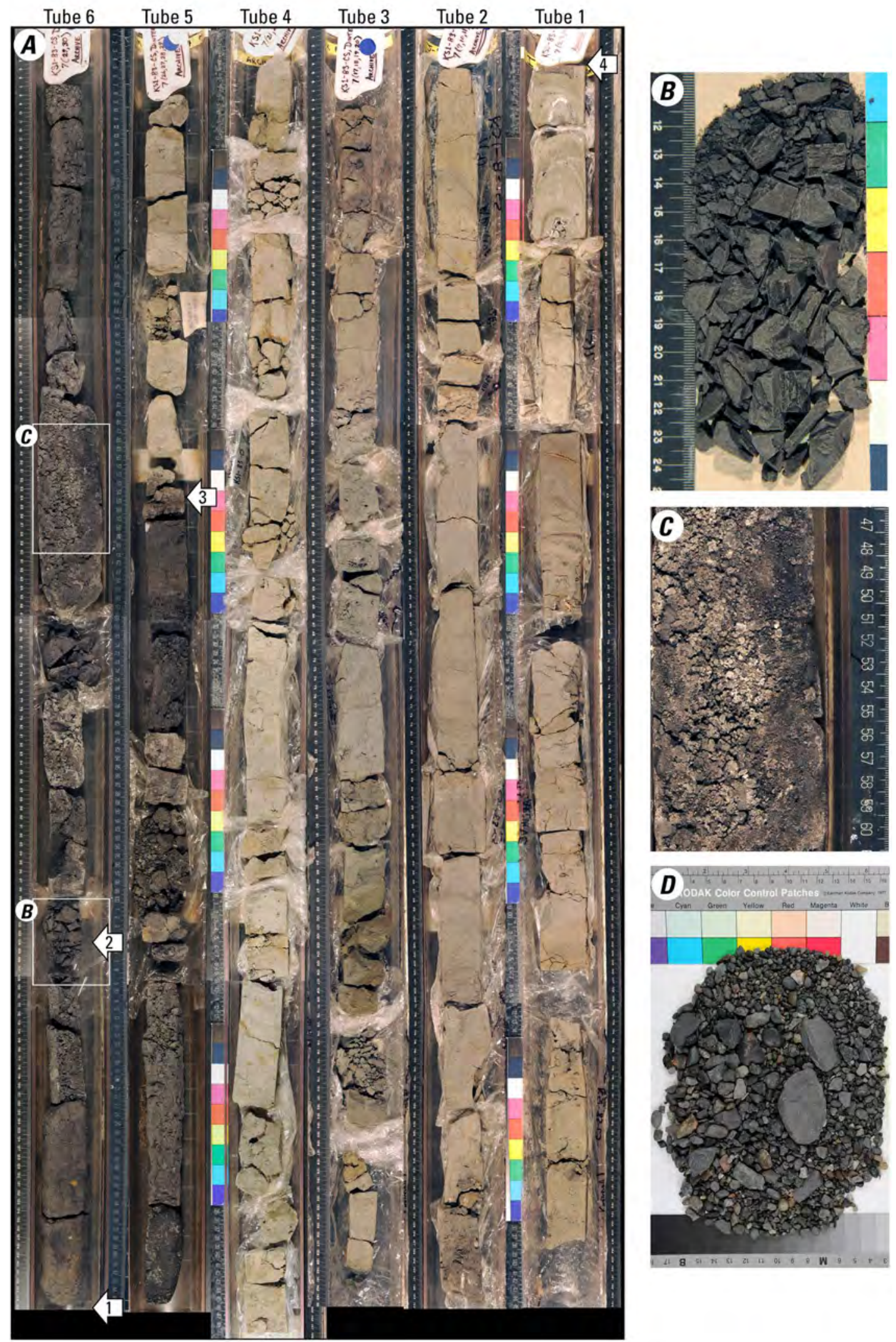

Figure 20. Photographs of U.S. Geological Survey rotary core C7, Chukchi Shelf, Alaska. A, composite photograph; numbered arrows correlate to graphic section in figure 19. $B$, Close up view of Lower Jurassic dark gray shale; location shown by white rectangle labeled with white circle " $B$ " in $A$. $C$, Close up view of fragmented and drilling mud-impregnated core; location shown by white rectangle labeled with white circle " $C$ " in $A$. $D$, Residue of sample shown in $C$ following ultrasonic cleaning in distilled water; largest fragments are very fine to fine grained sandstone. Scales on photographs are in centimeters. 
was measured by two analysts; one reported reflectance of 1.7 to 2.4 percent, and the other reported reflectance of 1.9 to 3.0 percent. These results are consistent with the high thermal maturity inferred from the palynological analysis. The TOC content suggests that this shale originally would have been of petroleum source-rock quality, although whether it was originally oil- or gas-prone is impossible to infer because of the elevated thermal maturity.

Although the remainder of C7 (unit C7-b, 0 to $13.8 \mathrm{~m}$ depth) is mainly segments of whole core, only about half the penetrated section was recovered. The graphic section depicts core segments in depth positions determined by core barrel labels (fig. 19), but there is no way to determine the lithofacies of nonrecovered intervals nor spatial or lithofacies relations between adjacent segments of recovered core. The recovered core suggests that the entire interval consists of interbedded sandstone, siltstone, and mudstone. Sandstone is mainly very fine to fine grained and medium gray to brown in color, with local green tints. Siltstone and mudstone ranges from buff to medium gray in color, with local green tints. Mudstone commonly displays shrinkage cracks parallel to the long axis of core, suggesting that it was not lithified at the time of coring and subsequently has become desiccated. The regional stratigraphic framework suggests these strata may range from Neogene through Quaternary in age, and lithofacies suggest they may include shallow-marine and nonmarine deposits.

\section{Discussion}

\section{Herald Arch Foreland-Cores C3, C53, C65, C67, and C62}

A variety of evidence from cores C3, C53, C65, C67, and C62 indicates the presence of Upper Cretaceous strata across a broad area (150 km from C3 to C62) of the Chukchi Shelf south of the Klondike well (fig. 1, table 2). All five cores contain tephra or tuffaceous lithofacies (figs. 4, 6, 8, 11, and 15), and radiometric dates suggest that volcanic ashes range in age from Cenomanian to Coniacian. This range of ages is consistent with biostratigraphic interpretations from three cores, published K-Ar dates from biotite from one core (Phillips and others, 1988), detrital zircon U/Pb young age populations from three sandstone samples from two cores, and detrital zircon $\mathrm{U} / \mathrm{Pb}$ young age populations from a low thermal maturity sandstone sample with an apatite fissiontrack cooling age interpreted as either volcanic or sediment provenance age (table 2). In addition, biostratigraphic analysis documents the presence in one core of recycled Campanian to Maastrichtian palynomorphs in Oligocene(?) strata (table 2).

These results, together with the inferred presence of Upper Cretaceous strata along the Kuk, Kaolak, and Kukpowruk Rivers onshore (fig. 1; Langenheim and others, 1960; Smiley, 1966, 1969; Spicer and Herman, 2010), suggest that Upper Cretaceous strata are more widely distributed across the western part of Arctic Alaska than previously thought. Considering that Upper Cretaceous strata are widespread in outcrop and the subsurface east of about $155^{\circ}$ W. longitude (fig. 1), it seems likely that Upper Cretaceous strata were present across all of Arctic Alaska before Late Cretaceous or Cenozoic erosion.

Upper Cretaceous strata occur beneath a significant unconformity in each of the five cores discussed above. Upper Cretaceous strata in core $\mathrm{C} 3$ are truncated by the $\mathrm{MBU}$, which is a subtle angular unconformity at this location. Shallow seismic data show that Upper Cretaceous strata beneath the unconformity dip $1-2^{\circ}$ to the north, whereas Paleogene strata above the unconformity are approximately horizontal. This relation documents regional deformation during the Late Cretaceous or Early Paleogene, which is consistent with the results of AFT analysis (Craddock and Houseknecht, 2016). Upper Cretaceous strata in cores C53, C65, C67, and C62 are truncated by the PPU, based on age estimates of strata above the unconformities by Elias and others (1992) and by data presented herein. At each of these core locations, shallow seismic data show the PPU to be a subtle angular unconformity. Onshore, Upper Cretaceous strata are truncated by the MBU, PPU, or modern erosion surface in eastern National Petroleum Reserve in Alaska (NPRA) and along the Kuk, Kaolak, and Kukpowruk Rivers farther west. Upper Cretaceous strata are absent across much of the western North Slope (west of about $155^{\circ} \mathrm{W}$; f fig. 1), perhaps owing to uplift during the latest Cretaceous to early Cenozoic (Houseknecht and others, 2011) or to widespread Quaternary erosion related to glaciation.

Interpretation of depositional facies in Upper Cretaceous strata of the Chukchi Shelf is limited by core damage and incomplete core recovery. Sedimentary structures, together with biostratigraphic interpretations, suggest that deposition ranged from low-lying coastal plain to muddy, shallow-marine environments near shore. The range of depositional settings likely is similar to those inferred for Upper Cretaceous strata exposed onshore in the eastern NPRA (fig. 1; Flores and others, 2007; Flaig and others, 2011, 2013; van der Kolk and others, 2015).

Although the results of this study provide new information regarding the presence, spatial distribution, age, and depositional environments of Upper Cretaceous strata on the Chukchi Shelf, they do not reveal the overall thickness of those strata or the nature of the stratigraphic relation with the Nanushuk Formation. Enhanced knowledge of those topics awaits integration of this work with deeper datasets, including multichannel seismic-reflection and well data.

\section{Herald Arch-Core 7}

The presence of Lower Jurassic marine strata (table 2) beneath a Neogene or younger unconformity on the Herald Arch is significant for understanding the stratigraphic and structural framework of the region. An unpublished, but 
Table 2. Summary of age constraints indicating the presence of Upper Cretaceous and older strata, and evidence for recycled palynomorphs in shallow cores from the Chukchi Shelf, Alaska.

[TAI, thermal alteration index; VR, vitrinite reflectance; ${ }^{40} \mathrm{Ar} /{ }^{39} \mathrm{Ar}$, argon-40/argon-39 age; K-Ar, potassium-argon age; DZ, detrital zircon uranium/lead (U/Pb) age; AFT, apatite fission-track age; NR, no recovery of datable material; na, not applicable; Ma, mega-annum or millions of years ago; \%, percent]

\begin{tabular}{|c|c|c|c|c|c|c|c|c|c|c|}
\hline Core & Unit $^{1}$ & Sample & $\begin{array}{c}\text { Biostratigraphic } \\
\text { age in situ }\end{array}$ & $\begin{array}{c}\text { TAI [VR }]^{2} \text { in } \\
\text { situ }\end{array}$ & $\begin{array}{c}{ }^{40} \mathrm{Ar} /{ }^{39} \mathrm{Ar} \\
(\mathrm{Ma})\end{array}$ & $\begin{array}{c}\text { K-Ar (3) } \\
\text { (Ma) }\end{array}$ & $\mathrm{DZ}^{4}$ (Ma) & $\begin{array}{l}\mathrm{AFT}^{5} \\
(\mathrm{Ma})\end{array}$ & $\begin{array}{l}\text { Biostratigraph- } \\
\text { ic age recycled }\end{array}$ & $\begin{array}{l}\text { TAI }[\text { VR }]^{2} \\
\text { recycled }\end{array}$ \\
\hline \multirow[t]{7}{*}{$\mathrm{C} 3$} & $\mathrm{C} 3-\mathrm{a}$ & $\begin{array}{l}\mathrm{S} 1, \mathrm{~S} 3 \\
\mathrm{~S} 8 \\
\mathrm{~S} 11\end{array}$ & $\begin{array}{l}\text { mid-late } \\
\text { Coniacian }\end{array}$ & $1(0.1 \%)$ & & & & & Early Jurassic & 4- $(1.6 \%)$ \\
\hline & $\mathrm{C} 3-\mathrm{a}$ & $\mathrm{S} 10$ & $\begin{array}{l}\text { mid-late } \\
\text { Coniacian }\end{array}$ & & & & $95.8 \pm 1.8$ & & Early Jurassic & \\
\hline & $\mathrm{C} 3-\mathrm{b}$ & $\mathrm{S} 12$ & & & $\begin{array}{c}95.12 \pm 0.05 \\
\quad \text { (biotite) }\end{array}$ & & & & Early Jurassic & \\
\hline & $\mathrm{C} 3-\mathrm{b}$ & $\mathrm{S} 13$ & nondiagnostic & $2-(0.2-0.4 \%)$ & & & & & Early Jurassic & 4- $(1.6 \%)$ \\
\hline & $\mathrm{C} 3-\mathrm{c}$ & S19 & nondiagnostic & $2-(0.2-0.4 \%)$ & & & & & Early Jurassic & 4- $(1.6 \%)$ \\
\hline & C3-e & $\mathrm{S} 22$ & & & & & $94.71 \pm 0.35$ & & & \\
\hline & $\mathrm{C} 3-\mathrm{f}$ & $\mathrm{S} 24$ & Oligocene(?) & $1(0.1 \%)$ & & & & & $\begin{array}{l}\text { Campanian } \\
\text { Maastrichtian } \\
\text { dinocysts }\end{array}$ & na \\
\hline \multirow[t]{3}{*}{$\mathrm{C} 53$} & $\mathrm{C} 53-\mathrm{a}$ & S39 & $\begin{array}{l}\text { mid-late } \\
\text { Coniacian }\end{array}$ & $2-(0.2-0.4 \%)$ & & & & & Early Jurassic & 4- $(1.6 \%)$ \\
\hline & $\mathrm{C} 53-\mathrm{b}$ & S38 & & & & & $95.24 \pm 0.64$ & $103 \pm 8$ & & \\
\hline & $\mathrm{C} 53-\mathrm{c}$ & $\begin{array}{l}\text { S40, } \\
\text { S41 }\end{array}$ & & & NR & & & & & \\
\hline \multirow[t]{3}{*}{ C65 } & C65-a (top) & S37 & & & $89.35 \pm 0.26$ & & & & & \\
\hline & $\begin{array}{l}\text { C65-a } \\
\text { (middle) }\end{array}$ & S36 & & & $89.11 \pm 0.11$ & & & & & \\
\hline & $\begin{array}{l}\text { C65-a } \\
\quad \text { (base) }\end{array}$ & S35 & & & $89.24 \pm 0.07$ & & & & & \\
\hline \multirow[t]{2}{*}{ C67 } & C67-a (top) & na & & & & $92.1 \pm 1.2$ & & & & \\
\hline & $\begin{array}{l}\text { C67-a } \\
\quad \text { (base) }\end{array}$ & na & & & & $95.2 \pm 1.2$ & & & & \\
\hline $\mathrm{C} 7$ & C7-a & $\begin{array}{l}\text { S30, } \\
\text { S31, } \\
\text { S33 }\end{array}$ & $\begin{array}{l}\text { Early Jurassic } \\
\quad \text { (early Toarcian) }\end{array}$ & $\begin{array}{l}\text { 4- to } 4 \\
\qquad(1.6-2.0 \%)\end{array}$ & & & & & none recognized & na \\
\hline
\end{tabular}

${ }^{1}$ Lithofacies unit labeled on graphic section.

${ }^{2}$ Thermal alteration index [approximate equivalent vitrinite reflectance, in percent].

${ }^{3}$ From Phillips and others (1988).

${ }^{4}$ From figure 12.

${ }^{5}$ From Craddock and Houseknecht (2016).

widely circulated biostratigraphic report first documented the presence in this core of foraminifera and palynomorphs interpreted to be of "Early to Middle Jurassic" age (Mickey and Haga, 1984). However, new biostratigraphic data presented here (previous text, fig. 19, and table 2) provide a higher resolution interpretation of unit $\mathrm{C} 7$-a as lower Toarcian marine strata.

At the location of core C7, Jurassic and older strata are absent in the footwall of the Herald thrust fault owing to nondeposition or pre-Cretaceous erosion (Sherwood and others, 2002), and the cored Lower Jurassic strata are from the hanging wall of the Herald thrust fault. Thus, the cored Lower Jurassic strata must have been deposited in a higher accommodation setting south or southwest of the core location, and subsequently emplaced by the Herald thrust fault, which ramped northward over the southern projection of the high-standing Chukchi Platform (Sherwood and others, 2002, their fig. 7). Apatite fission-track analysis of sandstone from the Lower Jurassic strata in core C7 suggests that maximum burial temperature, likely related to structural burial, was attained in the Late Jurassic or Early Cretaceous and that exhumational cooling to near surface temperatures 
occurred rapidly during the middle Cretaceous (Craddock and Houseknecht, 2016). Considering that Aptian-Albian strata in the thrust and fold belt on the north side of the Herald Arch are structurally truncated by the Herald thrust fault (Sherwood and others, 1998, their fig. 13.8), it is likely that thrust uplift of the hanging wall continued into the middle or Late Cretaceous.

TOC of dark gray shale from the Lower Jurassic strata suggest that it originally was of source-rock quality (TOC 1.97 percent), although high thermal maturity precludes estimating whether it was oil- or gas-prone. Measured bitumen reflectance between 1.7 and 3.0 percent correlates to an approximate range of vitrinite reflectance of 1.6-2.9 percent, based on published correlations of empirical data by Schoenherr and others (2007) and Mählmann and Frey (2012). These high levels of thermal maturity, which are consistent with AFT results (Craddock and Houseknecht, 2016), indicate that the Lower Jurassic strata in core C7 were heated through the oil window and well into the dry-gas window (for example, Houseknecht and Spötl, 1993) before uplift on the Herald thrust fault.

Upper Cretaceous strata in cores $\mathrm{C} 3$ and $\mathrm{C} 53$, located in the foreland north of the Herald Arch (fig. 1), contain recycled palynomorphs of Early Jurassic age and high thermal maturity (previous text, figs. 11 and 15, and table 2), which match the age and thermal maturity of Lower Jurassic strata in core C7. This observation suggests that sediment sources during the Late Cretaceous included Lower Jurassic rocks exhumed on the Herald Arch.

\section{Conclusions}

Six shallow cores collected in 1983 and 1985 on the Chukchi Shelf, western Arctic Alaska, recovered preCenozoic strata that provide important constraints on the framework geology of the region. Five cores from the Herald Arch foreland contain Upper Cretaceous strata ranging from Cenomanian to Coniacian in age. These ages are based on biostratigraphic analysis of mudstone, ${ }^{40} \mathrm{Ar}{ }^{39} \mathrm{Ar}$ and $\mathrm{K}-\mathrm{Ar}$ dating of tephra and tuffaceous mudstone or sandstone, $\mathrm{U} /$ $\mathrm{Pb}$ dating of detrital zircon in sandstone, and fission-track dating of apatite in sandstone. Shallow seismic data reveal that Upper Cretaceous strata at each core location are truncated by an angular unconformity, the mid-Brookian unconformity at core $\mathrm{C} 3$ and the Pliocene-Pleistocene unconformity at cores C53, C65, C67, and C62 (fig. 1). Upper Cretaceous strata in all five cores were deposited in a setting that ranged from low-lying coastal plain (nonmarine) to muddy, shallow-marine environments near shore. The results of this work do not constrain the overall thickness of Upper Cretaceous strata or their stratigraphic relation with the Nanushuk Formation.

One core from the Herald Arch contains Lower Jurassic (lower Toarcian) marine strata truncated by a Neogene or younger unconformity. The Lower Jurassic strata include dark gray shale that originally was of source rock quality, but high thermal maturity precludes determination of whether it was oil- or gas-prone. These strata apparently were buried structurally to maximum temperature during the Early Cretaceous and subsequently uplifted on the Herald thrustfault system during the mid to Late Cretaceous. Recycled palynomorphs in Upper Cretaceous strata in two of the foreland cores are of Early Jurassic age and high thermal maturity, suggesting that the exhumed Herald Arch was a sediment source during the Late Cretaceous.

These results, together with published evidence of locally preserved Upper Cretaceous strata onshore near the Chukchi coast of northwestern Alaska, suggest that Upper Cretaceous strata likely were present across all of Arctic Alaska before latest Cretaceous-Cenozoic erosion.

\section{References Cited}

Akinin, V.V., and Miller, E.L., 2011, Evolution of calc-alkaline magmas of the Okhotsk-Chukotka volcanic belt: Petrology, v. 19, p. 249-290.

Bergman, S.C., Akinin, V.V., Decker, John, Miller, Elizabeth, and Layer, Paul, 2006, North Alaska Upper Cretaceous tephra: Eurasian or North American source calderas?: Geological Society of America, Abstracts with Programs, v. 38, no. 5, p. 90-91.

Bromley, R.G., 1996, Trace fossils—biology, taphonomy and applications ( $2 \mathrm{~d}$ ed.): London, Chapman and Hall, $361 \mathrm{p}$.

Cottle, J.M., Kylander-Clark, A.R., and Vrijmoed, J.C., 2012, $\mathrm{U}-\mathrm{Th} / \mathrm{Pb}$ geochronology of detrital zircon and monazite by single shot laser ablation inductively coupled plasma mass spectrometry (SS-LA-ICPMS): Chemical Geology, v. 332333, p. 136-147, doi.10.1016/j.chemgeo.2012.09.035.

Courtney, Bob, 2012, RegJP2000 version 2.0 (freeware for converting scanned seismic images into SEGY format): Geological Survey of Canada, accessed November, 9, 2015, at ftp://ftp.nrcan.gc.ca/gsc/courtney/RegJP2000/RegJP2000. htm.

Craddock, W.H., and Houseknecht, D.W., 2016, CretaceousCenozoic burial and exhumation history of the Chukchi shelf, Arctic Alaska: American Association of Petroleum Geologists Bulletin, v. 100, no. 1, p. 63-100.

Donelick, R.A., O’Sullivan, P.B., and Ketcham, R.A., 2005, Apatite fission-track analysis: Reviews in Mineralogy and Geochemistry, v. 58, no. 1, p. 49-94, doi:10.2138/ rmg.2005.58.3.

Elias, S.A., 2000, Late Pleistocene climates of Beringia, based on analysis of fossil beetles: Quaternary Research, v. 53, p. 229-235. 
Elias, S.A., Short, S.K., and Birks, H.H., 1997, Late Wisconsin environments of the Bering land bridge: Palaeogeography, Palaeoclimatology, Palaeoecology, v. 136, p. 293-308.

Elias, S.A., Short, S.K., and Phillips, R.L., 1992, Paleoecology of late-glacial peats from the Bering land bridge, Chukchi Sea shelf region, northwestern Alaska: Quaternary Research, v. 38, p. 371-378.

Elias, S.A., Short, S.K., Nelson, C.H., and Birks, H.H., 1996, Life and times of the Bering land bridge: Nature, v. 382, p. 60-63.

Flaig, P.P., McCarthy, P.J., and Fiorillo, A.R., 2011, A tidally influenced, high-latitude coastal-plain: the Upper Cretaceous (Maastrichtian) Prince Creek Formation, North Slope, Alaska, in Davidson, S.K, Leleu, S., and North, C.P., eds., From river to rock record-The preservation of fluvial sediments and their subsequent interpretation: Society for Sedimentary Geology (SEPM) Special Publication 97, p. 233-264.

Flaig, P.P., McCarthy, P.J., and Fiorillo, A.R., 2013, Anatomy, evolution, and paleoenvironmental interpretation of an ancient arctic coastal plain: Integrated paleopedology and palynology from the Upper Cretaceous (Maastrichtian) Prince Creek Formation, North Slope, Alaska, USA, in Driese, S.G., Nordt, L.C., and McCarthy, P.J., eds., New frontiers in paleopedology and terrestrial paleoclimatology: Society for Sedimentary Geology (SEPM) Special Publication No. 104, p. 179230 .

Flores, R.M., Myers, M.D., Houseknecht, D.W., Stricker, G.D., Brizzolara, D.W., Ryherd, T.J., and Takahashi, K.I., 2007, Stratigraphy and facies of Cretaceous Schrader Bluff and Prince Creek Formations in Colville River Bluffs, North Slope, Alaska: U.S. Geological Survey Professional Paper 1748, 52 p., http://pubs.usgs.gov/ $\mathrm{pp} / 1748 /$.

Garver, J.I., Soloviev, A.V., Bullen, M.E., and Brandon, M.T., 2000, Towards a more complete record of magmatism and exhumation in continental arcs, using detrital fission-track thermochrometry: Physics and Chemistry of the Earth, v. 25, p. 565-570.

Grantz, A., Holmes, M.L., and Kososki, B.A., 1975, Geologic framework of the Alaskan continental terrace in the Chukchi and Beaufort Seas, in Yorath, C.J., Parker, E.R., and Glass, D.J., eds., Canada's continental margins and offshore petroleum exploration: Canadian Society of Petroleum Geologists Memoir 4, p. 669-700.

Hill, J.C., and Driscoll, N.W., 2008, Paleodrainage on the Chukchi Shelf reveals sea level history and meltwater discharge: Marine Geology, v. 254, p. 129-151.
Houseknecht, D.W., and Bird, K.J., 2004, Sequence stratigraphy of the Kingak Shale (Jurassic-Lower Cretaceous), National Petroleum Reserve in Alaska: American Association of Petroleum Geologists Bulletin, v. 88, p. 279-302.

Houseknecht, D.W., and Bird, K.J., 2011, Geology and petroleum potential of the rifted margins of the Canada basin, in Spencer, A., Gautier, D., Sørensen, K., Stoupakova, A., and Embry, A., eds., Arctic petroleum geology: Geological Society of London Memoir 35, p. 509-526.

Houseknecht, D.W., and Connors, C.D., 2015, Late Jurassic_-Early Cretaceous inversion of rift structures, and linkage of petroleum system elements across post-rift unconformity, U.S. Chukchi shelf, Arctic Alaska, in Post, P.J., Coleman, J.L., Jr., Rosen, N.C., Brown, D.E., Roberts-Ashby, T., Kahn, P., and Rowan, M., eds., Petroleum systems in "rift" basins: Gulf Coast Section SEPM Foundation, Proceedings of the 34th Annual Gulf Coast Section SEPM Foundation Perkins-Rosen Research Conference, Houston, Texas, December 13-16, 2015, 15 p., thumb drive.

Houseknecht, D.W., and Spötl, Christoph, 1993, Empirical observations regarding methane deadlines in deep basins and thrust belts, in Howell, D.G., ed., The future of energy gases: U.S. Geological Survey Professional Paper 1570, p. 217-231, http://pubs.er.usgs.gov/publication/pp1570/.

Houseknecht, D.W., Bird, K.J., and O'Sullivan, P.B., 2011, Constraining the age and magnitude of uplift in the northern National Petroleum Reserve in Alaska (NPRA) - Apatite fission-track analysis of samples from three wells: U.S. Geological Survey Professional Paper 1784-A, 30 p., http:// pubs.usgs.gov/pp/1784/a/.

Hubbard, R.J., Edrich, S.P., and Rattey, R.P., 1987, Geologic evolution and hydrocarbon habitat of the Arctic Alaska microplate: Marine and Petroleum Geology, v. 4, p. 2-34, doi:10.1016/0264-8172(87)90019-5.

Klemperer, S.L., Miller, E.L., Grantz, A., Scholl, D.W., and the Bering-Chukchi Working Group, 2002, Crustal structure of the Bering and Chukchi shelves-Deep seismic reflection profiles across the North American continent between Alaska and Russia, in Miller, E.L., Grantz, A., and Klemperer, S.L., eds., Tectonic Evolution of the Bering Shelf-Chukchi Sea-Arctic Margin and Adjacent Landmasses: Boulder, Colo., Geological Society of America Special Paper 360, p. 1-24.

Kos'ko, M.K., Cecile, M.P., Harrison, J.C., Ganelin, V.G., Khandoshko, N.V., and Lopatin, B.G., 1993, Geology of Wrangel Island, between Chukchi and East Siberian seas, northeastern Russia: Geological Survey of Canada Bulletin, v. $461,101 \mathrm{p}$. 
Kumar, Naresh, Granath, J.W., Emmet, P.A., Helwig, J.A., and Dinkelman, M.G., 2011, Stratigraphic and tectonic framework of the U.S. Chukchi Shelf-exploration insights from a new regional deep-seismic reflection survey: Geological Society, London, Memoir 35, p. 501-508.

Langenheim, R.L., Jr., Smiley, C.J., and Gray, Jane, 1960, Cretaceous amber from the Arctic coastal plain of Alaska: Geological Society of American Bulletin, v. 71, p. 13451356.

Lease, R.O., Houseknecht, D.W., and Kylander-Clark, A.R.C., 2014, Detrital zircon constraints on Arctic Alaska foreland basin evolution-Brookian chronostratigrpahy, clastic progradation, provenance, and orogenic exhumation [abs.]: Geological Society of America Annual Meeting, Paper No. 326-1, https:/gsa.confex.com/gsa/2014AM/webprogram/ Paper247372.html.

Lerand, M., 1973, Beaufort Sea, in McCrossam, R.G., ed., The future petroleum provinces of Canada-Their geology and potential: Canadian Society of Petroleum Geology Memoir 1, p. 315-386.

Mählmann, R.F., and Frey, Martin, 2012, Standardization, calibration and correlation of the Kübler-index and the vitrinite/bituminite reflectance-An inter-laboratory and field related study: Swiss Journal of Geoscience, v. 105, p. $153-170$.

Mickey, M.B., and Haga, Hideyo, 1984, USGS Chukchi Sea core samples: Unpublished report submitted to U.S. Geological Survey by Micropaleo Consultants, Inc., October 3, 1984, 3 p.

Miley, J.M., and Barnes, P.W., eds., 1986, 1985 field studies, Beaufort and Chukchi Seas, conducted from the NOAA ship Discoverer: U.S. Geological Survey Open-File Report $86-202,57$ p., 5 plates.

Moore, T.E., Dumitru, T.A., Adams, K.E., Witebsky, S.N., and Harris, A.G., 2002, Origin of the Lisburne Hills-Herald Arch structural belt-Stratigraphic, structural, and fission track evidence from the Cape Lisburne area, northwestern Alaska, in Miller, E.L., Grantz, Arthur, and Klemperer, S.L., eds., Tectonic evolution of the Bering Shelf-Chukchi Sea-Arctic margin and adjacent landmasses: Boulder, Colo., Geological Society of America Special Paper 360, p. 77-109.

Lisburne Hills-Herald Arch structural belt-Stratigraphic, structural, and fission track evidence from the Cape Lisburne area, northwestern Alaska, in Miller, E.L., Grantz, Arthur, and Klemperer, S.L., eds., Tectonic evolution of the Bering Shelf-Chukchi Sea-Arctic margin and adjacent landmasses: Boulder, Colo., Geological Society of America Special Paper 360, p. 77-109.
Mull, C.G., Houseknecht, D.W., and Bird, K.J., 2003, Revised Cretaceous and Tertiary stratigraphic nomenclature in the east-central Colville basin, northern Alaska: U.S. Geological Survey Professional Paper 1673, 51 p., http:// pubs.usgs.gov/prof/p1673/.

Phillips, R.L., and Colgan, M.W., 1987, Vibracore stratigraphy of the northeastern Chukchi Sea, in Hamilton, T.D., and Galloway, J.P., eds., Geologic Studies in Alaska by the U.S. Geological Survey during 1986: U.S. Geological Survey Circular 998, p. 157-160, http://pubs.er.usgs.gov/ publication/cir998.

Phillips, R.L., Pickthorn, L.G., and Rearic, D.M., 1988, Late Cretaceous sediments from the northeast Chukchi Sea, in Galloway, J.P., and Hamilton, T.D., eds., Geologic Studies in Alaska by the U.S. Geological Survey during 1987: U.S. Geological Survey Circular 1016, p. 187-189, https://pubs.er.usgs.gov/publication/cir1016/.

Schoenherr, Johannes, Littke, Ralf, Urai, J.L., Kukla, P.A., and Rawahi, Zuwena, 2007, Polyphase thermal evolution in the Infra-Cambrian Ara Group (South Oman Salt basin) as deduced by maturity of solid reservoir bitumen: Organic Geochemistry, v. 38, p. 1293-1318.

Sherwood, K.W., 1994, Stratigraphy, structure, and origin of the Franklinian, northeast Chukchi basin, Arctic Alaska plate, in Thurston, D.K., and Fujita, Kazuya, eds., 1992 Proceedings International Conference on Arctic Margins: U.S. Minerals Management Service OCS Studies 94-0042, p. 245-250.

Sherwood, K.W., Craig, J.D., Lothamer, R.T., Johnson, P.P., and Zerwick, S.A., 1998, Chukchi shelf assessment province, in Sherwood, K.W., ed., Undiscovered oil and gas resources, Alaska federal offshore: U.S. Minerals Management Service OCS Monograph MMS, 98-0054, p 115-196.

Sherwood, K.W., Johnson, P.P., Craig, J.D., Zerwick, S.A., Lothamer, R.T., Thurston, D.K., and Hurlbert, S.B., 2002, Structure and stratigraphy of the Hanna Trough, U.S. Chukchi Shelf, Alaska, in Miller, E.L., Grantz, Arthur, and Klemperer, S.L., eds., Tectonic evolution of the Bering Shelf-Chukchi Sea-Arctic margin and adjacent landmasses: Boulder, Colo., Geological Society of America Special Paper 360, p. 39-66.

Smiley, C.J., 1966, Cretaceous floras from Kuk River area, Alaska: Stratigraphic and climatic interpretations: Geological Society of America Bulletin, v. 77, p. 1-14, 1 plate.

Smiley, C.J., 1969, Floral zones and correlations of Cretaceous Kukpowruk and Corwin Formations, northwestern Alaska: American Association of Petroleum Geologists Bulletin, v. 53, p. 2079-2093. 
Spicer, R.A., and Herman, A.B., 2010, The late Cretaceous environment of the Arctic - A quantitative reassessment based on plant fossils: Palaeogeography, Palaeoclimatology, Palaeoecology, v. 295, p. 423-442.

Stone, D.B., Layer, P.W., and Raikevich, M.I., 2009, Age and paleomagnetism of the Okhotsk-Chukotka Volcanic Belt (OCVB) near Lake El'gygytgyn, Chukotka, Russia: Stephan Mueller Special Publication Series, v. 4, p. 243-260.

Tikhomirov, P.L., Kalinina, E.A., Moriguti, T., Makishima, A., Kobayashi, K., Cherepanova, I.Y., and Nakamura, E., 2012, The Cretaceous Okhotsk-Chukotka volcanic belt (NE Russia): geology, geochronology, magma output rates, and implications on the genesis of silicic LIPs: Journal of Volcanology and Geothermal Research, v. 221-222, p. 14-32.

Tissot, B.P., and Welte, D.H., 1984, Petroleum formation and occurrence $(2 \mathrm{~d}$ ed.): New York, Springer-Verlag, 699 p.

Tolson, R.B., 1987, Structure and stratigraphy of the Hope basin, southern Chukchi Sea, Alaska, in Scholl, D.W., Grantz, Arthur, and Vedder, J.G., eds., Geology and resource potential of the continental margin of western North America and adjacent ocean basins - Beaufort Sea to Baja California: Houston, Texas, Circum-Pacific Council for Energy and Mineral Resources, Earth Science Series 6, p. 59-71. van der Kolk, D.A., Flaig, P.P., and Hasiotis, S.T., 2015, Paleoenvironmental reconstruction of a Late Cretaceous, muddy, river-dominated polar deltaic system: Schrader Bluff-Prince Creek Formation transition, Shivugak Bluffs, North Slope of Alaska, U.S.A.: Journal of Sedimentary Research, v. 85, p. 903-936, doi:10.2110/jsr.2015.58.

Verzhbitsky, V.E., Sokolov, S.D., Frantzen, E.M., Little, Alice, Tuchkova, M.I., and Lobkovsky, L.I., 2012, The South Chukchi sedimentary basin (Chukchi Sea, Russian Arctic): Age, structural pattern, and hydrocarbon potential, in Gao, D., ed., Tectonics and sedimentationImplications for petroleum systems: American Association of Petroleum Geologists Memoir 100, p. 267-290.

Walker, J.D., Geissman, J.W., Bowring, S.A., and Babcock, L.E., compilers, 2013, The Geological Society of America geologic time scale: Geological Society of America Bulletin, v. 125, p. 259-272.

Winters, W.J., and Lee, H.J., 1985, Geotechnical properties of samples from borings obtained in the Chukchi Sea, Alaska: U.S. Geological Survey Open-File Report 85-23, $13 \mathrm{p}$. 

Menlo Park Publishing Service Center, California Manuscript approval date December 7, 2015

Edited by James W. Hendley II

Design and layout by Vivian Nguyen 
